William \& Mary Law School

William \& Mary Law School Scholarship Repository

Faculty Publications

Faculty and Deans

Fall 2012

\title{
The Law School Critique in Historical Perspective
}

A. Benjamin Spencer

spencer@wm.edu

Follow this and additional works at: https://scholarship.law.wm.edu/facpubs

Part of the Legal Education Commons, and the Legal Profession Commons

\section{Repository Citation}

Spencer, A. Benjamin, "The Law School Critique in Historical Perspective" (2012). Faculty Publications. 1983.

https://scholarship.law.wm.edu/facpubs/1983

Copyright c 2012 by the authors. This article is brought to you by the William \& Mary Law School Scholarship Repository.

https://scholarship.law.wm.edu/facpubs 


\title{
The Law School Critique in Historical Perspective
}

\author{
A. Benjamin Spencer*
}

\begin{abstract}
Contemporary critiques of legal education abound. This arises from what can be described as a perfect storm: the confluence of softness in the legal employment market, the skyrocketing costs of law school, and the unwillingness of clients and law firms to continue subsidizing the further training of lawyers who failed to learn how to practice in law school. As legal jobs become increasingly scarce and salaries stagnate, the value proposition of law school is rightly being questioned from all directions. Although numerous valid criticisms have been put forth, some seem to be untethered from a full appreciation for how the current model of legal education developed. Indeed, a historical perspective on legal education is sorely missing from this debate, as many of the criticisms merely echo charges that have been lodged against legal education for well over a century, but do not draw lessons from how those former critiques ultimately failed to deliver fundamental change. This Article reviews the historical development of legal education in America, including the critiques and reforins made along the way, to gain insight that will inform our own efforts to make law schools better at preparing lawyers for practice.
\end{abstract}

* Associate Dean for Research, Frances Lewis Law Center Director \& Professor of Law, Washington and Lee University School of Law; Chair, Virginia State Bar Section on the Education of Lawyers. Copyright (C) 2012 A. Benjamin Spencer. This Article was written during my time as a Visiting Professor at the University of Virginia School of Law, which I would like to thank for its generous grant assistance that enabled this research and for the wonderful research assistance provided by its reference librarians. I would also like to thank those who were able to give helpful comments on the piece, including participants of a workshop on this piece at the University of Virginia School of Law and the Cardozo School of Law. 


\section{Table of Contents}

I. A Perfect Storm .................................................. 1951

II. From Blackstone to Langdell .................................... 1960

A. Private Reading and Office Apprenticeships.......... 1961

B. Professorships in Law .........................................1964

C. The Litchfield Law School....................................1966

D. University Law Schools ......................................1968

E. Langdell and the Modern American Law School.................................................................. 1973

1. The Case Method ............................................1973

2. The Cloistered Law Professor .......................... 1975

3. The Socratic Method.......................................1977

4. Other Reforms ............................................1978

5. Spreading the Langdellian Model ....................1979

III. Over a Century of Critique and Reform......................1982

A. Early ABA Reports .............................................1982

B. The Redlich and Reed Reports on Legal Education............................................................ 1988

C. Twentieth Century Critiques and Reforms ...........2001

D. Contemporary Critiques.....................................2009

IV. The Current State of Legal Education .........................2015

A. The Curriculum ...................................................2020

B. The "Signature Pedagogy" of Law School ...............2026

C. Assessment in Law School ..................................22039

D. Law School Faculty ..........................................2047

V. The Next Century in Legal Education........................2054

VI. Conclusion..............................................................2061 


\section{A Perfect Storm}

"The training received by American lawyers to-day has thus become a curious complex. It cannot be understood unless its main features, and the causes that have produced them, are presented in their historical sequence."

-Alfred Zantzinger Reed, $1921^{1}$

Legal education is under attack. ${ }^{2}$ The value of a law degree is being questioned ${ }^{3}$ given the deterioration of the traditional legal job market ${ }^{4}$ and the substantial and growing size of the student

1. Alfred Z. Reed, Training for the Public Profession of the Law: Historical Development and Principal Contemporary Problems of Legal Education in the United States, With Some Account of Conditions in ENGLAND AND CANADA, Bulletin No. 15, at 4 (1921) [hereinafter REED REPORT].

2. See, e.g., John O. McGinnis \& Russell D. Mangas, First Thing We Do, Let's Kill All the Law Schools, WALL ST. J., Jan. 17, 2012, http://online.wsj.com/article/SB1000142405297020463220457712844330685389 0.html (last visited Sept. 11, 2012) (arguing that state bar associations should work with undergraduate colleges to offer law majors that entitle graduates to take the bar exam, thus removing the need for expensive law schools, lowering legal fees, and increasing the supply of lawyers) (on file with the Washington and Lee Law Review); Martha Nell, 12 More Law Schools Sued Over Reporting of Law Grad Employment and Salary Stats, A.B.A. J. (Feb. 1, 2012, 5:39 PM), http://www.abajournal.com/news/article/12_more_law_schools_sued_in_consume r-fraud_class_action_re_reported_law/ (last visited Sept. 9, 2012) (reporting on lawsuits filed by former law students alleging that schools had falsely advertised post-graduation employment prospects) (on file with the Washington and Lee Law Review).

3. See, e.g., Regrets? Yes. And Money Was the Root of Them All, N.Y. TIMES (Oct. 20, 2010, 12:22 PM), http:/icityroom.blogs.nytimes.com/2010/10/20/regretstheyve-had-a-few-dozen/ (last visited Sept. 10, 2012) (quoting one commenter, when asked about a big financial decision they would reverse, who said, "Simple: I would never go to law school. What a complete waste of time and money") (on file with the Washington and Lee Law Review); see also Careared, Comment to id., (Oct. 21, 2010, 9:13 AM)

I regret law school, but more specifically I regret not fully considering the debt I would be facing after law school and weighing that against the prospect of committing my 20 s to paying off that debt. Finding out I had chosen the wrong profession for me was bad enough, but being trapped in that career for many years just to break even was worse.

4. Jobs in the legal services area are disappearing; between September 2010 and September 2011, there was a loss of 3,200 jobs in this sector. See News Release, Bureau of Labor Statistics, Employment Situation News Release, Table B-1 (Oct. 7, 2011), available at http://www.bls.gov/news.release/archives/ empsit_10072011.htm. As of June 2011, of 2010 graduates whose employment 
loan debt of recent graduates. ${ }^{5}$ Further, law schools are being charged with failing to prepare their graduates adequately for practice. ${ }^{6}$ Thus, we have what appears to be a perfect storm ${ }^{7}$ in

status was known, only $68.4 \%$ had jobs requiring bar passage, with only $64 \%$ overall being full-time legal positions. See Press Release, Nat'l Ass'n for Law Placement (NALP), Class of 2010 Graduates Saddled with Falling Average Starting Salaries as Private Practice Jobs Erode 3 (July 7, 2011), available at http://www.nalp.org/uploads/PressReleases/Classof2010StartingSalaryFindings PressRelease.pdf (providing a summary of the employment status of Class 2010 law students).

5. See William D. Henderson \& Rachel M. Zahorsky, The Law School Bubble, 98 A.B.A. J. 30, 30 (2012) ("In 2010, 85 percent of law graduates from ABA-accredited schools boasted an average debt load of $\$ 98,500 \ldots .$. .). Student loan repayment burdens are worse for students graduating from law schools placed at the lower tiers of the U.S. News rankings, as they tend to have median annual income well below graduates of higher ranked schools. See NALP FOUND. FOR L. CAREER RES. \& EDUC. \& AM. B. FOUND., AFTER THE JD: FirST RESUlTS OF A NATIONAL STUDY OF LEGAL CAREERS 42 (2004) [hereinafter NALP, AFTER THE JD] (providing an in-depth study of the legal profession, including demographics, work satisfaction, compensation, professional mobility, and legal education).

6. See, e.g., William R. Rakes, Conclaves on Legal Education: Catalyst for Improvement of the Profession, 72 NOTRE DAME L. REV. 1119, 1119 (1997) ("The practicing bar is demanding that law schools provide more training to prepare graduates to hit the ground running when they enter practice."); John Caher, N.Y. State Bar Asks ABA to Support 'Practice Ready' Law School Education, LAW.COM (Aug. 5, 2011), http://www.law.com/jsp/article.jsp?id=12025095 95910\&slreturn=1 (last visited Aug. 25, 2012) ("Legal education should have more of an emphasis on making sure graduates are ready to practice law .... It is something that has been de-emphasized, and it shows. Our research and our own experience show that graduates are less prepared to practice law.") (on file with the Washington and Lee Law Review); David Segal, What They Don't Teach Law Students: Lawyering, N.Y. Times, Nov. 19, 2011, https://www.nytimes.com/2011/11/20/business/after-law-school-associates-learnto-be-lawyers.html?_r=1\&pagewanted=all (last visited Sept. 11, 2012) ("What they did not get, for all that time and money, was much practical training. Law schools have long emphasized the theoretical over the useful ....") (on file with the Washington and Lee Law Review). Throughout this Article, I will use the phrase "prepared for practice" or "practice-readiness" to refer to students who have sufficient mastery of the specialized knowledge, skills, and values of the legal profession to serve as competent attorneys and counselors without supervision. Thus, practice-readiness is not simply about having the technical skills required for practice but also about having a solid understanding of legal doctrine, acute analytical abilities, and an understanding of the ethical framework within which lawyers must operate.

7. David Thomson uses this phrase to describe the current situation in legal education in which changes in the legal market, dissatisfaction with law schools, and a new generation of students with more technological savvy are combining to make this a critical moment for change. See DAVID I. C. THOMson, 
legal education: Law school graduates are under-employed, overindebted, and under-prepared for practice.

As the economic downturn has forced legal service providers to deliver services with leaner staffs $^{8}$ or outsourced resources, ${ }^{9}$ technology has developed to the point that fewer attorneys are needed to complete many legal tasks than was the case in the past. ${ }^{10}$ For example, artificial intelligence has advanced such that computerized document review has become faster, cheaper, and of a higher quality than traditional human review. ${ }^{11}$ This means that many lost legal jobs, related to discovery work or other legal tasks, may not be coming back. ${ }^{12}$ Additionally, law firms and

Law School 2.0: Legal Education For a Digital Age 11 (2009).

8. See The Layoff List, THE AM. LAWYER, http://www.americanlawyer. com/PubArticleTAL.jsp?id=1202425647706\&THE_LAYOFF_LIST\&slreturn=20 120726205814 (last visited Aug. 25, 2012) (providing links to news stories about layoffs at law firms across the country) (on file with the Washington and Lee Law Review).

9. See Karen Sloan, Elite Firms Seem to Have Lost Their Appetites, NAT'L LAW J. (Feb. 27, 2012), http://www.law.com/jsp/nlj/PubArticleNLJ.jsp?id= $1202543428334 \&$ slreturn=1 (last visited Aug. 25, 2012) ("Some of that more routine legal work that used to be handled by a lot of associates is now being done by contract attorneys or outside providers.") (on file with the Washington and Lee Law Review); THOMSON, supra note 7, at 16 ("Many corporations send routine legal work to large shops of relatively low-paid attorneys in India. Law firms are doing it too-in a recent study, 80 percent of the largest firms admitted to having outsourced projects.").

10. See Joe Dysart, A New View of Review: Predictive Coding Vows to Cut E-Discovery Drudgery, A.B.A. J. (Oct. 1, 2011, 3:00 AM), http://www.aba journal.com/magazine/article/a_new_view_of_review_predictive_coding_vows_to _cut_e-discovery_drudgery (last visited Aug. 25, 2012) (noting the development of efficient computer software that is capable of conducting document review) (on file with the Washington and Lee Law Review).

11. See, e.g., id. ("Research has shown that, under the best circumstances, manual review will identify about 70 percent of the responsive documents in a large data collection. Some technology-assisted approaches have been shown to perform at least as well as that, if not better, at far less cost.").

12. See Richard SUSSKIND, The END OF LaWyers? REthinking the NATURE OF LEGAL SERVICES 2 (2008)

I argue that the market is increasingly unlikely to tolerate expensive lawyers for tasks (guiding, advising, drafting, researching, problemsolving, and more) that can equally or better be discharged by less expert people, supported by sophisticated systems and processes. It follows, I say, that the jobs of many traditional lawyers will be substantially eroded and often eliminated. 
corporate law departments have recognized that there are some legal tasks that do not necessarily require the same level of training or expertise to complete. ${ }^{13}$ Thus, some firms have established differentiated career tracks that create nonpartnertrack staff attorneys who receive lower compensation for completing more routine and less demanding legal tasks. ${ }^{14}$ Corporate law departments have kept more work in-house with their employees ${ }^{15}$ or used low-paid contract attorneys to do routine legal work. ${ }^{16}$ Two commentators cited statistics predicting that the paucity of legal jobs will be stark going forward, as the American Bar Association (ABA)-approved law schools will be producing roughly 45,000 graduates annually to fill only 25,000 lawyer positions. ${ }^{17}$

13. See Rama Lakshmi, U.S. Legal Work Booms in India, WASH. Post, May 11,2008 , at A20 (noting that in 2008, the legal outsourcing industry had grown "about 60 percent annually" for the past three years because corporate firms outsource work spurred by the passage of e-discovery laws).

14. See Catherine Rampell, At Well-Paying Law Firms, a Low-Paid Corner, N.Y. Times, May 23, 2011, https://www.nytimes.com/2011/05/24/business/ 24lawyers.html?pagewanted=all (last visited Sept. 10, 2012) (describing "twotier" systems in which "permanent associates" earn less than half the pay of traditional associates to do routine legal work as employees of major law firms) (on file with the Washington and Lee Law review).

15. One corporate general counsel reports, "[i]t's simply a situation where, for the most part, law firms have priced themselves out of a whole bunch of work I used to have them do .... If work is going to repeat at all, I'll bring the expertise in-house. My in-house teams have simply gotten much bigger, and my outside counsel use has gone down ...."Jay Pinkert, Straight Talk from General Counsels on How to Win Their Business, ShatTERBox (Feb. 16, 2012), http://www.shatterbox.biz/2012/02/straight-talk-from-general-counsels-on-howto-win-their-business/ (last visited Aug. 25, 2012) (quoting Eric Whitaker, General Counsel of Tesla Motors) (on file with the Washington and Lee Law Review).

16. See Ashby Jones \& Joseph Palazzolo, What's A First-Year Lawyer Worth?, WALL ST. J., Oct. 17, 2011, at B1 ("Of course, the more menial tasks still need to get done. But many corporate legal departments are either farming them to their own employees or giving them to so-called contract attorneys, lower-cost outside lawyers who work independently from the large law-firm ecosystem.").

17. Stanley Fish, Bad News for Law Schools, N.Y. Times (Feb. 20, 2012, 9:00 PM), http://opinionator.blogs.nytimes.com/2012/02/20/the-bad-news-lawschools/\# (last visited Sept. 10, 2012) (on file with the Washington and Lee Law Review); see also Matt Leichter, Clever Plans to Reform Legal Education Won't Make Legal Services Any Cheaper, AmLAW DAILY (Jan. 30, 2012, 12:04 PM), 
This bursting of the legal job market bubble has laid bare two major deficiencies in legal education. First, its costs have risen to levels that could only be sustained as long as cheap student loans and high-paying legal jobs were available, conditions that are now eroding. ${ }^{18}$ Second, the Great Recession has led clients and thus law firms to have less capacity to subsidize the on-the-job training of law graduates ${ }^{19}$ that they had been expected to provide, ${ }^{20}$ revealing deficiencies in the ability of

http://amlawdaily.typepad.com/amlawdaily/2012/01/clever-plans-to-reform-legaleducation-wont-make-legal-services-any-cheaper.html (last visited Sept. 10, 2012) (criticizing suggestions for reform of the legal education system that rest on the assumption that contraction in the legal market is due to the increasing price of legal education, and noting that "actual" employment statistics project a "shallow" legal market in 2018) (on file with the Washington and Lee Law Review).

18. See Nancy M. Jackson, Student Loans Becoming Scarce, Fox Bus. (Sept. 20, 2011), http://www.foxbusiness.com/personal-finance/2011/09/20/ student-loans-becoming-scarce/print (last visited Sept. 10, 2012) ("[T]he money to boost the Pell Grant program was raised by making cuts to the federal student loan program, eliminating the interest subsidy on loans to graduate students for loans after July 1, 2012, and eliminating the Education Department's Direct Loan Program repayment incentives.") (on file with the Washington and Lee Law Review).

19. See Larry E. Ribstein, Practicing Theory: Legal Education for the Twenty-First Century, 97 IowA L. REV. 1649, 1659 ("Law partners who have to spend more time tending to their books of business have less time for building the firm's value through activities like training younger lawyers. Also, increased competition reduces firms' freedom to bill training time to clients."); see also Jones \& Palazzolo, supra note 16 (citing a survey reporting that more than $20 \%$ of responding in-house legal departments refuse to pay for the work of first- or second-year attorneys); id. (quoting the general counsel of a company as saying "Training someone on putting together an asset-purchase agreement shouldn't be done on our nickel"); THOMSON, supra note 7, at 18 ("[F]irms are less and less interested in taking on this role.... [W]ith annual salaries for new attorneys ballooning in some cities to $\$ 150,000$ and more, firms tend understandably to be less patient with new associates who need significant training before they are truly useful.").

20. See Carrie Hempel \& Carroll Seron, An Innovative Approach to Legal Education and the Founding of the University of California, Irvine School of Law, in The PaRAdox OF PROFESSIONALISM: LAWYERS AND THE POSSIBILITY OF JUSTICE 169 (Scott L. Cummings, ed., 2011), available at https://papers. ssrn.com/sol3/papers.cfm?abstract_id=1851702\& ("For the better part of the twentieth century, there has been an informal division of labor between law schools, which are in the business of credentialing knowledge, and first employers responsible for passing on the skills of day-to-day practice."). 
law schools to adequately prepare a sufficient number of their students to handle legal matters for clients. ${ }^{21}$

But this latter critique is not a new development; over the past 130 years we have heard from many sources ${ }^{22}$ that law schools are not truly fulfilling their obligation to prepare students for legal practice. ${ }^{23}$ This would strike many outside the profession as odd since-as Judge Richard Posner once suggested and as most would assume-the "basic focus" of law schools should be "the training of practicing lawyers." 24 This is far from a truism, in

21. See, e.g., N.Y. ST. B. Ass'N, RePort of THE TASK ForCE ON THE FUTURE OF THE LEgal PROFESSION 38 (2011) [hereinafter RePORT OF THE TASK ForCE ON THE FUtURe of THE LEgal PROFEssion] ("Too many law students and recent graduates are not as well prepared for the profession as they might be.").

22. See, e.g., William M. Sullivan, Anne Colby, Judith Welch Wegner, Lloyd Bond \& Lee S. Shulman, Educating Lawyers: Preparation for the PROFEsSion OF LAW 191-92 (2007) [hereinafter CARNEGIE REPORT] ("In the standard model [of law schools], in which cognitive apprenticeship... dominates, the other practical and ethical-social apprenticeships are ... judged as adjuncts to the first."); AM. B. ASS'N SEC. OF LEGAL EDUC. \& ADMISSIONS TO the B., Legal Education and Professional Development-AN EduCational ContinuUm: Report of The TASK Force on Law Schools and the Profession: Narrowing the GaP (1992) [hereinafter MaCCrate Report]; AM. B. Ass'N SeC. OF LEGAL EDUC. AND ADMISSIONS TO THE B., REPORT AND RECOMMENDATIONS OF THE TASK FORCE ON LAWYER COMPETENCY: THE Role OF THE LAW SCHOOLS (1979) [hereinafter CRAMTON REPORT]; REED REPORT, supra note 1.

23. Long ago, Albert Harno, in his 1953 study on legal education in America, noted the criticisms that were leveled at law schools, which, he wrote, "all can be grouped under one heading, that the schools do not adequately prepare students for the tasks they will have to perform in the practice." ALBERT J. HARNo, Legal EdUCATION IN THE UNITED StATES 137 (1953); see also MACCRATE REPORT, supra note 22, at 5 ("[S] urveys understandably indicate that practicing lawyers believe that their law school training left them deficient in skills that they were forced to acquire after graduation."); CRAMTON REPORT, supra note 22, at 8 ("Chief Justice Burger and others have spoken, in recent years, of a serious problem of 'incompetency' among those lawyers trying cases before the federal courts and among the trial bar generally.").

24. Richard A. Posner, The Present Situation in Legal Scholarship, 90 YALE L.J. 1113, 1129 (1981); see also Erwin Chemerinsky, The Ideal Law School for the 21st Century, 1 U.C. IRvine L. REV. 1, 20 (2011) ("[L]aw schools exist preeminently for training students to be lawyers...."). Harno defined the mission of legal education as the production of "well-trained and capable lawyers-lawyers who are skilled in legal procedures, who are versatile in the tasks of the law, who have an understanding and a vision of the purposes and mission of the law, and who are guided by a sense of moral responsibility." HARNO, supra note 23 , at 164 . 
light of the perspective expressed by many that law schools should be primarily scholarly institutions in which the law can be studied and understood as an academic and intellectual pursuit rather than professional schools that provide vocational training. ${ }^{25}$ To be sure, there is ground to allow both perspectives; 26 a law school must train lawyers but also can be "a

25. The late Charles E. Clark, Second Circuit Judge, former Yale Law School Dean, and father of the Federal Rules of Civil Procedure, was a harsh critic of efforts to involve law schools in vocational training in practical legal skills:

I regard the repetitive attempts to coerce law schools into offering socalled practical training as at best curiously naïve, and in general at odds with sound concepts of legal education. Such attempts might be dismissed as a comparatively harmless and not unusual professional baiting of the schools except that law deans and professors are acutely attuned to professional criticism and hence may be led to waste their substance in doing what they cannot do effectively and what if they could would not be pedagogically worth while .... I shall argue that law school training is now effectively efficient... that there is no real basis for the criticism implicit in this pressure for practical training; that the latter is limited, partial and fragmentary at best; and that the present-day legal education in problem analysis and exposition and in thorough documentation of sources is much more important and valuable, as well as more within the practical competence of the schools.

Charles E. Clark, "Practical" Legal Training an Illusion, 3 J. LEGAL Educ. 423, 423 (1951); see also Robert S. Summers, Fuller on Legal Education, 34 J. LEGAL EDUC. 8, 9 (1984) ("Some legal educators today hold that training of practitioners is at most a secondary function of law schools. Rather, the primary function is to create and disseminate new knowledge and understanding about law.").

26. See Thomas Swan, Report of Thomas W. Swan, Dean, to the President and Fellows of Yale University, in RePorts of the PRESIDENT, Acting Provost AND Secretary of Yale University and of the Deans and DiRECTORS OF ITS Several Schools AND DePaRTMENTS FOR THE ACADEMIC YeAR, 1919-1920, at 393 (1920), available at http://books.google.com/books/reader?id=RrNJAAAAYAAJ\& printsec=frontcover\&output=reader\&pg=GBS.PP7 ("A university law school has two functions. It aims by the case method of instruction to train its students so that they may become successful practitioners in their chosen profession. It aims also or at least it should aim, though too few schools have recognized this obligation, to aid in improving the law...."); see also LON L. FULLER ET AL., PReliminary Statement of THE CommitTeE on Legal Education of THE HARVARD LAW SCHOOL 4 (1947) (noting that the two purposes of training lawyers and promoting understanding and improvement of the law "are so closely related that it is unrewarding to discuss which is primary and which is secondary"). 
centre [sic] of research, criticism, and contribution to the better understanding of the laws" with the goal of improving the law. ${ }^{27}$ It is for each school to determine the extent to which it is committed to the latter goal; however, it should be the aim of all to be effective at achieving the former. ${ }^{28}$

Unfortunately, the law school of today is not optimally designed to prepare students for practice. The focus across most of the three years of law school is on teaching legal doctrine, ${ }^{29}$ using principally a method of limited effectiveness, ${ }^{30}$ with too few students being thoroughly instructed in the practice skills and core competencies needed to be a successful lawyer. ${ }^{31}$ These

27. Cecil A. Wright, The University Law Schools, 2 J. LEGAL EDUC. 409, 412 (1950).

28. The ABA Standards require that "a law school... maintain an educational program that prepares its students for admission to the bar, and effective and responsible participation in the legal profession." AM. B. Ass'N, 2012-2013 STANDARDS AND RULES OF PROCEDURE FOR APPROVAL OF LAW SCHOOLS, Standard 301(a) (2012) [hereinafter 2012-2013 ABA STANDARDS AND RULES OF PROCEDURE FOR APPROVAL OF LAW SCHOOLS], available at http://www. americanbar.org/content/dam/aba/publications/misc/legal_education/Standards/ 2012_2013_aba_standards_and_rules.authcheckdam.pdf.

29. See CARNEGIE REPORT, supra note 22, at 3 (noting the concentration of courses on legal doctrine throughout all three years of law school).

30. Critiques of the Socratic case method abound. See, e.g., ROY STUCKEY ET AL., Best PRACTICES FOR LEGAL EdUCATION 112 (2007) ("[T]he Socratic dialogue and case method leaves students confused, teachers often use it poorly, and it contributes to a hostile, competitive classroom environment that is psychologically harmful to a significant percentage of students."); id. at 97-104 (cataloging criticisms of the Socratic method); HARNO, supra note 23, at 138-39 ("One of [the] limitations [of the case method] is the fact that after the first year of law study, there is a distinct lag of interest in the reading of cases on the part of law students. The method by that time has lost much of its sparkle."). The Socratic case-dialogue method will be discussed in greater detail in Part III.B below.

31. See, e.g., David E. Van Zandt, Foundational Competencies, 61 RUTGERS L. REV. 1127, 1136 (2009) ("[N]o school has addressed the core competencies that it takes to be an effective lawyer in a variety of organizations over a multi-job career."). In fact, the practical skills training and experiential learning opportunities that many law schools offer tend to be elective and are taken up in earnest by a minority of law students overall, when compared with the extensive doctrinal instruction all law students receive. NALP FOUND., 2010 SuRvey OF LAW SCHOOL EXPERIENTIAL LEARNING OPPORTUNITIES AND BENEFITS 67 (2011) [hereinafter NALP, 2010 SuRvey OF LAW SchOOL ExPERIENTIAL LEARNING OPPORTUNITIES AND BENEFITS], available at http://www.nalp. org/may2011research_exp_learning?s=2010surveyoflawschoolexperientiallearning 
defects have their origins in the innovations of Christopher Columbus Langdell, the late nineteenth century Dean of the Harvard Law School who envisioned law as a scientific discipline that should be taught by full-time academics using the casedialog method more so than as a craft to be learned by apprentices studying at the feet of experienced practitioners. ${ }^{32}$ Much has changed in law schools since Langdell's time, but to a remarkable degree, much is still fundamentally the same. Appreciating both the legal education system to which Langdell was responding and the nature and rationale of Langdell's various reforms is useful in permitting us to think critically about the basic design of law schools today, especially as we consider how that model should change in response to contemporary challenges.

But why should we care? Members of the bar are rightly giving their attention to this issue, but there are likely some academics who would scoff at the notion that one should concern oneself with this question or that any real problem exists. Whether there is a problem, no one should seriously doubt. ${ }^{33}$ Nor should anyone doubt whether it is for legal academics to devote our attention to this matter; maintaining the quality of the legal education system is vital to any effort to improve the law and the administration of justice. ${ }^{34}$ Furthermore, in an environment

opportumitiesandbenefits (showing $30.2 \%$ of survey respondents had participated in at least one legal clinic, $36.2 \%$ of respondents had taken part in an externship, and $40 \%$ of respondents had taken three or more practice skills courses).

32. See infra Part II.E (discussing Dean Langdell's teaching philosophy towards the law).

33. Of course, there are those who doubt there is a problem. See, e.g., Steven Harper, The Law School Quandary, AMLAw DaIly (Jan. 20, 2012), http://amlawdaily.typepad.com/amlawdaily/2012/01/the-law-school-quandary.html (last visited Sept. 9, 2012) ("If the vast majority of students are happy with the law school experience and changing it won't improve their job prospects, perhaps the legal academy and its critics should consider focusing attention elsewhere.") (on file with the Washington and Lee Law Review).

34. William G. Hammond et. al., Report of the Committee on Legal Education, 14 AM. B. Ass'N REP. 320-21 (1891) [hereinafter Hammond et. al., 14 AM. BAR ASS'N REP.]

No lesson has been more clearly taught by the history of our science from the beginning than that, wherever the law has been best 
where legal jobs are more difficult to attain and the costs and debt associated with legal education are on the rise, allowing the quality of legal education to erode through indifference is a disservice to the students we serve.

Taking the need for reform of some kind to be necessary, the first step in the reform process should be a thorough consideration of what brought us to this point and why our schools take the approach to legal training that they do. Why is law school designed the way that it is today, as a three-year program led by scholars removed from practice focusing on doctrinal legal instruction? What efforts have already been made to move legal education away from that model and why have those efforts failed at achieving any fundamental alteration of how we deliver legal education? What criticisms have been lodged against legal education in the past and what insights might we gain from them for our time? And what suggestions for reform have been made but ignored that could offer ideas whose time may now be ripe? Part II of this Article will plumb some of the history of legal education in this country, while Part III traverses the long line of critiques that have been leveled at legal education. Part IV explores the state of legal education today, with Part $\mathrm{V}$ featuring a discussion of the lessons to be learned from this history for contemporary reform efforts.

\section{From Blackstone to Langdell}

The system of legal education that we have today is the product of an evolutionary process in which subsequent approaches reflect efforts to build on and improve what has come before. This means that law school, as it exists today, is an artifact of its past, with a structure and tradition that is rooted in history more so than being founded on rational design. As a result, although many innovations characterize the modern approach to law school, these adjustments tend to be more

administered and most truly worthy of its high mission, its votaries have been most careful of the education of students and in the statement of its principles, so that such students could thoroughly master them. 
superstructure than substitute, supplementing traditional law school education rather than supplanting it. ${ }^{35}$ As I will argue, however, real and lasting change in legal education requires fundamental rethinking rather than accretive reform. Getting beyond evolution to a revolution in how we educate lawyers, however, requires that we first understand the history that has brought us to where we are. Thus, in this Part and the next, we will review the historical development of formal legal education to its present form to understand the "why" behind the current system, to identify some of the roots of its shortcomings, and to inform our current critique with some of the wisdom and insights from the past.

\section{A. Private Reading and Office Apprenticeships}

"Why disgust and discourage a young man by telling him he must break into his profession through such a wall as this?"

$$
\text { -Daniel Webster, } 1858^{36}
$$

Pre-Revolutionary lawyers in America imported the English common law and with it the rudiments of the English approach to training aspiring lawyers for practice. ${ }^{37}$ This consisted of the office apprenticeship, in which an aspirant was assigned the reading of classic common law texts of varying utility, ${ }^{38}$ and

35. See CARNEGIE REPORT, supra note 22, at 76 ("[T]oday's trend is to supplement rather than replace the inherited reliance on this venerable casedialogue teaching in the first phase of doctrinal instruction.").

36. 1 DANIEL Webster, Biographical Memoir, in The Works OF DANIEL WEBSTER xiii, xxvii (11th ed. 1858) (reflecting on his legal training as an office apprentice, during which he was tasked with reading obscure commentaries on the English common law by Sir Edward Coke).

37. See HARNO, supra note 23, at 27 ("In America, . . . legal education until well past the middle of the 1800's followed the English pattern.").

38. Joseph Story has commented on this phase of his legal preparation, writing that he was told to read Coke on Littleton during his apprenticeship, which he described as "intricate, crabbed, and obsolete learning." JOSEPH STORY, Autobiography, in MiscellaneOUS WRITINGS OF JOSEPH STORY 1, 19 (1852). Story went on to state, "I took [Coke on Littleton] up, and after trying it day after day with very little success, I sat myself down and wept bitterly" but that "[w] hen I had completed the reading of this most formidable work, I felt that I breathed a purer air, and that I had acquired a new power." Id. at 20. Daniel 
placed "at the desk of some skilful [sic] attorney[,] in order to initiate them early in all the depths of practice, and render them more dexterous in the mechanical part of business." ${ }^{39}$ Such preparation was sufficient to become an attorney given the weakness of-or even the absence of-regulations setting forth requirements to practice law during late seventeenth and early eighteenth centuries. ${ }^{40}$ For example, James Flint, an Indiana attorney, wrote in 1819, "Blackstone's Commentaries are considered the great medium of instruction. The young man who has carefully read these, and who has for a short time written for a practicing attorney, is admitted to the bar." 41

The apprenticeship approach to legal education left much to be desired.42 As Blackstone pointed out in his famous Commentaries in remarking on the office apprenticeship:

[A] lawyer thus educated to the bar, in subservience to attorneys and solicitors, will find he has begun at the wrong end. If practice be the whole he is taught, practice must also be the whole he will ever know: if he be uninstructed in the

Webster, who similarly was assigned Coke on Littleton as an apprentice, remarked, "A boy of twenty, with no previous knowledge of such subjects, cannot understand Coke. It is folly to set him upon such an author." WEBSTER, supra note 36 , at xxvii.

39. 1 William Biackstone, Commentaries *32; see also Roscoe Pound, The Law School and the Professional Tradition, 24 MICH. L. REV. 156, 158 (1925) ("[T]raditional ideals of the common-law books and the professional tradition brought over from England by pre-Revolutionary lawyers [were] handed down from lawyer to lawyer in the apprentice training of the old-time law office.").

40. Harno describes the early practice regulations as requiring a number of years of preparation, which did not mean formal legal education at the time, with New Jersey requiring an examination. See HARNO, supra note 23, at 33.

41. Michael H. Harris, The Frontier Lawyer's Library: Southern Indiana, 1800-1850, As a Test Case, 16 Am. J. LEgal. Hist. 239, 241 (1972).

42. The MacCrate Report aptly describes the deficits of the system when it states:

The experienced attorney received cheap labor in exchange for the use of his library, but provided the apprentice with very little in the way of actual legal training. Often, experienced attorneys were too busy practicing law to spend time with their apprentices. There was no guarantee that a skilled practitioner was an adequate teacher. Many apprentices spent their time tediously copying documents for their masters, not studying legal tenets.

MACCRATE REPORT, supra note 22, at 104 (citations omitted). 
elements and first principles upon which the rule of practice is founded, the least variation from established precedents will totally distract and bewilder him. ${ }^{43}$

To that critique, Blackstone added that the apprenticeship model would fail to yield lawyers who could comprehend "arguments drawn a priori, from the spirit of the laws and the natural foundations of justice," and would never attract "a gentleman of distinction or learning" to the bar, leaving it "wholly in] the hands of obscure or illiterate men." 44 Much later, Roscoe Pound would criticize the apprenticeship model on different grounds: that it was ill suited for preparing lawyers in an increasingly urbanized and industrialized America. ${ }^{45}$ In Pound's view, the growing complexity of the economic and social structure that came with industrialization "call[ed] for a deeper and wider training of lawyers than the training in rules of thumb and in procedure which was afforded by the law office." 46 As another twentieth century commentator noted, "That the study of law through mediums of that sort would produce lawyers of limited knowledge and perspective is not a subject for wonder." 47

This is not to say that the office apprenticeship system lacked its advantages. Pound identified certain benefits that were lost with the passage of the apprenticeship approach to academic instruction, including the "handing down of professional traditions from lawyer to lawyer" and "that the law student in his formative days came in contact immediately with the leaders of the bar":

By daily contact he absorbed from them certain traditions, certain ideals of the things that are done and are not done by good lawyers, and a certain feeling as to what was incumbent on him as a member of the profession. We cannot transmit

43. BLACKSTONE, supra note 39 , at * 32 .

44. Id.

45. See Pound, supra note 39, at 159 (describing how industrialization of society shifted the role of lawyers from "the great trial lawyer" to "the steward of the leaders of industry" and thus necessitated knowledge of business as well as law, something that could not be provided solely through the apprenticeship model).

46. Id.

47. HARNO, supra note 23 , at 19-20. 
these things with like efficacy by any system of formal instruction. ${ }^{48}$

Ultimately, however, this approach was not enough; it focused on lawyering as a craft with undue attention to the need for lawyers to have a fuller understanding of the law and the ability to engage in more sophisticated legal analysis in a society of increasing legal complexity.

\section{B. Professorships in Law}

Returning to Blackstone's time, his proposed solution to the deficits of apprenticeship training was to make academic instruction in the law a prerequisite to office-based training. In his words, "The inconveniences [associated with the apprenticeship model] can never be effectually prevented, but by making academical [sic] education a previous step to the profession of the common law, and at the same time making the rudiments of the law a part of academical [sic] education." 49 The creation of professorships in law early in the history of our country within universities was an effort to respond to Blackstone's suggestion and to his example as a professor in law at Oxford.50 The first such professorship was established in 1779

48. Pound, supra note 39, at 160; see also Michael Burrage, From Practice to School-Based Professional Education: Patterns of Conflict and Accommodation in England, France, and the United States, in THE EUROPEAN AND AMERICAN UNIVERSITY SINCE 1800, at 142 (Sheldon Rothblatt \& Bjorn Wittrock eds., 1993) ("[P]rofessional schools often displaced or discredited alternative practice-based forms of professional education. There are, therefore, opportunity costs and another side of its history, the side of the losers, of the viable, traditional institutions directly under the control of practising [sic] professionals.").

49. BLACKSTONE, supra note 39 , at * 32 .

50. See HARNO, supra note 23, at 23 ("One immediate effect traceable to Blackstone's influence was the establishment of chairs of law in several American colleges and universities."); see also Pound, supra note 39, at 160 ("One might say with truth, even if somewhat paradoxically, that American legal education begins with Blackstone's professorship at Oxford."); James Thayer, The Teaching of English Law at Universities, 9 HARV. L. REV. 169, 170 (1895) (describing how "Blackstone's example was immediately followed here [in the United States]" at William and Mary College, Harvard College, and Litchfield Law School). 
at William and Mary and filled by George Wythe. ${ }^{51}$ Aided greatly by Blackstone's Commentaries - which taught early American lawyers "the continuity, the unity, and the reason of the Common Law"52_figures such as St. George Tucker at William and Mary and James Kent at Columbia College taught in the Blackstone tradition and were pioneers in matters of legal scholarship. ${ }^{53}$ These professors were expositors and systematizers of the law, who lectured on legal history, the broad principles that served as the foundation for the law, and the jurisprudence of the day in various subject areas. ${ }^{54}$ Several of these law professorships were established at various American colleges during the late eighteenth and early nineteenth centuries.55 However, legal

51. HARNO, supra note 23, at 23.

52. Charles Warren, A History OF THE AMERICAN BAR 177 (1911) [hereinafter WARREN, A HISTORY OF THE AMERICAN BAR].

53. See HARNo, supra note 23, at 23-26. St. George Tucker based his lectures on Blackstone's Commentaries, supplemented with his own notes on American law. Id. at 23. His notes became the basis for an annotated edition of Blackstone. Id. James Kent also based his lectures on Blackstone and used his lectures as the foundation for his own Commentaries on American Law. Id. at 25.

54. To receive the Royall Professorship in law at Harvard College, the incumbent was required to deliver certain lectures, including:

[T] he theory of law in its most comprehensive sense; the principles and practical operation of the Constitution and Government of the United States... ; an explanation of the principles of the Common Law of England, the mode of its introduction into this country, and the sources and reasons of its obligation therein; also the various modifications by usage, judicial decision, and Statute; and, generally, those topics connected with law as a science which will best lead the minds of students to such inquiries and researches as will qualify them to become useful and distinguished supporters of our free system of government, as well as able and honorable advocates of the rights of the citizen.

1 Charles Warren, History of the Harvard Law School and of Early Legal CONDITIONS IN AMERICA 298 (1908) [hereinafter 1 WARREN, HISTORY OF THE HARVARD LAW SCHOOL] (quoting the statutes of the Royall Professorship); see also id. at 301 (quoting Isaac Parker as saying that "law is a comprehensive system of human wisdom" and, thus, a "science ... worthy to be taught").

55. Other professorships established during this period include the Royall Professorship of law filled in 1815 at Harvard College, a professorship of law at the College of Philadelphia in 1790, a professorship of law at Yale College in 1801, a professorship of law at the University of Maryland in 1816, and a chair of Law and Politics at the University of Virginia in 1826. HARNO, supra note 23, 
education in universities under professors of law was conceived of as "a broad foundation for the further education of prospective lawyers," 56 not as a substitute for training to become a practicing lawyer. ${ }^{57}$ Thus, aspirants to a career as a lawyer remained obliged to pursue an office apprenticeship to be admitted to the bar, ${ }^{58}$ establishing a distinction between academic legal education in colleges and training for practice in law offices. ${ }^{59}$

\section{The Litchfield Law School}

These law professorships did not immediately lead to the development of schools of law within universities as had been hoped. ${ }^{60}$ Indeed, the first established law school, the Litchfield

at $23-24,37-38$.

56. Id. at 27.

57. See Marian Cecilia McKenna, Tapping Reeve and the Litchfield LaW ScHool 59 (Oceana 1986) ("None of these professorships, as the record clearly shows, attempted to offer a complete technical education for law students."); see also Pound, supra note 39, at 160 ("But their lectures were not and were not meant to be professional training in law.").

58. See HARNO, su pra note 23, at 27 ("The educational route to the practice of law was then, as it was to be for some time yet to come, through office apprenticeships, and those who attended these lectures were not relieved from traveling that route."); see also REED REPORT, supra note 1, at 45 ("The special obstacle in northern states [to university based legal education], during these early years, was the still prevailing requirement of a period of clerkship."). Admissions requirements in Virginia during this time were reported to have been weaker than those found in the northern states. See id. at 44 ("In [Virginia] ... the requirements for admission to the bar were already so weak that William and Mary's law department had no difficulty in securing its start at once.").

59. This distinction held for the training of barristers in England at this time, as law professors at Oxford and Cambridge had no hand in their training, which was managed by the Inns of Court-the practitioner "clubs" that oversaw student barristers during their pupilage. See Burrage, supra note 48, at 144-45 ("Oxford and Cambridge professors of law never sought to challenge the Inns' control of the education of the common lawyers. They gave lectures on Roman law, international law, jurisprudence, and constitutional history but hardly referred to the law used by practising [sic] English lawyers.").

60. See James Barr Ames, The Vocation of the Law Professor, in LeCTuRes ON LEGAL HISTORY 354, 359 (1913) ("The hopes that may have been entertained of developing schools of law out of these professorships were in the main doomed to disappointment."). 
Law School in Connecticut, was independent of the university system and arose as an expansion from office apprenticeships in the law office of Tapping Reeve. ${ }^{61}$ This became possible once state bar admissions authorities abandoned efforts to limit the number of apprentices that could study under an attorney at any given time. ${ }^{62}$ The course of instruction offered by Reeve at Litchfield covered all of Anglo-American private law with no special attention given to the law of any one state or to areas of public law. ${ }^{63}$ The weekly Saturday examinations were three hours in length and mainly oral, consisting of "a thorough investigation of the principles of each rule [of law], and not merely of such questions as can be answered from memory without any exercise of the judgement [sic] . . . ."64

An alumnus of the school, James Gould, would later become an associate of Reeve and subsequently shared in the lecturing responsibilities at the school. ${ }^{65} \mathrm{He}$ restructured the curriculum to include topics such as master and servant, bailments, and real property. ${ }^{66}$ It is worth noting that Gould discouraged the reading of cases as the primary means of legal instruction, remarking:

I always dissuade them from reading reports in course, until they have acquired a pretty thorough knowledge of the outline

61. HARNO, supra note 23, at 29.

62. See REED REPORT, supra note 1, at 45 ("What saved the situation ... was the fact that attempts to limit the number of clerks who inight study under one attorney were soon abandoned. This paved the way for the thoroughly natural development of a private attorney's law office into a private class or school ....").

63. MCKENNA, supra note 57, at 63, 65-66.

64. Id. at 85 (quoting CATAlOGUe of The LitchField LAW SCHOOL 5 (photo. reprint) (1900)).

65. Id. at 93 .

66. Id. at 64,108 . Other subjects included municipal law, baron and feme (husband and wife), parent and child, guardian and ward, executors and administrators, sheriffs and gaolers (jailors), contracts, fraudulent conveyances, inns and innkeepers, covenant broken, action of debt, action of account, notice of request, assumpsit, defenses to actions, private wrongs, evidence, systems of pleading, new trials, bills of exceptions, writs of error, practice in Connecticut, bills of exchange and promissory notes, insurance, charter parties, joint owners of vessels, partnership, stoppage in transitu, sailors' contracts, powers of chancery, criminal law, estates upon condition, modes of acquiring estates, devises, title by deed, and actions for injuries to things real. Id. at 64 . 
of the science by studying each principal [subject] separately; being fully convinced that reading in the former mode is of little comparative profit in an early stage of legal studies. ${ }^{67}$

Although the life of this school was only from 1784 to 1833 , it had a remarkable record of producing illustrious graduates. ${ }^{68}$ Its other legacy was to take legal education some degree beyond the office apprenticeship with a more systematic approach to instruction in law, though still occurring nominally in a law office setting. ${ }^{69}$ Other independent schools, though less notable than Litchfield, were in existence during this time as well. ${ }^{70}$ In these schools, we see the attempt to wed academic education and practical training in one setting - the law office rather than the university. This approach, however, would not last.

\section{University Law Schools}

Some of the early holders of law professorships in universities were able to achieve the development of entire law schools within their institutions. Chief Justice Isaac Parker, the first holder of the Royall Professorship in law at Harvard and the leader of the Massachusetts Supreme Judicial Court, was keen for Harvard to found a graduate school to instruct aspiring lawyers in the law before entering "into the office of a counselor to obtain a knowledge of practice."71 Harvard Law School was

67. Id. at 184 .

68. A compendium of alumni by Samuel H. Fisher reports twenty-eight U.S. Senators, 101 members of Congress, thirty-four state supreme court justices, fourteen governors of states and ten lieutenant governors, three U.S. vice presidents, three U.S. Supreme Court Justices, and six members of the Cabinet. HARNO, supra note 23, at 31 .

69. See REED REPORT, supra note 1, at 133 ("The significance of this group of school in our educational development is that they served temporarily to bridge the gap between the students who wished systematized instruction in the law and the colleges that were not yet prepared to give it.").

70. Charles Warren mentions some of these private schools in Virginia, Massachusetts, Connecticut, and Pennsylvania. See WARren, A History of THE AMERICAN BAR, supra note 52, at 364-65. 302

71. 1 WARREN, History OF THE HARVARD LAW SchOOL, supra note 54, at 
founded in 1817, adding Asahel Stearns as a professor. ${ }^{72}$ Although Yale's first professor of law, Elizur Goodrich, ended his nine-year tenure in 1810 without founding a law school there, the head of a private law school in New Haven, Judge David Daggett, was appointed to succeed Goodrich in 1826, bringing his private law school into the College as Yale Law School. ${ }^{73}$ Several other universities soon followed and established law schools, but Harno reports that "[t]hese were not distinguished schools" and "not one that was in operation contemporaneously with the Litchfield School enjoyed at that time the favorable reputation of that School."74

More university law schools were founded throughout the nineteenth century, bringing the number to thirty-one by $1870 .{ }^{75}$ The schools were not offering the three-year law degree of today but rather offered one- to two-year courses of study consisting of lectures and readings of treatises in the areas of law considered important at the time: constitutional law, American jurisprudence, English common law, equity, pleading, evidence, bailments, insurance, bills and notes, partnerships, domestic relations, conflict of laws, sales, and real property. ${ }^{76}$ Liberal education in other topics such as history, philosophy, ethics, and the law of nature, although viewed as important in the effort to produce lawyers of professional excellence, ${ }^{77}$ was presumed to have been obtained elsewhere. ${ }^{78}$ As Harno points out, this presumption was a fallacious one, given that none of the law

72. Id. at 307.

73. See WARREN, A History OF THE AMERICAN BAR, supra note 52, at 364; see also HARNO, supra note 23 , at 38.

74. HARNO, supra note 23 , at 38 .

75. Id. at 51 .

76. 2 WARREN, HiSTORY OF THE HARVARD LAW SCHOOL, supra note 54, at 218 (1908).

77. See JOSEPH STORY, The Value and Importance of Legal Studies, in Miscellaneous Writings of JosePh StORY 503, 529 (1852) ("It is by such studies, and such accomplishments, that the means are to be prepared for excellence in the highest order of the profession.").

78. See id. at 536 ("[T] he course of the academical [sic] instruction in this University already provided for... the subjects of ethics, natural law, and theology, [which were] assigned to other professors."). 
schools established by 1870 required a college education as a prerequisite to admission. ${ }^{79}$

Notwithstanding the development of formalized legal education within the university, the office apprenticeship remained the common method of preparing for a career as a lawyer. ${ }^{80}$ Indeed, Justice Story-upon being inaugurated into the Dane Professorship at Harvard Law School in 1829-confessed, after describing all that would be required to prepare a lawyer for practice, that "[l]ittle, indeed, of what has been sketched out in this discourse, can be attained by any academical [sic] instruction during the usual period assigned for the preparatory studies for the bar .... What we propose is no more than ... something to assist the student in the first steps of his studies...." 81 This reflected the continuing sense that academic legal instruction was only preparatory for and supplemental to apprenticeship learning of the legal craft in law offices. ${ }^{82}$ Further, such limited training was sufficient preparation for the small-scale, local practices that were typical of the profession at the time. ${ }^{83}$

The advances in the formalization of legal education described above were not accompanied by similar advances in the standards for bar admission. To the contrary, as university-based law school education enhanced the intellectual abilities of aspirants to law office apprenticeships, bar admissions standards

79. See HARNo, supra note 23, at 51. Harvard Law School did not require a previous college degree as a prerequisite to admission until 1894, when it announced such a requirement for the class that would enter in 1896 . Id. at $82-$ 83.

80. See id. at 39, 52; LAWREnCE M. FRIEDMAN, A History OF AMERICAN LAW 241 (3d ed. 2005) (noting that by the 1840s, "[f]or most people, the path to practice still went through a clerkship at a lawyer's office"). 532.

81. STORY, The Value and Importance of Legal Studies, supra note 77, at

82. See Burrage, supra note 48, at 152 ("American universities . . . provided law lectures merely as a part of a liberal education as part of the education of a gentleman.").

83. See Harry J. Lambeth, Practicing Law in 1878, 64 A.B.A. J. 1014, 1015-23 (1978) ("Imagine a business world of virtually no telephones[,]. . [n]o typewriters[,] . . . [n]o automobiles[, and] . . . [n]o uniform organized system for legal research .... Instead it was a world of circuit-riding lawyers and storefront, walk-up law offices with brass spittoons, pot-bellied stoves, and overhead gaslights ...."). 
languished and waned under the influence of Jacksonian democratic ideology. ${ }^{84}$ Under this philosophy, screening mechanisms and educational prerequisites were distrusted as obstacles that made law practice accessible only to elites. ${ }^{85}$ The practicing bar thus remained hostile to formal legal education, declining to refine bar admissions requirements to include such education as a prerequisite to being licensed to practice. ${ }^{86}$ This is a skepticism that endured until the late nineteenth century, when the ABA first adopted a resolution calling for each state to require three years of study in law school before applying to sit for the bar examination. ${ }^{87}$ Still, in the early twentieth century, one finds bar examinations that bore little connection to the

84. See Richard P. Cole, Orthodox and Heresy: The Nineteenth Century History of the Rule of Law Reconsidered, 32 IND. L. REV. 1335, 1365 (1999) ("Within the context of the democratic and anti-monopolistic ideology of the Jacksonian period... [p]rofessional legal education markedly declined. Local bar associations no longer set standards of admission for law practice and legislative statutes seemed to make it easier to become a lawyer." (citing DAVID RAY PAKE, HERETICS IN THE TEMPlE: AMERICANS WhO REJECT THE NATION'S LEGAL FAITH (1998))). Jacksonian philosophy also impacted the process by which judges were selected, leading many states to move toward an elected rather than appointed judiciary. See Larry C. Berkson, Judicial Selection in the United States: A Special Report, 64 JudicATURE 176, 176 (1980) ("People resented the fact that property owners controlled the judiciary. They were determined to end this privilege of the upper class and to ensure the popular sovereignty we describe as Jacksonian Democracy.").

85. See HaRivo, supra note 23, at 39 ("It was a period in American history that exalted the rights and powers of the common man .... [T]his creed seemed to hold that all male citizens had the inherent right to practice law.").

86. See id. at 40, 78-79 ("A substantial part of the practicing bar was unconvinced, if not distrustful, of the benefits that might flow to a lawyer through either a university or law school training. This unbelief... stifled efforts to establish educational requirements for admission to the schools and to the bar.").

87. Transactions of the Twentieth Annual Meeting of the American Bar Association, 20 AM. B. Ass'N REP. 31-33 (1897). The language of the adopted resolution was as follows:

Resolved, That the American Bar Association approves the lengthening of the course of instruction in law schools to a period of three years, and that it expresses the hope that as soon as practicable a rule may be adopted in each State which will require candidates for admission to the bar to study law for three years before applying for admission.

Id. at 31 . 
lessons from law school or the needed abilities of a practicing attorney. 88

Thus, from the time of Blackstone through the establishment of university law schools, we can see that formalized legal education was focused on instruction in the English common law and modern American legal doctrine as a foundation for subsequent training in practical skills after law school under the tutelage of practicing attorneys. ${ }^{89}$ No effort was made to attend to the preparatory education students needed before taking up legal studies in universities, nor was any effort made at the university level to train students in practical legal skills. ${ }^{90}$ Academic legal instruction was not developed or designed to serve as a substitute for apprenticeship training in the practical skills of legal practice. ${ }^{91}$ Rather, it was a response to the sentiment reflected by Blackstone that an office apprenticeship by itself was not enough. ${ }^{92}$ In this context, academic legal education and subsequent practical training through apprenticeships were necessary partners in the effort to prepare well-qualified lawyers for practice. It makes sense, then, that with the background understanding that academic and practical training worked in tandem, academic legal education gave no attention to practical skills, focusing purely on instruction in legal principles and doctrines. What remained to be refined was the method to be used for such instruction and the character of those who would be principally called to deliver it.

88. See I. Maurice Wormser, The Results of a Comparative Study of the Examination Questions Framed by State Boards of Bar Examiners, 24 YALE L.J. 34,34 (1914).

89. See supra notes 60-64 and accompanying text.

90. See supra notes 74-79 and accompanying text.

91. See supra note 57 and accompanying text.

92. See supra note 44 and accompanying text. 


\section{E. Langdell and the Modern American Law School}

"I entered upon the duties of my present position ... with a settled conviction that law could only be taught or learned effectively by means of cases in some form."

-Christopher Columbus Langdell, $1871^{93}$

Christopher Columbus Langdell, who became the Dane Professor and Dean at the Harvard Law School in 1870, ${ }^{94}$ was a pivotal figure in the history of legal education in this country. During his time at Harvard Law School, he ushered in several innovations that characterize the modern American law school today.

\section{The Case Method}

The most well-known and enduring innovation Langdell introduced was the instruction of students in legal doctrine through the study of written opinions in decided judicial casesthe case method. Up to this point, the method of legal instruction in law schools was a combination of the lecture method and the text method, meaning students read texts that related and summarized particular bodies of law, and professors lectured on that material in class. ${ }^{95}$ As Theodore W. Dwight, Dean of the Columbia College Law School in New York, explained the method, "The student is assigned daily a certain portion of an approved text-book for his reading prior to listening to expositions of the subject involved .... $[\mathrm{H}] \mathrm{e}$ is asked questions upon the topic . . . . Pertinent illustrations are resorted to . . ."96

93. Christopher C. Langdell, A Selection of Cases on the Law of CONTRACTS, at v (Legal Classics Library ed. 1983) (1871).

94. 1 WARREN, HiSTORY OF THE HARVARD LAW SCHOOL, supra note 54, at 359-60. Warren described Langdell as "a young man of no legal reputation ... . a man of no national fame, and a lawyer who had had substantially no court practice." Id. at 360 .

95. Josef Redlich, The Common Law and the Case Method in American UNIVERSITY IAAW SCHOOLS 7-8, 12 (1914).

96. Theodore W. Dwight, Columbia College Law School, New York, 1 GREEN BAG 141, 145 (1889). 
Such an approach did not jibe with Langdell's view of the law; he firmly believed that law was an inductive science and that the best preparation for a career as a lawyer was to study and master its fundamental principles, not through second-hand accounts but right from the source:

Law, considered as a science, consists of certain principles or doctrines. To have such a mastery of these as to be able to apply them with constant facility and certainty to the evertangled skein of human affairs, is what constitutes a true lawyer; and hence to acquire that mastery should be the business of every earnest student of law. Each of these doctrines has arrived at its present state by slow degrees... in many cases through centuries. This growth is to be traced in the main through a series of cases; and much the shortest and best, if not the only way of mastering doctrine effectually is by studying the cases in which it is embodied. ${ }^{97}$

In these remarks, one can see two important strains of thought that would have a tremendous impact on the development of law school education. First, Langdell's understanding of what it means to be a lawyer-reflected in his comment that "mastery" of "certain principles or doctrines . . . is what constitutes a true lawyer"98_gives rise to his view that the best preparation for practice was to study legal rules-principles and doctrines-rather than learning the skills of legal practicelaw as mere "handicraft." 99 Second, Langdell's understanding of the law-that it was a science whose study would be most effective when focused on examining the sources of legal principles and doctrines-leads to his determination that reported cases must be studied rather than summary expositions of the law contained in texts and treatises. ${ }^{100}$ In other words,

97. LANGDELL, supra note 93, at vi.

98. Id. 374.

99. 1 WARREN, History OF THE HaRVARD LAW SCHOOL, supra note 54, at

100. REDLICH, supra note 95, at 15 ; see also 1 WARREN, HISTORY OF THE HARVARD LAW SCHOOL, supra note 54, at 423 ("The Case System then proceeds on the theory that law is a science and as a science should be studied in the original sources, and that the original sources are the adjudged cases, and not the opinions of text writers based on the adjudged cases."); id. at 421 ("[T]he student must look upon law as a science consisting of a body of principles to be 
Langdell believed that law was a form of natural science in that it consisted of a coherent system of rules derived from general principles that could only be discerned through the study of observable phenomena-the judicial opinions in which the principles were manifested.101 These views of the law and of lawyering supported and furthered the move away from practitioner-based apprenticeship in favor of formal instruction by full-time, legal scholars. ${ }^{102}$

\section{The Cloistered Law Professor}

Indeed, the conversion of the professoriate into cloistered academics, rather than experienced practitioners, was Langdell's next innovation. With law school being characterized by a curriculum focused on doctrinal study, Langdell remarked that "[w]hat qualifies a person, therefore, to teach law is not experience in the work of a lawyer's office, not experience in dealing with men, not experience in the trial or argument of causes-not experience, in short, in using law, but experience in learning law ...." 103 As a result, Langdell took the bold step in the fall of 1873 of hiring an assistant professor who had only graduated from law school two years prior and whose experience was limited to serving as an instructor in French, German, and

found in the adjudged cases, the cases being to him what the specimen is to the geologist." (quoting WILLIAM A. KEENER, A SELECTION OF CASES ON THE LAW OF QUASI CONTRACTS, Preface (1888))).

101. See Edward Rubin, What's Wrong with Langdell's Method and What to Do About It, 60 VAND. L. REV. 609, 632-33 (2007) ("Since Langdell saw this methodology as a means of discerning general, objectively identifiable principles of law, he really seemed to believe that his approach was natural science itself.").

102. See CARnegie Report, supra note 22 , at 5 ("[L]egal positivists... viewed the law as ... a set of rules and techniques rather than a craft of interpretation and adaptation.... All this spelled the eclipse of traditional forms of practitioner-directed apprenticeship by academic instruction given by scholar-teachers.").

103. 1 W ARREN, HISTORY OF THE HARVARD LAW SCHOOL, supra note 54, at 361 (quoting a speech made by Dean Langdell at the dinner of the Harvard Law School Association on November 5, 1886). 
history at Harvard College-James Barr Ames. ${ }^{104}$ Prior to that time, Harvard's law professors had been drawn primarily from the practicing bar. ${ }^{105}$ As Harvard President Eliot explained, however, the idea of hiring young, inexperienced persons to teach law was borrowed from the law schools of Continental Europe:

Those schools have selected young men of mark who have shown a genius for law and a desire for the life of a teacher, and ... made them Professors, at an age so early that the whole vigor of their youth and prime could be thrown into teaching and authorship. 106

President Eliot went on to predict, quite presciently, that this innovation would take hold and fundamentally change the legal academic profession:

Professor Langdell early advocated the appointment, as teachers of law, of young men who had had no experience whatever in the active profession .... Now that experiment... has not only been extended in our own Law School with perfect success but it has been adopted by various other law schools throughout the country.... In due course ... there will be produced in this country a body of men learned in the law who have never been on the bench or at the Bar, but who nevertheless hold position of great weight and influence as teachers of law, as expounders, systematizers and historians. This, I venture to predict, is one of the most far reaching changes in the organization of the profession that has ever been made in our country. ${ }^{107}$

Eliot rejected the analogy to medical school training, in which practitioners are acknowledged to be the best instructors of clinical training, by insisting-as did Langdell-that "law is to be learned almost exclusively from the books in which its principles and precedents are recorded, digested, and explained," and, thus, "[t]he law library, and not the court or the law office, is the real analogue of the hospital." 108 With this vision, the career, legal

104. Id. at 388 (stating that the appointment was an "experiment" and an "important innovation" for the law school).

105. See id.

106. Id. at $388-89$.

107. Id. at 389 .

108. Id. at 391-92. 
professoriate was born, purely academic in character and divorced from the practicing bar.

\section{The Socratic Method}

A critical companion to the case method was another Langdellian innovation: the instructional approach used to discuss the cases with students in class known as the Socratic method. Langdell conducted his own courses using this method, having a student analyze the facts and the law in each case, followed by a series of questions designed to reveal the legal principles to be found therein. ${ }^{109}$ In addition to learning legal doctrine, Langdell's disciples and subsequent adherents have rightly noted that the case-dialogue method was also designed to train students to develop the analytical abilities of a lawyer: "The student is challenged to reconcile discrepancies, to explain conflicts, to pick up the tangled threads of thought where they are left by the decisions and put them in order."110 By employing the dialogue approach to the exploration of cases, the idea was that the case method would not only facilitate the scientific discovery of legal principles from their sources, but it also would contribute to the development of students' ability to engage in legal reasoning, analysis, and synthesis. ${ }^{111}$

109. REDI.ICH, su.pra note 95, at 12. Redlich described the method as:

Teacher and pupils... work[ing] together unremittingly to extract from the single cases and from the combination or contrasting of cases their entire legal content, so that in the end those principles of that particular branch of the law which control the entire mass of related cases are made clear.

Id.

110. HARNO, supra note 23, at 137-38 (quoting the Preliminary Statement of the Committee on Legal Education of the Harvard Law School); see also 1 WARREN, HiSTORY OF THE HARVARD LAW SchOOL, supra note 54, at 421 ("The student is required to analyze each case, discriminate between the relevant and irrelevant, between the actual and possible grounds of decision. And after having thus discussed a case, he is prepared and required to deal with it in its relation to other cases." (quoting WILLIAM A. KEENER, A SELECTION OF CASES ON THE LAW OF QUASI CONTRACTS, Preface (1888))).

111. See William A. Keener, The Inductive Method in Legal Education, 17 AM. B. Ass'N REP. 473, 482 (1894) ("While the student's reasoning powers are being thus constantly developed, and while he is gaining the power of analysis 
The case-dialogue method of instruction was seen as an application of the scientific method to the study of law at a time when American colleges were moving away from a classical approach to higher education toward methods reflected in the modern study of science. ${ }^{112}$ Langdell recognized this trend and the need to conform the study of law to it in order to retain its place within the university: "If law be not a science, a university will best consult its own dignity in declining to teach it. If it be not a science, it is a species of handicraft, and may best be learned by serving an apprenticeship to one who practices it."113 Langdell's contemporary, Harvard Law School Professor William Keener, was more explicit in drawing the connection when he wrote, "[I]f [law] is not a science it has no place in the curriculum of a university."114

\section{Other Reforms}

Langdell was also responsible for several other major reforms that transformed university-based legal education to the model we know today. In 1871, the course of study at the Harvard Law School was extended from eighteen months to two years, a change prompted by the realization that the case method required a longer period of time to be successful than eighteen months could allow. ${ }^{115}$ Strict examinations were introduced as prerequisites to proceeding to the next year of study and to receiving the degree. ${ }^{116}$ These changes, along with the introduction of the case

and synthesis, he is also gaining the other object of legal education, namely, knowledge of what the law actually is.").

112. See REDLICH, supra note 95, at 16 (describing how "the old, strictly classical ideal of college instruction in America" was "yielding in favor of a new theory of education" that was based predominantly on the study of the natural sciences).

113. 1 WARREN, History OF THE HARVARD LAW SchOOL, supra note 54, at 374.

114. Keener, supra note 111 , at 475.

115. See 1 WARREN, History OF THE HARVARd LAW SchoOL, supra note 54, at 379 ("Firm in his belief that law was a science, to be taught and learned as such, Langdell was equally convinced that no student could receive a proper legal education in so short a period as eighteen months.").

116. See id. at 380, 397 (noting that students "shall have passed satisfactory 
method, were initially controversial among the practicing bar, leading to a decline in enrollments compared with the previous decade. ${ }^{117}$ In 1875, an admissions examination was instituted and required of all applicants, beginning in 1877, who lacked prior collegiate education. ${ }^{118}$ Finally, for the $1877-1878$ academic year, Langdell extended the course of study to three years. ${ }^{119}$ Rather than result in a reduction of enrollment, however, these latter two changes were followed by an increase in both the size and quality of the law school's student body. ${ }^{120}$

\section{Spreading the Langdellian Model}

By the early part of the twentieth century, formalized university-based legal education was well established and highly developed compared with the system of legal education in other common law countries. ${ }^{121}$ These law schools were increasingly Langdellian; although Langdell ended his tenure as Dean of the Harvard Law School in 1895, this case method approach to legal

examinations at the end of each year" and that "the whole tone of the School changed from laxity to strictness").

117. See id. at 382,386 ("[T]here was much criticism and even bitter opposition among lawyers ... over the new Case System employed by Professor Langdell. Undoubtedly this kept many students from entering the School.").

118. See id. at 394-95, 399 (noting that in 1875, the school established an admission exam applicable "to all candidates for the of the School who are not already Bachelors of Arts, Science, or Philosophy").

119. Id. at 399 .

120. See id. at 400 ("[T]he prediction... that the establishment of an examination, together with an extension of the course of study from two years to three years, would cause an immediate and material diminution of our numbers, had not thus far been verified.").

121. REDLICH, supra note 95, 5-6. In comparing the advancement of the American legal education system to other common law countries, Redlich noted:

[T] he existing American system of legal education has hardly a rival worth mentioning in the entire great jurisdiction of the English common law. Neither in England itself, nor in the great English colonies, has systematic instruction in law achieved a development so intensive and at the same time so comprehensive as in the United States.

Id. Redlich also reports that in 1914 there were more than 150 American law schools, with over 20,000 students. Id. at 7 n. 1 . 
education was continued by his successor, James Barr Ames. ${ }^{122}$ When William Keener-who had been a Harvard professor under Langdell-joined Columbia's faculty in 1890, he brought the case method with him. ${ }^{123}$ By 1906, the Langdell method had spread to law schools at Chicago, Northwestern, Cincinnati, Stanford, Wisconsin, Hastings, and Tulane-among others. ${ }^{124}$ Yale had been an early holdout, preferring a method of instruction that involved lectures and recitations. ${ }^{125}$ By 1913, however, the Langdell method dominated the classes in all three years at Yale; in 1916 a Harvard Law School graduate-Thomas Swan-was appointed as Yale's dean. ${ }^{126}$ While much of this expansion was due to the direct transmission of the method by Harvard professors and graduates, who were its adherents, this "Harvardization" of American law schools was also motivated by the desire of prestige: "[O]nce elite law schools had decided to approve of the system, those aspiring to be considered elite rapidly followed." 127 No doubt the financial benefits of the method were an attraction as well; because it could be used with classes of large size, larger tuition-paying student bodies could be supported with relatively few professors. ${ }^{128}$ Regardless of the

122. See Proceedings of the Seventh Annual Meeting of the Association of American Law Schools, 31 AM. B. AsS'N REP. 1010, 1025 (1907) (“[W]e believe that men who are trained, by examining the opinions of the greatest judges ... are in a better position to know what legal reasoning is and are more likely to possess the power of solving legal problems . . ..").

123. Robert Stevens, LAW School: Legal Education in AMERICA FROM THE 1850 S TO THE 1980 s, at 60 (1983). Stevens reports that other faculty members, including Theodore Dwight, opposed the case method and resigned beginning in 1891. Id. This defection gave birth to The New York Law School. Id. at 75 n.21.

124. See id. at 60-61, 64 ("[B]y 1907, that number [of schools that had accepted the case method] had risen to over thirty.").

125. See FREDERICK C. HICKS, YALE LAW SCHOOL, 1869-1894, at 28-35 (1937) ("The traditional scheme of instruction was adhered to. It consisted chiefly of recitations on required reading supplemented by lectures and moot court work.").

126. SteVEnS, supra note 123 , at 62.

127. Id. at 63.

128. See id. ("The vast success of Langdell's method enabled the establishment of the large-size class.... Any educational program or innovation that allowed one man to teach even more students was not unwelcome to university administrators. The 'Harvard method of instruction' meant that law schools could be self-supporting."). 
reasons, the Langdellian model of legal education ultimately took hold and spread through law schools across the nation. ${ }^{129}$

It is worth noting that the rise of the Langdellian law school coincided with-and was doubtless aided by-the rise of the organized bar. Up through 1870, law practice varied greatly across the country but was largely characterized by practitioners who were not formally organized as a group with clear standards for preparation and admission. ${ }^{130}$ Local bar groups began organizing in cities such as New York and Chicago during the 1870s; in 1878, the American Bar Association (ABA) was founded for a mixture of reasons, including improving legal education and standards for admission to the bar. ${ }^{131}$ As the twentieth century arrived and progressed, the rise of corporations, administrative law, and business and banking regulation certainly made the practice of law more complex, changes that challenged the traditional, informal approach of reading for the bar. ${ }^{132}$ It is in this context that formalized legal education and the ABA's push for the same must, at least in part, be understood.

129. The model of university-based legal education did not catch on, however, in England. The University of London repeatedly tried to wrest the legal education of barristers from the Inns of Court during the late nineteenth and early twentieth centuries, to no avail. See Burrage, supra note 48, at 145 (noting that between 1884 and 1904 the University of London "made four separate proposals to establish a school of law jointly with the Inns" but that "the Inns remained unconvinced and rejected all proposals"). This resistance of the practicing bar to formalized, university-based legal education held up until the mid-twentieth century. Id. at 145-46. There was more success in moving the education of English solicitors into the University in the first half of the twentieth century, but that ended with a severance between the universities and the solicitor's professional association, the Law Society, in 1952, when all solicitors-in-training were withdrawn from the universities. See id. at 147 ("The universities paid little heed to the [Law Society's] criticisms, and in 1952 the Law Society therefore carried out its oft-repeated threat and withdrew all of its students from the universities.").

130. See James Willard HuRst, The Growth of AMERICAN LaW: THE LaW MAKERS 285-86 (1950) (discussing the formative history of bar associations in America).

131. Id. at $286-87$.

132. See id. at 308 ("Before [the 1870s] lawyers could educate one another to a large extent .... Before then the intricate web of administrative regulation had not been woven. After the '70s, the printed sources of the law became a flood ... and the reach of government vastly expanded."). 


\section{Over a Century of Critique and Reform}

"Our law schools, as usually conducted, offer nothing. Most of them do not, in their plan of study, seem ever to recognize the need."

$$
\text { -ABA Committee on Legal Education, } 1890133
$$

Although the Langdellian model of legal education became dominant and widely accepted in the early part of the twentieth century, it was not without its contemporary critics. Indeed, since the advent of the Langdellian law school, there has been a steady stream of critiques of legal education, each of which have had varying degrees of success in encouraging legal education reform. Sadly, however, when one canvases the various assessments of formal legal education over the past 130 years, it is remarkable how consistent the criticisms are and how persistent the Langdellian model has been in the face of these critiques.

\section{A. Early ABA Reports}

An early appraisal of the American law schools, at the time of Langdell, came from the ABA's Committee on Legal Education and Admission to the Bar in 1879:

But it is difficult to deny that there are American [law schools] not deserving of commendation. Institutions where the course is unjustifiably limited and circumscribed; where the term of study is evidently too brief for useful purposes; where students continue to be invited, when they are unfit by reason of deficient education and want of contact with liberal studies, to wrestle with the difficulties of the law; where, in a way unworthy of the cause of legal learning, a spirit of competition to attract greater numbers than are to be found in other establishments, is allowed to obtain control; where examinations, which are such only in name, take the place of a searching scrutiny of the student's acquirements; where there is no connection with any influence, except that of a faculty insufficient to meet the demands of a progressive time; where

133. William G. Hammond et al., Report on the Committee of Legal Education, 13 AM. B. Ass'N REP. 330 (1890) [hereinafter Hammond et. al., 13 AM. BAR ASS'N REP.]. 
there are no exercises sufficiently serious to try and develop the abilities the student may have; and where degrees are thrown away on the undeserving and the ignorant. ${ }^{134}$

Although this critique was contemporaneous with Langdell's reforms at Harvard, they cannot truly be said to reflect on Langdell's Harvard because at that point in time, Langdell's model had yet to spread to other law schools. ${ }^{335}$ Thus, the law schools being critiqued were largely those of the kind that preceded Langdell, including the kind that Harvard had been prior to the implementation of his reforms. Indeed, one can view Langdell's reforms as responsive in substance to many of the charges of the 1879 report: Langdell lengthened the period of study from eighteen months to three years, he implemented an undergraduate education requirement for admitted law students, he strengthened the examinations used to determine students' qualifications to advance and obtain the degree, and he sought to strengthen the faculty by moving towards full-time academics rather than practitioners who had less time to dedicate to the job of teaching law students. ${ }^{136}$

In the eyes of the ABA Committee on Legal Education, however, little had changed in law schools generally by 1890 , when it identified the defects of law schools as including the "constant temptation to attract more students and to graduate a large class by allowing all to get through who can 'cram up' for a not very rigid examination, which tests nothing but a mere recollection of the written letter of the law." 137 The Committee went on to observe that "all [law schools] suffer from the want of a proper standard of true legal education, a definite plan of the

134. Carleton Hunt, Report of the Committee on Legal Education and Admissions to the Bar, 2 AM. B. Ass'N REP. 219 (1879) [hereinafter Hunt, 2 AM. BAR Ass'N REP.]. It should also be noted that the Committee was critical of the failure of law schools to give instruction in Roman Civil Law, the law of nations, admiralty and maritime law, and comparative jurisprudence. Id. at 220-28.

135. See STEvens, supra note 123, at 60-64 (discussing the growth of Langdell's method of instruction in the late nineteenth century).

136. See supra Part II.E (providing an overview of Langdell's reforms to the legal education system of America).

137. Hammond et. al., 13 AM. BAR Ass'N REP., supra note 133, at 329. 
entire course."138 In its most damning critique, the ABA committee concluded its observations with the following analysis:

The defects of the present method may be summed up, we think, in one very familiar antithesis: they do not educate, they only instruct. They aim only to heap up in the student's mind a great mass of legal "points"-rules, definitions, etc.but they do not fashion these into a system, nor even do they give him the faculty of constructing for himself such a system. The mutual influences of different rules, the construction of legal relations and institutions, the processes by which the law is constantly developing and assuming new phases, are neglected, or, rather, positively ignored. He is supplied with an abundance of crude material, but not taught to use it. In office study, the daily participation in actual business gave the student at least some empiric training. He learned to use his acquisitions as an apprentice learns to use the tools of his trade.... The process was a rude and imperfect one, very uncertain in its results and exceedingly wasteful of time and labor, but for two or three centuries it has been the way in which English and American lawyers have been instituted, and it will not, perhaps cannot, be abandoned without something better is [sic] offered in its place. Our law schools, as usually conducted, offer nothing. Most of them do not, in their plan of study, seem ever to recognize the need. It is fortunate for them and for their pupils alike that the training thus omitted may be supplied in the early years of practice, at least to a very considerable extent. ${ }^{139}$

We see in this critique charges that could be leveled against law school education today. An instruction in legal "rules" dominates; a comprehensive legal education that synthesizes different areas of the law, teaches how to establish and maintain legal relationships or entities, and studies the processeslegislative, administrative, collaborative, and judicial-by which the law and legal relations are shaped is still "neglected" or "ignored" in law schools today. The charge that the student "is supplied with an abundance of crude material, but not taught to use it" is as true today as it was then at those schools that do not require extensive practical skills training or experience before graduation. Indeed, it can still be said of some law faculty that

138. Id. at 330 .

139. Id. 
they do not "seem ever to recognize the need" to offer training that approximates what students miss by not going through an apprenticeship experience. The key difference between now and then is that the saving grace for the Committee-"that the training thus omitted may be supplied in the early years of practice"-no longer accurately characterizes the opportunities facing most law school graduates today, given the increasing unwillingness of legal employers to foot the costs of basic training for new lawyers and the reality that many law graduates do not obtain work with employers who have the time, ability, or resources to support such training.

In the year following this report, 1891, the Committee again issued a report highly critical of the program of legal education at most law schools, this time focusing on the schools' emphasis on rules over principles and on rote memorization rather than reflection and analytical thinking:

The only method of teaching that deserves entire reprobation is that which encourages or even permits the student to make the entire course a mere exercise of memory, without reflection or judgment; not beginning with the fundamental notions or principles by which all his reasoning is to be conducted in actual practice, but laying up rule after rule, decision after decision, as if they were to constitute the fund of knowledge upon which he had only to draw during his after life.

Absurd as this method is to anyone who knows the daily work of an active practitioner, there is a fatal tendency toward it in much of the school routine.... No amount of text-book learning, no familiarity even with the cases will avail him, if he cannot reason from one set of facts to another by the use of the exact terms in which the law sums up its principles. ${ }^{140}$

This would appear to be a more direct attack on the Langdellian case method, ${ }^{141}$ though the larger point of the 1891 and 1890 critiques was the overemphasis of doctrine at the expense of

140. Hammond et. al., 14 AM. BAR ASS'N REP., supra note 34, at 332-33.

141. Such direct attacks continued in the 1892 report of the Committee, in which it faulted the case method for focusing on disputes rather than settled doctrines, training a student to be a "gladiator" more so than a counselor who can "advise a client when he is safe from litigation." William G. Hammond et al., Report of the Committee of Legal Education, 15 AM. B. Ass'N REP. 341 (1892). 
conveying fundamental and enduring legal principles, an understanding of the larger system formed by the law and the reason underlying it, and the ability to use such knowledge in practice.

Another common thread running through each of these critiques was the insufficiency of the modes of assessment, which simply required the memorization and regurgitation of rules. Not surprisingly, bar examination questions of the early twentieth century-not long after these ABA appraisals of law schoolswere similarly narrow in their approach to assessment, posing such questions as "How must a partnership exist?" and "Name the twelve maxims of Equity."142 Today, law schools remain focused on doctrinal instruction and summative assessments that test substantive knowledge and analytical abilities rather than the full range of skills needed by the active practitioner. Bar exams similarly remain oriented primarily towards doctrinal knowledge and analytical ability rather than practical competence. ${ }^{143}$

Through the remainder of the nineteenth century and into the early twentieth century, the Committee on Legal Education continued to monitor and recommend improvements to legal education. By 1912, the Committee's view of law school education had become more favorable, highlighting what it viewed as

142. Wormser, supra note 88 , at 34 (providing a critique of bar examination questions of the early twentieth century). Wormser, in his critique, questions:

What kind of nonsense, what order of foolishness is it, that impels us lawyers to agree that the vital necessity for the law-student is his acquisition of the power of logical analysis and thoughtful discrimination in handling legal propositions, and at the same time, leads us to furnish many a bar examination paper calculated to test little more than his memory...?

Id.; see also Gordon Hickey, After 100 Years, Bar Examiners Still Protecting the Public, 60 VA. LAW. 18, 18 (2012) (reporting questions from the first Virginia bar exam, including "What is a freehold estate?" and "What is the distinction between a vested and a contingent remainder?").

143. See, e.g., Va. Bd. of B. Examiners, Rules-Section I: Examinations (Aug. 2012), http://www.vbbe.state.va.us/pdf/VBBERules.pdf (noting that each examination consists of two parts, an essay part that tests the applicant's knowledge in twenty-two substantive law areas, and a multistate exam that tests knowledge in six substantive law areas). 
several advances in legal education that had occurred up to that time:

1. The recognition of the superiority of the law school over the office preparation for the Bar.

.

2. The recognition of a definite period of legal study upon the completion of which, and not before, the applicant can apply for admission to the Bar.

$\cdots$

3. The lengthening of the law school course of study to three years.

‥

4. The changed method of law instruction which has substituted in so many of the law schools of the country the study of law through cases, either as an exclusive system, or in combination with the use of text-books, in lieu of the old system of lectures, or of lectures and text-books.

. .

5. The development of a class of law teachers who are withdrawn from law practice, and whose vocation it is to teach law. ${ }^{144}$

Here we see the lauding of the case method of instruction as well as an approval of a full-time professoriate removed from the practice of law. ${ }^{145}$ Not wanting to rest on these laurels, however, the Committee, in 1913, asked the Carnegie Foundation for the Advancement of Teaching to undertake an investigation of legal education in the United States, one that would be similar to the Foundation's Flexner Report on medical education ${ }^{146}$ that devised

144. Henry Rogers et al., Report of the Committee on Legal Education and Admission to the Bar, 35 AM. B. Ass'N REP. 602-04 (1912).

145. It should be noted that this statement did not reflect an endorsement of a law professoriate wholly lacking in any practice experience. To the contrary, the Committee expressly indicated that "[i]t is desirable that law teachers, while withdrawn from practice, should have had actual experience at the Bar." Id. at 604.

146. See Abraham Flexner, Medical Education in the United States and CANAdA: A Report to THE CARnegie Foundation for the Advancement of TEACHING, Bulletin No. 4 (1910), available at http://www.carnegiefoundation. 
and recommended major changes to medical training that were adopted and characterize medical education today. ${ }^{147}$ The Carnegie Foundation obliged, and the products of that request were the 1914 Redlich Report and the 1921 Reed Report.

\section{B. The Redlich and Reed Reports on Legal Education}

For nearly a century, the Carnegie Foundation for the Advancement of Teaching has studied legal education and issued various reports and bulletins on the topic. The first of these, a report on the case method in American law schools, was published in 1914..$^{148}$ This topic was chosen because of the controversy surrounding the method; ${ }^{149}$ although legal instruction at Harvard Law School had come to be characterized by the casedialogue method under Langdell, the law professoriate and the practicing bar was not universally convinced of its efficacy. ${ }^{150}$ The Carnegie Foundation sought to shed light on this debate by enlisting a law professor from Austria-Josef Redlich-to visit American law schools and study the method from an impartial point of view. ${ }^{151}$

After spending two months visiting ten law schools-four of which did not employ the case method-Redlich generally concluded that the case method was meritorious, with a few caveats. ${ }^{152}$ Redlich quibbled with Langdell's claim that law was

org/sites/default/files/elibrary/Carnegie_Flexner_Report.pdf (providing the foundation's recommendations for changes to physician training).

147. See Molly Cook et al., Educating Physicians: A Call for Reform of MEDICAL SCHOOL AND RESIDENCY 1 (2010) ("Implementation of [Flexner's] blueprint has brought medical education to a high level of excellence.").

148. See REDLICH, supra note 95.

149. See id. at v ("At the outset of this study, one question quickly presented itself which involved fundamental ideas as to methods of instruction. Teachers of law in the United States ... divided into two rather distinct groups in their attitude toward what has come to be known as the Case Method.").

150. See id. at v-vi (describing two distinct groups holding differing opinions on case method instruction); see also 2 WARREN, HISTORY OF THE HARVARD LAW ScHOOL, supra note 54, at 496-518 (providing numerous contemporary commentaries of case method instruction).

151. See REDLICH, supra note 95, at vi.

152. See id. at viii (describing the virtues and drawbacks of the case method 
an inductive science for which the study of cases, as original sources, was well suited by pointing out that scientific inquiry is certainly not limited to inductive $\operatorname{methods}^{153}$ and that legal reasoning in any given case is actually deductive rather than inductive:

The judge who, in the individual case, decides according to the common law, applies ... to the state of facts then before him, one of these already existing norms... and pronounces... only the rule or norm applicable to the specific case. His intellectual activity in this is, therefore, essentially deductive; for by deduction we mean the application of an already existing general rule to the particular case. ${ }^{154}$

Redlich also distinguished legal science from the physical sciences by noting that the law does not consist of naturally observable facts, but rather of the products of human will directed at ordering and guiding human behavior, making law more of an "intellectual science" or "normative science."155 That said, Redlich did find that the case method was valuable in that it exposed students to mastery both of the content of the law and of the analytical methods lawyers must employ to make use of the law as practicing attorneys. ${ }^{156}$

system used in American law schools).

153. See id. at 55 ("Prominent though experimental and inductive methods are in the sciences which serve physical research, we press a generalization much too far when we make of the inductive method the sole criterion of scientific intellectual activity.").

154. Id. at 56-57.

155. See id. at 56

The science of law does not work, then, with physical facts, but with the products of the human will, which has been directed to the ordering and guidance of the individual and social life of humanity.... [L]egal science cannot deal with law in the sense of the physical investigator, but only with law in the sense of definite norms, willed by men, and intended to guide and limit the business of men.

156. See id. at 59

[O]n the ground that it is that method of instruction which is entirely suited to the established character of the common law, to independent intellectual assimilation of positive law from its sources, and to the highest development of the ability to think logically and systematically - on these grounds the case method must indeed be recognized as the scientific method of investigation and instruction in 
Redlich's general endorsement of the method was coupled with a caveat and a critique. The caveat was that the case method was appropriate for the study of Anglo-American law because such law-at that time-was largely unwritten, common law. ${ }^{157}$ With common law being case law, studying cases made sense, compared with the task of judges in civil law countries of finding the applicable rules and statutes that govern the facts at hand. ${ }^{158}$ Although the common law may have been prevalent during Langdell's time in the late nineteenth century, in the twenty-first century other sources of law-constitutional, statutory, regulatory, and negotiated-dominate the legal landscape, making it relevant to wonder whether the common law-based case method legitimately retains its purchase. ${ }^{159}$ Redlich's critique of the method was as follows:

It is characteristic of the case method that where it has thoroughly established itself, legal education has assumed the form of instruction almost exclusively through analysis of separate cases. The result of this is that the students never obtain a general picture of the law as a whole ....160

His prescription for remedying this defect was to create an introductory law school course:

[I]n American university law schools the students ought to be given an introductory lecture course, which should present, so to speak, 'Institutes' of the common law. Every department into which the American law is divided, whether as common

the common law.

157. See id. at 35 ("[T] method] is to be found in the present condition of American law, and within this especially in the unshaken authority of the common law.").

158. See id. at 36-37

To the Englishman and the American ... the law appears rather as the single case of law... conducted by the regular judge, and depending only upon his 'finding of the law.' The task of the European judge is to find which of the rules and principles of law that are contained in the system of law governs the state of facts in question.

159. See Rubin, supra note 101, at 619 ("To the extent that a national law school wants to teach the consensus view among state jurisdictions, it should be teaching the typical or model provisions of state statutes and regulations, not the common law.").

160. REDLICH, supra note 95 , at 41. 
law or equity, employs certain common elementary ideas and fundamental legal concepts, which the student ought to be made to understand before he is introduced into the difficult analysis of cases. ${ }^{161}$

This is sound advice even today, given the fact that pre-legal education does not offer such an overview. ${ }^{162}$ Pre-legal education is not formally connected with law school training in any way, ${ }^{163}$ meaning that students learn little about the legal profession and law school before deciding to become a lawyer, ${ }^{164}$ and are not guaranteed to have had any training or learning preparatory for the study of law. ${ }^{165}$ Indeed, American law schools typically offer a

161. Id. at 42 .

162. See HARNo, supra note 23, at 127 ("Many of the problems of legal education owe their being to deficiencies in the pre-legal period.").

163. See Preparing for Law School, AM. B. Ass'N, http://www.american bar.org/groups/legal_education/resources/pre_law.html (last visited Nov. 14, 2012) ("The ABA does not recommend any undergraduate majors or group of courses to prepare for a legal education. Students are admitted to law school from almost every academic discipline.") (on file with Washington and Lee Law Review).

164. See MACCRATE REPORT, supra note 22, at 228 ("Prospective law students generally are not knowledgeable about the profession . ...").

165. See Arthur T. Vanderbilt, A Report on Prelegal Education, 25 N.Y.U. L. REV. 199, 209-10 (1950)

It is no secret that our law school authorities generally are far from satisfied with the intellectual attainments of their incoming students .... To be specific, no instructor in any class in any law school can make a reference to Plato or Aristotle, to the Bible or Shakespeare, to the Federalist or even the Constitution itself with any real assurance that he will be understood.... Now even an allusion by a law school instructor to Adam Smith or Karl Marx is as likely as not to be lost, notwithstanding the preoccupation of our age with problems of economics.... [There is a] well-nigh universal criticism respecting the inability of law students to think straight and to write and speak in clear, forceful, attractive English. Almost everyone who discusses law school students-or even, it must be added, young law school graduates - has an unkind word to say about their lack of adequate powers of oral and written expression in their native tongue. Such criticism, on analysis, generally relates as much to defects in thinking as to faults of expression.

The 1980 report of the Special Committee on the Study of Legal Education of the ABA recommended that undergraduates should be urged to master advanced writing skills and effective oral communication, adding that prelaw courses should provide "a basic understanding of accounting, economics, psychology, and of historical and contemporary social and political processes." 
course of the kind proposed by Redlich to their foreign LL.M. students only, ${ }^{166}$ presumably under the assumption that American law students pursuing a J.D. would not benefit from this type of overview.

The Carnegie Foundation followed up the Redlich Report with a more comprehensive report on legal education authored by Alfred Zantzinger Reed and published in 1921. ${ }^{167}$ Right from the outset, the tenor of the Reed Report was less laudatory of law schools, as it began by bluntly proclaiming, "Our contemporary American system of legal education . . . is generally recognized to be defective in many respects." 168 As Reed traced the movement of legal education from the office to the school, he lamented the concomitant loss of practical training:

[W]e are in a fair way of losing entirely the practical training secured under a practitioner, that was once assumed to be the only logical means of preparing students in Anglo-American law. Even its remnants are not usually regarded by the law schools as worth preserving, now that they have virtually preempted the entire field of legal education. Moot courts... and "practice courses" are among the devices by which they

Am. B. Ass'n Special Comm. for a Study of Legal Educ., Law Schoois and PROFESSIONAL EDUCATION: REPORT AND RECOMMENDATIONS OF THE SPECIAL CommitTee for a Study of Legal Education of the AmERICAN Bar Association 104 (1980).

166. See, e.g., Course Descriptions, PENN STATE L., http://law.psu.edu/ academics/jd/course_descriptions (last visited Sep. 14, 2012) (describing the LL.M. course, Introduction to the U.S. Legal System, as "introduc[ing] the United States court system, the role of the Constitution ... and other foundation[al] materials in United States law. The goal is to introduce students to distinctive aspects and/or fundamental principles in U.S. law") (on file with the Washington and Lee Law Review); Introduction to the U.S. Legal System, FORDHAM UNIV. ScH. OF L., http://law.fordham.edu/llm-program/27293.htm (last visited Sept. 14, 2012) ("Welcome to the Introduction to the U.S. Legal System. As you know, this course is required for all students who do not hold a degree from a U.S. law school.") (on file with the Washington and Lee Law Review). For Redlich's recommendations, see supra notes 160-61 and accompanying text.

167. REed RePORT, supra note 1. See also STEVENS, supra note 123, at 11213 (describing the Carnegie Foundation funding both the Reed and Redlich reports). Reed published a further report on legal education funded by the Carnegie Foundation in 1928. See AlFred Zantzinger REed, PRESEnT-Day LAW Schools in the United STATES AND CANAdA, Bulletin No. 21 (1928) [hereinafter REED REPORT II].

168. REED REPORT, supra note 1 , at 3. 
conceal from themselves and others the necessarily theoretical character of their instruction. ${ }^{169}$

This neglect of the practical was, for Reed, unconscionable: "The failure of modern American law school to make any adequate provision in its curriculum for practical training constitutes a remarkable educational anomaly."170

Reed's concern over the absence of practical training came in the context of a declining presence of law office apprenticeship training as supplementary to formal academic legal training. As early as the late nineteenth century, the ABA was urging that law school be accepted as a substitute for law office training rather than its mere predicate. ${ }^{171}$ By 1895 , law school study and clerkship training had come to be regarded as interchangeable, rather than indispensable, in legal education, though no state bar admissions authorities were requiring law school at that time. ${ }^{172}$ And by Reed's time, four states were requiring formal legal education at law school, and in almost all of the remaining jurisdictions, "law school and law office training had become alternatives."173 In a context in which apprenticeship training had become optional, it is little wonder that Reed found fault with law school's failure to attend to practical instruction.

Another major strain of Reed's critique was of what he referred to as "the theory of a unitary bar, whose attainments are to be tested by uniform examinations."174 This theory held that rather than having different kinds of lawyers, who were differently qualified to handle different matters, our political

169. Id. at 48 .

170. Id. at 281 .

171. See Transactions of the Forty-Second Annual Meeting of the American Bar Association, 42 AM. BAR AsS'N REP. 28-30 (1919) (adopting a resolution that "time spent in any chartered and properly conducted law school ought to be counted in any state as equivalent to the same time in an attorney's office in such state ....").

172. See STEVENS, supra note 123, at 95 ("[T]ime spent in law school came to be counted as time spent in a law office, as states gradually increased (or restored) the requirement for some kind of apprenticeship or clerkship. Yet no state required attendance at law school ....").

173. See id. at 174 (noting that by 1930 only West Virginia, Colorado, Kentucky, and Wyoming required at least one or more years of legal education).

174. REED REPORT, supra note 1, at 57. 
philosophy abjured distinctions and ranks among lawyers, resulting in the "American 'attorney and counselor-at-law,' privileged to practice all branches of his profession in all courts equally."175 The unitary bar theory, in Reed's view, obscured the real distinctions between the law schools, mainly the divide between the full-time national law schools and the local law or part-time law schools, which "differ[ed] vastly from one another in type of law studied, in methods of instruction, and in the amount of actual work represented by their degree."176 The problem here was that the unitary ideal forced each type of law school to compete with the other, to the detriment of each: "Coming, however, into direct competition with one another under the accepted dogma of a unitary bar, each affects injuriously the other's development." 177 Further, the notion of a unitary bar was at odds with the needs of the increasingly pluralistic society that was 1920 s America. ${ }^{178}$

In Reed's estimation, the three types of emerging law schools-full-time national, full-time local, and part-time evening-represented different approaches to legal education that should be encouraged and strengthened rather than homogenized or suppressed:

Each has seen clearly that if all American lawyers were educated in accordance with the other's plans, we should be in a bad way .... If [some] thought ... had been expended upon

175. See id. at 39-40 (describing the transformation of the legal profession as moving "as a whole into an officially undifferentiated and, as it were, flattened-out profession").

176. Id. at 63 .

177. Id. at 64. Reed posited that "the night schools are damaged by the obligation placed upon them to cover the same curriculum as the day schools." Id. at 57. The full-time schools "are so fearful of losing students to [the night schools], that they hesitate to raise their own entrance requirements to the level that they really believe in." $I d$. at 58. Bar examiners, eager not to favor graduates of one type of school over the other, "are obliged to limit the scope of their enquiries to those elements that any law school, offering the standardized curriculum, must provide-something that even the more poorly trained of the night school students can pass, at least with the aid of special coaching . ..." Id. at 59 .

178. See STEVENS, supra note 123, at 113 (describing Reed's view of a pluralistic 1920s America as "st[anding] out sharply against the formal theory of a unified bar"). 
the problem of dividing the bar along lines that can be justified ... we should hardly have been in so bad a situation as we are now, when the schools are... wrangling for possession of a field too large for any of them to cover in its entirety. The scholarly law school dean properly seeks to build up a "nursery for judges" that will make American law what American law ought to be. The practitioner bar examiner, with his satellite schools, properly seeks to prepare students for the immediate practice of the law as it is. The night school authorities, finally, see most clearly that the interests not only of the individual but of the community demand that participation in the making and administration of the law shall be kept accessible to Lincoln's plain people. All these are worthy ideals. Taken together, they roughly embrace the service that the public expects from its law schools as a whole. But no single institution, pursuing its special aim, can attain both the others as well. ${ }^{179}$

By permitting this differentiation to thrive, Reed estimated that schools would be able to focus on what they each did best, producing graduates who were well-suited for the kind of lawyering that was the focus of their respective schools. ${ }^{180}$

The ABA Section of Legal Education and Admissions to the Bar, which in 1919 superseded the abolished Committee on Legal Education and Admissions to the Bar, ${ }^{181}$ received an early draft of the Reed Report in 1920 and did not like what it saw. ${ }^{182}$ It promptly formed a special committee chaired by Elihu Root, which met in March and May of 1921 and was tasked with developing its own recommendations for improving legal education. ${ }^{183}$ Regarding Reed's suggestion that the diversity in

179. REED REPORT, supra note 1 , at $417-18$.

180. See id. at 417-19 ("[T] he independent development of each type of law school will naturally result in a considerable variation in the kind of professional work for which its products are especially fitted.”).

181. Constitution and By-Laws of the American Bar Association, 42 AM. B. ASS'N REP. 121-31 (1919).

182. See STEVENS, supra note 123, at 115-16 ("Reed's suggestion in his first report that the most democratic, egalitarian, and American solution would be a differentiated bar, with differing types of law schools ... managed to offend both his ABA and AALS audiences.").

183. See Report of the Special Committee to the Section of Legal Education and Admissions to the Bar of the American Bar Association, 44 AM. B. Ass'N REP. 679-88 (1921) [hereinafter Special Committee Report, 44 AM. BAR Ass'N REP.] 
types of law schools should be encouraged, the Root Report stated as follows:

Turning first, then, to a consideration of what a lawyer's training should be, we meet the suggestion that there must be different kinds of training to produce different kinds of lawyers.

With this position we do not agree. In spite of the diversity of human relations with respect to which the work of lawyers is done, the intellectual requisites are in all cases substantially the same. ${ }^{184}$

The Root committee's view was that differentiating among law schools meant tolerating law schools of lesser quality: "Nor can there be tolerated a recognized distinction between good and poor legal education. There should be no distinction .... [W] cannot favor the continuation of a class of incompetent practitioners." 185 Uniformity was to be preferred, which the special committee went about pursuing by recommending that all bar applicants be required to have graduated from a law school complying with prescribed standards, that they be required to have completed at least two years of study in college, and that the course of full-time study of law be three years. ${ }^{186}$

The Root committee acknowledged the need for afternoon and evening law schools to accommodate the student who had to work to support himself and his family; however, it rejected the idea that such schools should be operated with what it viewed as lower educational standards. ${ }^{187}$ Finally, the Root committee

(describing the proceedings of the special committee chaired by Elihu Reed in March and May of 1921 to the full Section on Legal Education and Admissions to the Bar).

184. Id. at 681 .

185. Id. at 681-82.

186. See id. at 683-85 (spelling out the special committee's recommendations for uniformity).

187. Id. at 685. Specifically, the special committee noted:

But in recognizing the necessity for afternoon and evening schools we do not recognize the propriety of permitting such schools to operate with low educational standards .... On the contrary, the democratic necessity for afternoon and evening schools compels a lifting of these schools to the highest standards which they can be expected to reach.

Id. 
recommended that "a law school shall not be deemed competent to educate students for the bar unless it provides an adequate library available for their use" and that a school "have among its teachers a sufficient number giving their entire time to the school." 188 These requirements, of course, would prove to be more burdensome to night schools and local, practice-connected schools that might lack sufficient funds to maintain a complete law library and whose instructors were principally practitioners who devoted most of their time to law practice during the day. These requirements all meant to homogenize law schools around standards that tilted in favor of the national, full-time law schools, to the detriment of night schools and other alternative types of law schools that might have otherwise been able to develop, the latter being schools that non-elites and working class individuals were more likely to be able to attend. ${ }^{189}$

One can hardly quarrel with the notion that there should not be law schools that expressly aspire to lower educational standards or knowingly produce a class of incompetent practitioners. But that is a straw man and as such was not the proposition furthered by Reed in his report. ${ }^{190}$ Rather, the idea was that the variation among types of law schools should be recognized in a way that permits each to focus on their respective strengths in service of various segments of the public and bar. ${ }^{191}$ Reed did not know what such a regime would look like in its

188. Id. at $685-86$.

189. The Association of American Law Schools (AALS), whose membership consisted of the elite law schools, similarly opposed the idea of a differentiated bar or the perpetuation of a separate, lower class of law schools. See STEVENS, supra note 123, at 116 (describing the membership of the AALS and referring to the 1921 presidential address by Yale's Arthur Corbin to the AALS that "reject[ed] any concept of a differentiated bar").

190. See REED REPORT, supra note 1, at 55-56 (describing the development of different institutions to serve those who can devote all their time to legal education while addressing "the democratic desire to extend the privileges of education to the many").

191. See id. at 56-57 ("If law school graduates enjoyed different privileges in the practice of law, corresponding to the differences in educational effort between full-time and part-time work, the two types instead of rivaling would supplement one another. Each could develop independently along the lines indicated by its own special aim."). 
particulars, ${ }^{192}$ but it is likely that he would endorse moves from some quarters today to get the $\mathrm{ABA}$ to amend its approval standards to allow creative flexibility among the law schools; that is, efforts such as those that relax the tenure requirement in favor of alternative means of giving faculty security of position ${ }^{193}$ might permit some schools, for example, to build a faculty of practitioners who practice during the day and teach only at night. ${ }^{194}$ Relaxing other standards such as the full-time faculty and library requirements or the limitations on distance

\section{See id. at 419}

The more scholarly institutions may in time be glad to lighten their own burden by throwing upon schools of other types responsibility for certain portions of this broad field. Conveyancing, probate practice, criminal law and trial work are examples of topics that seem particularly appropriate for the relatively superficial schools. All this is mere guesswork, however. It is not even certain that a rigorous functional division of the bar will ever develop. The dividing line between the different types of lawyers may be determined by the economic status of the client rather than by the nature of the professional service rendered. The general principle of a differentiated profession is something that we already have, and could not abolish if we would. The particular principle of a functionally divided bar is something that we may or may not be able eventually to introduce, as one means for making the general principle work better.

193. See ABA Standards and Interpretations on Faculty, Standard 405 (Discussion Draft 2011), available at http://www.americanbar.org/content/dam/ aba/migrated/2011_build/legal_education/committees/standards_review_docume nts/july2011meeting/20110711_ch_4_faculty_terms_and_conditions_july_10_201 1_discussion_draft.authcheckdam.pdf (presenting two alternative proposals that relax or eliminate the requirement of faculty tenure); see also Mark Hansen, ABA Committee Considers Changes in Terms and Conditions of Law School Employment Policies, A.B.A. J. (Jul. 11, 2011, 7:34 PM), http://www.aba journal.com/news/article/aba_committee_considers_changes_in_terms_and_cond itions_of_law_school/?utm_source $=$ feedburner\&utm_medium $=$ feed\&utm_campai gn $=\mathrm{AB} \overline{\mathrm{A}}+\mathrm{J}$ ournal+Daily+News\&utm_content $=$ Netvibes (last visited Aug. 31, 2012) (discussing ABA Standards Review Committee proposals to permit law schools that do not offer tenure to demonstrate alternative sufficient means of providing security of position) (on file with the Washington and Lee Law Review).

194. See, e.g., BIRMINGHAM Sch. OF L., http://www.bsol.com/ (last visited Aug. 24,2012 ) (describing a non-ABA-accredited school taught by practicing lawyers and judges whose graduates may sit for the Alabama bar exam) (on file with the Washington and Lee Law Review). 
education ${ }^{195}$ _might similarly free law schools to deliver an education sufficient to serve a different segment of the bar than might a graduate of a national full-time law school.

The challenge would be on the licensing side; state licensing authorities would be responsible for determining whether graduates of all law schools were prepared to practice, something most bar exams, as structured at the time, largely failed to do. ${ }^{196}$ Beyond making bar exams a better judge of practice-readiness and legal competence, ${ }^{197}$ one could imagine a differentiated bar with various levels of licensure. Such a system would not have to mimic the barrister-solicitor distinction of England precisely, ${ }^{198}$ but that model at least could be an example of where to start the thought process. Alternatively, phased licensure could be

195. Current ABA Standards limit the credit that students may receive through distance education to four hours in any term and twelve hours overall. 2012-2013, ABA STANDARds AND Rules of Procedure For Approval of LAw Schools, supra note 28, Standard 306(d). The Standards Review Committee considered revising this standard, but only to permit fifteen hours total of distance education to count towards the J.D. degree. See AM. B. Ass'N SECTION of Legal Education AND Admissions to the BAR, Standard 311(f), (Proposed Draft 2011) [hereinafter 2011 Proposed Draft], available at http://www. americanbar.org/content/dam/aba/migrated/2011_build/legal_education/committ ees/standards_review_documents/jan2012/20111222_standards_chapters_1_to_7 _post_nov11.authcheckdam.pdf. Currently, there is one completely online law school, The Concord School of Law, which is ineligible for ABA approval due to Standard 306. However, one of its graduates did successfully petition the Massachusetts Supreme Judicial Court for permission to sit for that state's bar exam, which he passed. See Kristina Horton Flaherty, Court Win for Online Law School Grad, CAL. B. J. (Jan. 2009), http://archive.calbar.ca.gov/Archive.aspx?

articleId=94802\&categoryId=94651\&month=1\&year=2009 (last visited Aug. 31, 2012) (on file with the Washington and Lee Law Review).

196. See REED REPORT, supra note 1, at 59 ("The actual situation is that neither the tests of the state nor those of the law schools serve to prevent incompetents from flooding the profession.").

197. See, e.g., ALI-ABA Continuing Prof. Educ. \& Ass'n of Continuing

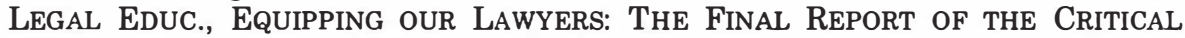
ISSUES SUMMIT 8 (2010), available at http://www.equippingourlawyers. org/documents/final_report.pdf ("Regulatory authorities should consider restructuring one-time bar examinations into phased examinations over time, linked in part to attainment of legal practice skills, with some parts of the examination occurring as early as in the law school years.").

198. See Mary Ann Glendon, Michael Wallace Gordon \& Christopher Osakwe, Comparative Legal TRaditions 546-49 (2d ed., 1994) (describing the distinction between English barristers and solicitors). 
considered, with probationary or apprenticeship periods preceding full admission, as is currently the approach in Canada. ${ }^{199}$ Whatever the specifics might be, revising the ABA standards in a way that permits flexibility while ensuring that basic levels of quality are maintained-in tandem with improved state bar admissions standards-seems to be the ideal that Reed was endorsing and would seem to be a way to free law schools to pursue their respective strengths without having to devote resources toward compliance with standards that do not truly speak to their core mission and the segment of the bar they serve.

But this was not to be; the Section rebuffed the Reed Report's recommendation to permit the development of fundamentally different types of law schools in favor of a unitary set of standards that required all law schools to aspire toward and satisfy its vision of what was required to make a law school educationally sound. ${ }^{200}$ There was notable opposition to the

199. See Articling Program: What You Need to Know, L. Soc'Y Of UPPER CAN. (May 2012), http://www.lsuc.on.ca/ArticlingNeedtoKnowInfo/ (last visited Aug. 24, 2012) (describing the ten-month articling program in the Canadian licensing process) (on file with the Washington and Lee Law Review).

200. See Special Committee Report, 44 AM. BAR ASs'N REP., supra note 183, at 683 . The committee noted that:

To require a law-school education without setting standards for the law schools would be worse than useless. Any man or group of men professing to teach law to students may be said to be conducting a law school, no matter how inferior may be the abilities of the students, the nature of the instruction or the physical facilities of the plant .... We, therefore, propose not only that a law school education shall be required, but that such education must be obtained in a school complying with certain prescribed standards.

Id.; see also Proceedings of the Section of Legal Education and Admissions to the Bar, 46 AM. B. Ass'N REP. 678 (1923). The Council came to the following conclusion:

[T] hat a school, to be in the approved list, must comply as to all of its students. Some schools or some institutions conduct classes both for full time and part time students. Some of these have arranged to comply with the standards of the American Bar Association or announced that they will in the near future comply with such standards as to their full time students, but have not arranged to so comply as to their part time students. The Council has concluded that such schools cannot be placed on the approved list.

Id. 
standards proposed by the Section; Dean Edward T. Lee of the John Marshall Law School of Chicago argued:

The effect of the adoption of the recommendations would be to place the control of legal education through the country in the hands of the deans of a few large day law schools who have the fate of law teachers in their hands. It would close the profession of the law to all save the leisure class of youth with means sufficient to obtain college and law school training ....201

Nonetheless, the ABA approved the Section's recommendations at its 1921 meeting ${ }^{202}$ and they were subsequently approved by the Conference of Bar Association Delegates held in Washington, D.C. in $1922 .{ }^{203}$

\section{Twentieth Century Critiques and Reforms}

"[I]s it not plain that, without giving up entirely the case-book system or the growing and valuable alliance with the so-called social sciences, the law schools should once more get in intimate contact with what clients need and with what courts and lawyers actually do?"

-Jerome Frank, $1933^{204}$

The ABA's determination to impose its unitary vision of law schools based on the Langdell model-three years of full-time study (or its equivalent if part-time), centered around large physical libraries, and classes taught by full-time faculty members removed from the practice of law-was a victory for the full-time national law schools that furthered the Harvardization of legal education. ${ }^{205}$ It was not long, however, before another

201. Proceedings of the Section of Legal Education and Admissions to the Bar, 44 AM. B. Ass'N REP. 668 (1921) (discussing the report of the Special Committee).

202. See Transactions of the Forty-Fourth Annual Meeting of the American Bar Association, 44 AM. B. Ass'N REP. 37-47 (1921).

203. See Proceedings of the Special Conference on Legal Education, 45 AM. B. ASS'N REP. 482-84, 582 (1922).

204. Jerome Frank, Why Not a Clinical Lawyer-School?, 81 U. PA. L. REV. 907, 913 (1933-1934) [hereinafter Frank, Why Not a Clinical Lawyer-School?].

205. See REED REPORT, supra note 1, at 410 ("The path indicated by 
major threat to the Langdellian model for the study of law in the first half of the twentieth century reared its head. This challenge came from what came to be referred to as the legal Realists, who challenged "the Langdellian notion of law as an exact science, based on the objectivity of black-letter rules."206 Instead, the Realists posited that the operation of the law in the real world was less coherent and objective than Langdell's scientific vision of the law suggested. ${ }^{207}$ With law as a value-laden process more so than a neutral and consistent body of enduring principles, Langdell's belief in cases as the vehicle for learning legal doctrine and in the mastery of doctrine and principles as the route to becoming a good lawyer became subject to doubt. ${ }^{208}$

In 1933, Jerome Frank reflected the Realists' view in his withering critique of the Langdellian case method:

Ostensibly, the students were to study cases. But they did not and they do not study cases. They do not even study the printed records of cases (although that would be little enough), let alone cases as living processes. Their attention is restricted to judicial opinions. But an opinion is not a decision. A decision is a specific judgment, or order or decree entered after a trial of a specific lawsuit between specific litigants. There are a multitude of factors which [sic] induce a jury to return a verdict, or a judge to enter a decree. Of those numerous factors, but few are set forth in judicial opinions. And those factors, not expressed in the opinions, frequently are the most important in the real causal explanation of the decisions. ${ }^{209}$

Harvard ... has been followed by all the schools. Their main activities are devoted to instruction in the relatively narrow... field of the judge-made technical law."); see also id. at 411-12 (describing innovations in legal education emanating from Harvard that took hold, including the focus on "national" law, introduction of the case method, and imposition of the requirement of preliminary college training before entering law school). For a fuller account of the standardization movement by the ABA and the AALS, see STEVENS, supra note 123 , at $205-13$.

206. STEVENS, supra note 123 , at 156.

207. See id. ("The Realists went a long way toward killing the idea of "the system' altogether. All legal logic came under suspicion. American law became increasingly purposive, increasingly secularized, and increasingly atomized.").

208. See id. at 156-57 ("This change inevitably caused the predictive value of doctrine to be seriously questioned.").

209. Frank, Why Not a Clinical Lawyer-School?, supra note 204, at 910. 
From the Realist perspective, the law in books-particularly books limited to reports of appellate opinions-was not the sum total of what constituted the law nor even the best source for understanding law or legal practice. ${ }^{210}$ Frank argued for the study of complete case files-not simply appellate opinions-and for study of the work of lawyers in practice and the work of the courts:

[T] he study of cases... should be based to a very marked extent on reading and analysis of complete records of casesbeginning with the filing of the first papers, through the trial in the trial court and to and through the upper courts. Six months properly spent on one or two elaborate court records, including the briefs (and supplemented by reading of text-books as well as upper court opinions) will teach a student more than two years spent on going through twenty of the case-books now in use. ${ }^{211}$

Karl Llewellyn, during his time at Columbia Law School, raised similar points, suggesting the case approach used in business schools as a way of improving on the Langdellian case method. ${ }^{212}$

Another Realist critique was of the abstract focus and dearth of practical training that characterized law schools. Fred Rodell

210. See Jerome Frank, What Constitutes a Good Legal Education?, 19 A.B.A. J. 723, 726 (1933) [hereinafter Frank, What Constitutes a Good Legal Education?] (noting the advantages of studying case files over court opinions). Frank noted:

The law student should learn, while in school, the art of legal practice. And to that end, the law schools should boldly, not slyly and evasively, repudiate the false dogmas of Langdell.... They must decide not to exclude, as did Langdell, but to include the "methods of learning law by work in the lawyer's office and attendance upon the proceedings of courts of justice. ..." They must repudiate the absurd notions that the heart of a law school is its library ....

Id. (citations omitted)

211. Frank, Why Not a Clinical Lawyer-School?, supra note 204, at 916.

212. See Karl N. Llewellyn, The Current Crisis in Legal Education, $1 \mathrm{~J}$. LEGAL EDUC. 211, 215 (1948-1949) ("Consider, for example, the possibility of building up our so-called cases out beyond the judicial opinion into something resembling the completeness of the cases gathered for the Harvard Business School."). For an exposure to the Harvard Business School case method, see The Case Method at HBS, HARVARD Bus. SCH., http://www.hbs.edu/teaching/insidehbs/ (last visited Sept. 1, 2012) (on file with the Washington and Lee Law Review). 
of Yale found fault with the focus on abstractions rather than on practical legal problem-solving when he wrote, "[T]hus, law school courses, since they are cut out of the pseudo-science of Law, inevitably focus on generalities and abstractions rather than on the solution of specific problems." ${ }^{213}$ In 1928, Alfred Reed of the Carnegie Foundation commented on the need for more practical instruction in his second report on legal education in which he faulted the law schools for their failure to provide students with practical experience:

[A]ll the activities of the school are necessarily conducted under artificial conditions. The hurly-burly of actual practice is systemized for the student in a manner that it never is when an authentic client begins to tell him his woes. This systemization is indispensable as a means of ensuring him adequate resources of information and of developed reasoning power upon which to draw. But there still remains the task of marshaling these resources, of focusing his scattered acquisitions upon the unlabeled and multifarious collection of facts and aims with which he will be called upon to deal. Skilled ability to do this is what distinguishes the lawyer from the legal scholar, the expert practitioner from the man who knows, or who is qualified to ascertain, the law. ${ }^{214}$

Reed favored further experimentation with legal clinics associated with law schools as a way of ameliorating this condition. ${ }^{215}$ Jerome Frank suggested the same only a few years later. ${ }^{216}$

These points were well taken; however, they did not lead to a wholesale overhaul of legal education away from the Langdellian model. Instead, law schools responded by supplementing their curricula with practice courses in the form of legal clinics. ${ }^{217} \mathrm{By}$

213. Fred Rodell, WoE UNTO You, LAWYers! 207 (1939).

214. REED REPORT II, supra note 167 , at 215.

215. See id. at 216-21 ("If by this method lawyers who enter the legal profession through the law schools can acquire even a small amount of that practical experience which they now so sadly lack, the plan is certainly worth putting into operation.").

216. See Frank, Why Not a Clinical Lawyer-School?, supra note 204, at 917 ("Suppose, however, that there were in each law school a legal clinic or dispensary.").

217. See STEVENS, supra note 123, at 214-16 ("Of all aspects of the renewed interest in skills, the particular interest in the skills embraced in the concept of 
1951, there were twenty-eight clinics maintained by law schools, independent legal aid societies, or public defender offices. ${ }^{218}$ The movement grew stronger over the next two decades, resulting in clinical programs at nearly half of the law schools in the country by the early 1970 s. ${ }^{219}$

Although the rise of clinical legal education was a major innovation in how law schools prepared their students for practice, very little change in the law school program had occurred overall. ${ }^{220}$ Indeed, criticism of the legal profession persisted in the 1970s, a critique that extended to law schools as the near exclusive route to practice.221 As the second and third years of law school had become largely elective and focused on courses not necessarily oriented towards practice, bar admissions authorities began considering imposing practice course requirements as prerequisites to admission. ${ }^{222}$ In 1971 , the AALS issued the report of its Curriculum Study Project-known as the Carrington Report-which called for a curriculum that emphasized practice-oriented courses in the first year. ${ }^{223}$ A 1972

clinical legal education was to prove the most important."). Other reforms were implemented during the post-World War II period as well, including the introduction of elective courses, seminar courses, introductory law courses, writing programs, small group discussions, reduced class sizes, and the like. See id. at 211-14 ("[T]here had been a realization that there were important skills other than those inculcated by the case method .... Discussions of curricular reform increasingly centered on skills such as negotiation, drafting, and counseling-legal skills that had had no place in the Langdellian scheme of things.").

218. STEVENS, supra note 123, at 215.

219. Id. at 216.

220. See id. at 232 ("[B]y the mid-1960s ... [t] [here had been much talk of change, but little change had occurred."). Readers should consult Stevens's book on the history of legal education for a much more complete account of what transpired in legal education during this time period.

221. See id. at 232-38 ("Increasingly, the leaders of the bar expressed concern that the law schools were not living up to their expectations .... The bar was irritated by an apparent reluctance on the part of leading schools to be concerned with those skills that the profession regarded as important ....").

222. See id. at 238-39 (discussing the Second Circuit's proposal to require that applicants have taken evidence, civil procedure, criminal procedure, professional responsibility, and trial advocacy); see also id. at 239-40 (discussing efforts of other jurisdictions to impose law school course prerequisites to bar admission).

223. See Paul D. Carrington, Ass'n Am. L. Schs., Training for the Public 
report sponsored by the Carnegie Commission on Higher Education noted the encouraging expansion in clinical legal education but cautioned that proper supervision and instruction were required to make real life experiences edifying and educationally sound, and doubted whether clinical education ultimately could be "the solution" to the host of ills that plagued legal education given its costs. ${ }^{224}$

In 1979, the ABA entered the dialogue by publishing the report of its Task Force on Lawyer Competency entitled The Role of Law Schools, in which it observed, "Law schools, have not . . . undertaken to provide such comprehensive training that individuals emerge upon graduation as fully competent ready-topractice lawyers." 225 The Task Force then emphasized the need for improvement in the following areas:

(a) developing some of the fundamental skills underemphasized by traditional legal education; (b) shaping attitudes, values, and work habits critical to the individual's ability to translate knowledge and relevant skills into adequate professional performance; and (c) providing integrated learning experiences focused on particular fields of lawyer practice, including but not limited to trial practice. ${ }^{226}$

Toward that end, the Task Force recommended that law schools provide instruction in fundamental skills critical to lawyer competence: effective writing, oral communication skills, factgathering, interviewing, counseling, and negotiation skills. ${ }^{227}$ It went on to recommend teaching these fundamental lawyer skills in small classes, that schedules be adjusted to "provide [the] opportunity for periods of intensive instruction in fundamental

Professions of the Law: 1971, Part One, Section II (1971), reprinted in HERBERT L. PACKer \& Thomas Ehrlich, New Directions in Legal EduCATion: A Report PREPARED FOR THE CARNEgIE COMMISSION ON Higher EDUCATION 93, 110-17 (1972) [hereinafter CARRINGTON REPORT] (including, among others, a course entitled legal advocacy to be completed in the first year of law school where "[e]mphasis is placed on the need to develop and use professional skills").

224. See PACKER \& EHRLICH, supra note 223 , at $42-43,46$ ("We prefer to think that the path of improvement lies in experimentation with many modest ideas, one of which is clinical education.").

225. CRAMTON REPORT, supra note 22, at 11.

226. Id. at 14 .

227. Id. at 3 . 
lawyer skills," that law schools encourage more cooperative law student work, and that "law schools should make more extensive instructional use of experienced and able lawyers and judges." 228 Also noteworthy was its recommendation that law schools "develop and use more comprehensive methods of measuring law student performance than the typical end-of-the-term examination" and that "[s]tudents should be given detailed critiques of their performance." 229 Finally, with respect to the academic program, the Task Force urged law schools to "seek to achieve greater coherence in their curriculum," noting that "the three-year program should build in a structured way."230 Notwithstanding these recommendations, when a proposal to require that law schools offer practical skills instruction as a condition of accreditation was presented to the ABA by the Council of the Section on Legal Education, the ABA softened the proposal by limiting it to an interpretative paragraph calling for skills training rather than an approval standard mandating such training. ${ }^{231}$

More than a decade later, legal education still was perceived as inadequately preparing students for practice, as little had changed in how law schools educated their students. ${ }^{232}$ The ABA spoke to this concern in a 1992 report known as the MacCrate Report. ${ }^{233}$ The MacCrate Report outlined a series of skills and values that were deemed to be essential for competent representation, and then recommended that law schools offer courses that effectively instruct students in those areas. ${ }^{234}$ The fundamental lawyering skills outlined included problem solving,

228. Id. at 4.

229. Id.

230. Id.

231. SteVEnS, supra note 123 , at $240,257 \mathrm{nn} .88-89$.

232. CARNEGIE REPORT, supra note 22, at 93 ("[T] hese efforts failed to change the standard pattern of law school education.").

233. See MACCRATE REPORT, supra note 22.

234. See id. at 330-34 (identifying three characteristics of effective lawyering skills teaching including: the "development of concepts and theories underlying the skills and values being taught; opportunity for students to perform lawyering tasks with appropriate feedback and self-evaluation; [and] reflective evaluation of the students' performance by a qualified assessor"). 
legal analysis and reasoning, legal research, factual investigation, communication, counseling, negotiation, knowledge of litigation and $\mathrm{ADR}$ procedures, law-practice management, and the ability to recognize and resolve ethical dilemmas. ${ }^{235}$ The four values suggested by the report were the provision of competent representation, striving to promote justice, fairness, and morality, striving to improve the profession, and professional selfdevelopment. ${ }^{236}$ The report also explored the state of skills instruction offered in law schools at the time, finding that a majority of law graduates had only one or no professional skills courses beyond basic legal research and writing courses, trial advocacy, or moot court experiences. ${ }^{237}$ The report found that clinical programs were generally available to only thirty percent of law students at schools where such courses were offered, with skills training courses occupying only nine percent of the total instructional time at law schools. ${ }^{238}$

An important perspective offered by the MacCrate Report was the importance of the entire legal educational continuumpre-law, law school, bar admissions, and continuing legal education-and it addressed the need for improvements to occur at each stage. ${ }^{239}$ Ultimately, the report concluded that greater attention should be paid to "the linkage between the several phases of lawyers' education" if the gaps in professional legal education are to be filled. ${ }^{240}$ Although the report spawned some efforts to increase skills instruction in law schools, such training has remained peripheral to legal education ${ }^{241}$ and no grand effort

235. Id. at $138-40$.

236. Id. at $140-41$.

237. Id. at 240 .

238. Id. at 240-41.

239. See id. at 3-8 ("The skills and values of the competent lawyer are developed along a continuum that starts before law school, reaches its most formative and intensive stage during the law school experience, and continues throughout a lawyer's professional career.").

240. Id. at 320-21. The report proposed the creation of a national institute to attend to this coordination. Id.

241. See CARNEGIE REPORT, supra note 22, at 94 ("[S]kills training will continue to face an uphill battle unless it is linked with an accepted theory of lawyering that could provide a bridge between theory and practice and perhaps establish a rationale for more systemic continuing education beyond law 
to coordinate the various phases of legal education has materialized.

\section{Contemporary Critiques}

In 2007, a group of researchers compiled a report entitled Best Practices for Legal Education (Best Practices) that began by echoing the MacCrate Report's charge that multiple stages along the legal education continuum had substantial room for improvement. ${ }^{242}$ Specifically, the report noted that law graduates "are not sufficiently competent to provide legal services to clients or even to perform the work expected of them in large firms" and that survey after survey has reported a decline in lawyer professionalism. ${ }^{243}$ However, the true focus of Best Practices was on how law schools could better design and deliver a curriculum that prepared students for practice. ${ }^{244}$ As the MacCrate Report had done a decade before, Best Practices spoke of the need for skills and values training by calling for "context-based education" as the means for giving students the problem-solving opportunities they need to become competent and effective legal practitioners. ${ }^{245}$ The report also dug into what is wrong with traditional law school teaching and assessment methods, proposing the use of a diversity of approaches that are connected with developing competent and thoughtful practitioners. ${ }^{246}$

school.").

242. See STUCKeY ET AL., supra note 30, at 11-36 (noting a compelling need to improve legal education because, among other reasons: the licensing process is not protecting the public, and because law schools are not fully committed to preparing their students for bar exams or practice).

243. Id.

244. See id. at 8-9 ("Law schools should organize their curriculums to develop knowledge, skills, and values progressively; integrate the teaching of theory, doctrine, and practice; and teach professionalism pervasively throughout all three years of law school.").

245. See id. at 141 ("Legal education would be more effective if law teachers used context-based education throughout the curriculum.").

246. See id. at 207-63 (noting that "many teachers use the case method exclusively even when other methods of instruction would accomplish their educational objectives more effectively," and that "the end-of-the-semester essay exam is an inadequate method for assessing student learning... [that] is 
Overall, the report's core concern was that law schools should recognize the broad array of skills and attributes that successful lawyers need to have beyond legal knowledge and analytical ability and incorporate courses and methods that attend to those competencies. ${ }^{247}$

Following closely on the heels of the Best Practices report in 2007 was another major critique of legal education, a report of the Carnegie Foundation entitled Educating Lawyers: Preparation for the Profession of Law (Carnegie Report). ${ }^{248}$ The report was the product of a two-year study that included an extensive literature review, consultation with the AALS and the Law School Admissions Council, and site visits to a representative sample of sixteen American and Canadian law schools, including public and private schools, more selective and less selective schools, freestanding schools, and schools that served certain ethnic minority groups. ${ }^{249} \mathrm{~A}$ central premise of the Carnegie Report is that the education of professionals is a complex and unique enterprise that cannot simply focus on the transmission of expert knowledge, but must also focus on instilling the specialized skills, standards, judgment, and values that define practice in a profession. ${ }^{250}$ The challenge for professional education is to weave the various components of professional training into a whole that attends to the interests of educators, practitioners, and the public to be served by the profession. ${ }^{251}$

According to the Carnegie Report, this has been the singular challenge of legal education, as its modern linkage with the research university has stood in tension with the historical

neither valid, nor reliable, nor fair").

247. See id. at 7-10 ("While law schools help students acquire some of the essential skills and knowledge required for law practice, most law schools are not committed to preparing students for practice.... [M] ost law school graduates are not as prepared for law practice as they could be and should be.").

248. CARNEGIE REPORT, supra note 22.

249. Id. at $15-16$.

250. See id. at 3-4 (noting that professional schools "are perhaps the sole site where the professions' standards of good work set the agenda for learning").

251. See id. at 4 ("This is a complex educational process... and its value depends, in large part, on how well the several aspects of professional training are understood and woven into a whole."). 
connection between the community of practitioners and young legal apprentices. ${ }^{252}$ The university connection has made legal education predominately academic in character, focusing on teaching and studying law as a science, "put[ting] a premium on formal knowledge, abstracted from context." 253 This positivist orientation-which, as we have seen, characterized the views of Langdell254_-led to a view that the traditions of practice-such as craft, judgment, and professional responsibility-were too subjective and uncritical, a perspective that "undermined the academic legitimacy of practical knowledge" and "spelled the eclipse of traditional forms of practitioner-directed apprenticeship by academic instruction given by scholar-teachers." 255

The triumph of the academy in legal education has resulted in a focus on training in legal knowledge and legal analysis rather than on learning to practice. ${ }^{256}$ Complete professional education, however, must be defined by "three apprenticeships" that the Carnegie Report authors describe: the cognitive apprenticeship focused on expert knowledge and modes of thinking; the apprenticeship of practice, which trains students in "the forms of expert practice shared by competent practitioners;" and the apprenticeship of identity and purpose, which "introduces students to the purposes and attitudes that are guided by the values for which the professional community is responsible." 257 To be successful in their goal of educating lawyers, law schools must "initiate learners into all three apprenticeships." 258 Unfortunately, law schools focus heavily on the cognitive

252. See id. ("[L]aw schools are hybrid institutions. One parent is the historic community of practitioners, deeply immersed in the common law and carrying on traditions of craft, judgment, and public responsibility. The other heritage is that of the modern research university.").

253. Id. at $4-5$.

254. See supra Part II.E (summarizing Langdell's theory of American legal education).

255. CARNEGIE REPORT, supra note 22, at 4-5.

256. See id. at 6-7 ("In its quest for academic respectability, legal education would come to emphasize legal knowledge and reasoning at the expense of attention to practice skills, while the relations of legal activity to morality and public responsibility received even less direct attention in the curriculum.").

257. Id. at 28 .

258. Id. 
apprenticeship: "For many students, neither practical skills nor reflection on professional responsibility figure significantly in their legal education. The academic setting clearly tilts the balance toward the cognitive and intellectual."259 The Carnegie Report contrasts this tilt in legal education with the laboratory experience that characterizes engineering education ${ }^{260}$ and the extensive clinical work that is the hallmark of medical education. ${ }^{261}$

The academic focus of professional legal education has resulted in a shift in teaching methods, away from "apprenticeship, with its intimate pedagogy of modeling and coaching, toward reliance on the methods of academic instruction, with its emphasis on classroom teaching and learning." 262 Further, the Carnegie Report notes that the "signature pedagogy" of law school-the Socratic case-dialogue method-leads to two major weaknesses of typical law school education: "[T]he casual attention that most law schools give to teaching students how to use legal thinking in the complexity of actual law practice" and "law schools' failure to complement the focus on skill in legal analysis with effective support for developing the ethical and social dimensions of the profession."263 These weaknesses "prolong and reinforce the habits of thinking like a student rather than an apprentice practitioner" 264 and leave students with an

259. Id. at 79 .

260. Although engineering education does include lab work, the Carnegie Foundation -in a separate report-has critiqued engineering programs for how labs are poorly designed and integrated into a curriculum that remains dominated by formal knowledge and analysis. SHERI D. ShePPARD ET AL., EDUCATING ENGINEERS: DESIGNING FOR THE FUTURE OF THE FIELD 16, 74 (2009).

261. See CARNEgIE REPORT, supra note 22, at 79-81 ("The distinguishing feature of medical training ... is that most of it is carried out in settings of actual patient care. The consequence is to provide medicine a real advantage, compared to engineering or law, for integrating its forms of apprenticeship."). Clinical clerkships in medical education are a legacy of the Flexner Report, a product of the Carnegie Foundation. See COOKE ET AL., supra note 147, at 13, 82 ("The third year [of medical school], dedicated to patient care and investigation of clinical problems presented by hospitalized patients, is a legacy of the Flexnerian reforms ....").

262. CARNEGIE REPORT, supra note 22, at 25.

263. Id. at 188.

264. Id. 

underdeveloped sense of professional judgment and
responsibility. ${ }^{265}$

Although there have been successful efforts in recent decades to expand practice-oriented education and apprenticeship learning methods in law schools, these experiences tend to be disconnected from the main curriculum, meaning that the three critical elements of legal professionalism-“conceptual knowledge, skill, and moral discernment"266_remain artificially distinct and, thus, are insufficiently transmitted to novice professionals:

[T] he threefold movement between law as doctrine and precedent (the focus of the case-dialogue classroom) to attention to performance skills (the aim of the apprenticeship of practice) and then to responsible engagement with solving clients' legal problems-a back-and-forth cycle of action and reflection-also characterizes most legal practice. The separation of these phases into distinct areas of the curriculum, or as separate apprenticeships, is always an artificial "decomposition" of practice. The pedagogical cycle is not completed unless these segregated domains are reconnected. 267

Ultimately, it is these deficits-insufficient education in the skills and values of professional legal practice, an overuse of the academic case-dialogue method of instruction, and the poor integration of practical and professionalism instruction into the dominant cognitive curriculum-that are contemporary legal education's greatest weaknesses.

Recent studies and practitioner surveys reflect the sense that the Langdellian law school is insufficiently connected with the realities of modern practice. The NALP's After the JD: First Results of a National Study of Legal Careers Survey reports only

265. See id. ("[L]ack of attention to practice and the weakness of concern with professional responsibility-are the unintended consequences of reliance on a single, heavily academic pedagogy to provide the crucial initiation into legal education."); see also id. at 140 ("Insofar as law schools choose not to place ethical-social values within the inner circle... legal education may inadvertently contribute to the demoralization of the legal profession and its loss of a moral compass ....").

266. Id. at 12 .

267. Id. at 124 . 
moderate satisfaction with the level of practice preparedness that law graduates received in law school:

When [survey respondents were] asked to reflect on their legal education, however, most were not especially enthusiastic about the specific role of their law schools in the transition to practice. On the question of whether law school prepared them well for their legal careers, the median response is exactly in the middle (neither agree nor disagree). Respondents tended to agree-but not strongly - with the proposition that law school teaching is too theoretical and unconcerned with real-life practice. They also evinced a desire for more practical training in their assessment of the most helpful law school courses. Both clinical and legal writing courses received higher ratings than more conventional law school offerings. Most helpful in the transition to practice, however, was experience working during law school summers and during the year. ${ }^{268}$

Respondents to the Law School Survey of Student Engagement (LSSSE Survey) corroborate these findings, showing that "[f] orty percent of law students felt that their legal education had so far contributed only some or very little to their acquisition of job- or work-related knowledge and skills." 269

Respondents to the LSSSE Survey also indicated that the Carnegie Report's assessment regarding the insufficient professionalism and ethical training in law schools has some validity: "[O]nly half of students reported that law school prepared them well ... to deal with ethical dilemmas that may arise as part of law practice." 270 Further, survey results showed that clinical participation and pro bono work was correlated with a higher degree of preparation in the areas of "understanding the needs of future clients, working cooperatively with colleagues as part of a legal team, serving the public good through their profession, and understanding professional values that will serve them in their legal careers." ${ }^{271}$. With only a third of law students

268. NALP, AFTER THE JD, supra note 5, at 79.

269. LAW School Survey of Student Engagement, 2011 ANNuAl Survey Results, Navigating Law School: Paths in Legal Education 9 (2011).

270. LaW School Survey of Student Engagement, 2010 ANNUAL SuRvey Results, Student Engagement In LAW School: In Class AND Beyond 8 (2010).

271. Id. 
engaging in clinical work during law school, ${ }^{272}$ these lessons are not being fully diffused across all matriculants. Recent surveys of corporate general counsels confirm the unsatisfactory state of lawyer professionalism; ${ }^{273}$ a majority of those surveyed reported being dissatisfied with outside counsel because of a failure to keep the client adequately informed, non-responsiveness to client interests, making decisions without client authorization, and the failure to give clear advice. ${ }^{274}$

We see, then, that the critique of legal education has a long pedigree, traversing the twentieth century and enduring through the present day. Indeed, the nature of the critique has been remarkably consistent, focusing on the poor connection between traditional legal education and legal practice.

\section{The Current State of Legal Education}

"[T]he [law] schools... must be brought into a closer sympathy and contact with the profession than is now to be found.... It is unjust to students, and a fraud on the public, to recommend them as practitioners until they reach some creditable degree at least of skill and knowledge."

-ABA Comm. on Legal Educ. \& Admission to the Bar, $1879^{275}$

Has contemporary legal education moved beyond this history? Although still fundamentally consonant with the

272. See NALP, 2010 SuRveY of LAW School ExPERIENTIAL LEARNING OPPORTUNITIES AND BENEFITS, supra note 31, at 6 (showing $30.2 \%$ of survey respondents had participated in at least one legal clinic).

273. See, e.g., Comm'n on Professionalism, Ill. Supreme Court, Survey on PROFESSIONALISM 26 (2007), available at http://www.ilsccp.org/pdfs/surveyon professionalism_final.pdf (showing that corporate and in-house counsel reported encountering unprofessional behavior from lawyers).

274. See Clark D. Cunningham \& W. Lee Burge, What Do Clients Want from their Lawyers? 8 (Ga. State Univ. Coll. of Law, Legal Studies Research Working Paper No. 2010-04) (Oct. 13, 2009), available at http://law.gsu.edu/ ccunningham/PDF/WhatClientsWant-130ct09.pdf (reporting unfavorable results pertaining to lawyer professionalism (citing BTI Consulting, How Clients Hire, Fire and Spend: Landing the World's Best Clients (2007), available at http://www.bticonsulting.com/PDFs/HireFireSpend_2007_Executive Summary.pdf)).

275. Hunt, 2 AM. BAR ASS'N REP., supra note 134, at 219. 
Langdellian model, law schools have reformed in many ways since Langdell's time. Professors have varied their teaching methods in ways that build on or depart from the case method. Law schools have pursued and implemented many of the reforms suggested in the reports reviewed above, offering basic legal research and writing training in the first year, ${ }^{276}$ requiring upperlevel extensive writing experiences ${ }^{277}$ in line with the current ABA Standards, ${ }^{278}$ and ensuring that students have some opportunity to experience small class $\operatorname{sizes}^{279}$ and group work with other students. ${ }^{280}$ The relevance of other disciplines to the study of law has been recognized and incorporated into the curriculum through the introduction of interdisciplinary subjects

276. See, e.g., Climenko Fellowship and First-Year Legal Research and Writing Program, HARvard LAw ScH. (Sept. 5, 2012), http://www.law.harvard. edu/academics/degrees/jd/fylrwp/ (last visited Sept. 7, 2012) ("The First-Year Legal Research and Writing Program (LRW) is a series of sequenced, interrelated exercises introducing students to the way lawyers conduct legal research, analyze and frame legal positions, and present their work in writing and in oral argument.") (on file with the Washington and Lee Law Review).

277. See, e.g., JD Writing Requirement, ColumbIa L. ScH., http://www. law.columbia.edu/academics/registrar/writing (last visited Sept. 14, 2012) (describing the details of its J.D. writing requirement) (on file with the Washington and Lee Law Review); Writing Requirement, NYU ScH. OF LAW, http://www.law.nyu.edu/academicservices/degreerequirements/jdprogram/writ ingrequirements/index.htm (last visited Sept. 14, 2012) ("In order to graduate, a student must produce an original analytic paper of substantial length (ordinarily at least 10,000 words in length and undergoes a comment and draft process) under the supervision of a faculty member who may augment these requirements.") (on file with the Washington and Lee Law Review).

278. See 2012-2013 ABA STANDARDS AND RUles OF PROCEDURE FOR APPROVAL OF LAW Schools, supra note 28, Standard 302(a) (requiring "at least one rigorous writing experience in the first year and at least one additional rigorous writing experience after the first year").

279. The Cramton Report noted that some upper-level class sizes are small "simply because they furnish instruction relevant to a less heavily chosen career alternative or are less frequently elected for other reasons" and added that "[t]he instruction can be, but typically is not, significantly different in nature and method from that furnished in large classes." CRAMTON REPORT, supra note 22 , at 23 .

280. See, e.g., Judith Romero, Stanford Law School Advances New Model for Legal Education, SLS NEwS (Feb. 13, 2012), http://blogs.law.stanford.edu/news feed/2012/02/13/stanford-law-school-advances-new-model-for-legal-education/ (last visited Sept. 14, 2012) ("The law school has developed a range of sophisticated team-oriented, problem-solving courses ....") (on file with the Washington and Lee Law Review). 
or the infusion of such learning into traditional law courses. ${ }^{281}$ The clinical legal training movement has successfully imported live-client practice experiences into the law school framework, ${ }^{282}$ affording students the opportunity to opt for such an experience. ${ }^{283}$ And, increasingly, law schools are offering practical skills training courses that teach students the skills they will need to have to practice law. ${ }^{284}$ Indeed, curricular reform is the order of the day, as schools rush to outdo each other in adjusting their programs in various ways to improve their ability to produce practice-capable graduates.

Although these contemporary reforms are appropriate moves in the right direction that will yield results on the margins, to this point, they have not resulted in a wholesale change in the practice-readiness of American law school graduates, a failing that was reflected and explored in the 2007 Carnegie Report and

281. See, e.g., First-Year Curriculum, Academics, NoRThweSTERn UnIv. Sch. OF L., http://www.law.northwestern.edu/academics/jd/1lplan.html (last visited Sept. 14, 2012) (describing "the graduation requirement that every student take at least one course offering an interdisciplinary perspective on law and the legal system") (on file with the Washington and Lee Law Review).

282. See, e.g., Clinics-Lawyering and Learning in the New World, NYU $\mathrm{ScH}$. OF L., http://www.law.nyu.edu/academics/clinics/index.htm (last visited Sept. 14, 2012) (describing its clinical program supported by 15 clinical faculty and 35 clinics) (on file with the Washington and Lee Law Review).

283. Harvard Law School has recently expanded its clinical courses and faculty. See Elana Kagan, The Harvard Law School Revisited, 11 GreEN BAG 2D 475, 480 (2008) ("Over the past five years, we've hired eight new clinical faculty members, and the number of students enrolling in clinical work has more than doubled."). Washington and Lee University School of Law is an example of a school that has broadly embraced extensive experiential learning as a requirement for all of its students. See Washington and Lee School of Law Announces Dramatic Third Year Reform, WASHINGTON \& LeE ScH. OF L. (Mar. 10, 2008), http://www.law.wlu.edu/news/storydetail.asp?id=376 (last visited Sept. 14, 2012) [hereinafter Dramatic Third Year Reform] (on file with the Washington and Lee Law Review). Northeastern University School of Law requires its students to work full time in live-client settings in alternate quarters during the second and third years of law school. See Cooperative Legal Education Program, NorTheastern UnIV. ScH. OF L., http://www.north eastern.edu/law/co-op/ (last visited Sept. 14, 2012) (on file with the Washington and Lee Law Review).

284. See, e.g., Dramatic Third Year Reform, supra note 283 ("Traditional classroom instruction will be replaced by practice simulations, real-client interactions and the development of law practice skills."). 
other recent studies. ${ }^{285}$ Indeed, the numerous shortcomings of the American model of legal education have been documented extensively: Law school does not routinely provide training in many of the practice skill areas-such as drafting, counseling, planning, client development, and client management-needed to be a successful practitioner; 286 only a tiny percentage of law schools require clinical training and the majority of students graduate with no clinical experience; ${ }^{287}$ its primary pedagogical approach (the case-dialogue method) is ineffective ${ }^{288}$ and demoralizing; 289 its main approach to assessment remains the final essay exam, which reflects little about the professional competency of students ${ }^{290}$ and comes too late to allow self-

285. See STUCKEY ET AL., su pra note 30, at 11-13 (explaining that law school programs cannot fully prepare students for law practice and should be viewed as only one step in the training process).

286. See John O. Sonsteng et al., A Legal Education Renaissance: $A$ Practical Approach for the Twenty-First Century, 34 WM. Mitchell L. Rev. 303, 335-37 (2007) (explaining that law schools often graduate unskilled students, who must develop practical skills outside of school and after graduation); see also John M. Burman, Oral Examinations as a Method of Evaluating Law Students, 51 J. LEGAL EDUC. 130, 132 (2001) ("[T] he required curriculum at many, if not most, American law schools virtually ignores at least half of the fundamental skills every lawyer should have.").

287. See NALP, 2010 Survey of LAW School ExPERIENTIAL LEARNing OPPORTUNITIES AND BENEFITS, supra note 31, at 6 (showing $30.2 \%$ of survey respondents had participated in at least one legal clinic, $36.2 \%$ of respondents had taken part in an externship, and $40 \%$ of respondents had taken three or more practice skills courses).

288. See STUCKEY ET AL., supra note 30, at 132-41 (stating that the case method is encumbered with significant problems as an instructional tool, as its impact on students is sporadic, it fails to provide feedback to address skill deficiencies, and it neglects portions of the cognitive process); Bernard D. Meltzer, The University of Chicago Law School: Ruminations and Reminiscences, 70 U. CHI. L. REV. 233, 241 (2003) (arguing that the Socratic method is "notoriously inefficient" at teaching black letter law).

289. See Alan A. Stone, Legal Education on the Couch, 85 HARV. L. REV. 392, 407 (1971) ("Socratic teaching has been attacked as infantilizing, demeaning, dehumanizing, sadistic, a tactic for promoting hostility and competition among students, self-serving, and destructive of positive ideological values.").

290. See Sonsteng et al., supra note 286, at 347 ("The traditional assessment system creates an illusion of higher achievement when there may actually be a deficiency in actual lawyering skills. Professors routinely observe students excel in written exams, but then watch as they struggle with interviewing and counseling clients.”). 
improvement; ${ }^{291}$ faculty incentives promote scholarship over the needs of students; 292 many professors (particularly the more recent ones) have little or even no experience practicing law and lack membership in the bar; ${ }^{293}$ and law school costs so

291. See id. at 337-38 ("[T]he traditional law school model does not provide regular or relevant performance feedback, so students have little opportunity to improve.").

292. See James Lindgren \& Allison Nagelberg, Are Scholars Better Teachers?, 73 CHI.-KENT L. REV. 823, 827-29 (1998) (explaining data showing that major scholars, despite teaching larger and more classes, are perceived as better teachers than less-cited scholars); see also Deborah Jones Merritt, Research and Teaching on Law Faculties: An Empirical Exploration, 73 CHI.KENT L. REV. 765, 807 (1998) (showing that faculty who taught at prestigious universities taught fewer credit hours than faculty at less prestigious institutions); Fred R. Shapiro, They Published, Not Perished, But Were They Good Teachers?, 73 CHI.-KENT L. REV. 835, 839 (1998) (observing that "while, generally, praise of teaching is a nearly universal feature of tributes to law faculty, for the most highly cited scholars, it is often completely absent from their tributes, and this despite the fact that such scholars typically are accorded much longer tributes than is the norm").

293. A review of the faculty profiles at the more "elite" law schools reveals faculty members who have doctoral degrees in other disciplines but have no practice experience whatsoever, which cannot put such faculty in a strong position to train their students in the skills needed for practice. See Joni Hersch \& W. Kip Viscusi, Law and Economics as a Pillar of Legal Education 2-4 (Vanderbilt Univ. Law and Econ., Working Paper No. 11-35, 2011), available at http://papers.ssrn.com/sol3/papers.cfm?abstract_id=1907760\#. A 2003 study based on AALS data revealed that for those law professors hired between 1996 and 2000 , of those with any practice experience ( $86.6 \%$ of the hires), the average number of years of experience was 3.7. Richard E. Redding, Where Did You Go to Law School? Gatekeeping for the Professoriate and its Implications for Legal Education, 53 J. LEGAL EDUC. 594, 601 (2003); see also Harry T. Edwards, A New Vision for the Legal Profession, 72 N.Y.U. L. REV. 567, 571 (1997). Edwards notes:

[A] number of young lawyers flee the 'rat race' after only a short stay. Often, very bright young lawyers seek to move from law practice to law teaching as quickly as possible, with little practical knowledge or professional experience. This creates a conundrum whereby many of these smart young people who escape to academia have nothing good to say about practice, though they are the 'teachers' of the next generation of the legal profession.

Id.; see also Ann Juergens, Using the MacCrate Report to Strengthen Live-Client Clinics, 1 CLINICAL L. REv. 411, 412-13 (1994) ("[An] excellent academic record at an 'elite' law school, law review, clerkship for an appellate judge, perhaps a few years at a big law firm, but relatively little first-hand knowledge of dealing with clients, transactions, the courtroom, real-life conflict and problem solving."). 
much $^{294}$ that most graduates have mammoth, mortgage-like debts that limit their economically viable options after graduating. ${ }^{295}$ This is no way to produce competent legal professionals. A closer look at some of the pillars of law school education-its curriculum, its pedagogy, its assessment methods, and its faculty-reveal that what is past is not only prologue, but it is largely our present, a fact that is problematic given the death of the apprenticeship and the dramatic changes in the law and legal practice since the time of Langdell.

\section{A. The Curriculum}

Contemporary law school curricula are dominated by legal doctrine, as was the case during the nineteenth century. Currently, law school is typically a three-year program (when pursued full-time) ${ }^{296}$ that offers roughly the same basic set of

294. Average private law school tuition in 2009 was $\$ 35,743$, while in-state tuition at public law schools averaged \$18,472. Am. B. Ass'n, Law School Tuition 1985-2009, at 1, 3, http://www.americanbar.org/content/dam/aba/ administrative/legal_education_and_admissions_to_the_bar/statistics/s_tuition. authcheckdam.pdf.

295. Am. B. Ass'n, Average Amount Borrowed for Law School 2001-2010 at 1, http://www.americanbar.org/content/dam/aba/administrative/legal_education_ and_admissions_to_the_bar/council_reports_and_resolutions/2001_2010_avg_a mt_borrowed.pdf.

296. Northwestern offers an exception with its two-year Accelerated J.D. Program. See Accelerated JD, NorThwestern UNIV. Sch. OF L., http://www.law.northwestern.edu/academics/ajd/ (last visited Sept. 1, 2012) (outlining the requirements of the accelerated two-year J.D. program) (on file with the Washington and Lee Law Review). The University of Dayton School of Law offers a two-year option as well. See Two-Year Juris Doctor Program, UNIV. OF DAYTON ScH. OF L., http://www.udayton.edu/learn/law/juris_doctor_two_ year_option.php (last visited Sept. 1, 2012) (on file with the Washington and Lee Law Review). Part-time programs tend to run four years. See, e.g., Full-and Part-Time Programs, GeORge Washington UnIV. L. Sch., http://www. law.gwu.edu/Admissions/JD/Pages/ FT_PT.aspx (last visited Sept. 14, 2012) (“A part-time student normally will take eight semesters, or four academic years, and one summer session [to complete the JD degree].") (on file with the Washington and Lee Law Review); Part-Time Program, Georgetown UnIV. L. CTR., http://www.law.georgetown.edu/academics/academic-programs/jd-program/ part-time-program/index.cfm (last visited Sept. 14, 2012) ("The part-time program is designed to allow part-time students to complete the J.D. degree requirements in eight academic semesters.") (on file with the Washington and 
first-year doctrinal courses ${ }^{297}$-featuring traditional common law subjects ${ }^{298}$ _ and legal research and writing instruction, followed by electives that offer doctrinal, skills, or professional/clinical instruction at the election of the student, culminating with a major writing requirement of some kind. ${ }^{299}$ Students generally are not required to take particular courses beyond the first year 300 _professional responsibility or "PR" being a typical exception ${ }^{301}$ nor is their course load typically organized around tracks or concentrations, though many schools do offer the option

Lee Law Review).

297. Virtually every American law school requires the following courses in the first year of study: contracts, torts, property, criminal law, and civil procedure. SEc. OF Legal EdUC. \& Admission to the BAR, AM. B. Ass'N, A SuRveY OF LAW School CuRricula 25 (2004) [hereinafter 2004 SURveY OF LAW School CURRICUIA]. Law schools vary in the courses they require in the first year beyond this basic diet, with many requiring additional doctrinal courses like constitutional law, administrative law, or transnational law, and some requiring practically-oriented courses focusing on lawyering or problem solving skills. See, e.g., Problem Solving Workshop, HaRvard L. ScH. (Dec. 21, 2009), http://www.law.harvard.edu/academics/registrar/winter-term/problem-solvingworkshop.html (last visited Sept. 14, 2012) (on file with the Washington and Lee Law Review).

298. The common law focus of the first-year curriculum is an inheritance from Langdell, who believed that the common law was the core feature of the American legal system, representing a coherent set of enduring principles that transcended politics and provided a rational guide for human behavior. See Rubin, supra note 101, at 624, 626.

299. Supra notes 276-78 and accompanying text.

300. See, e.g., Second and Third Year Curriculum, NoRTHWESTERn UNIV. SCH. OF L., http://www.law.northwestern.edu/academics/jd/2l_3lplan.html (last visited Sept. 14, 2012) ("After first year, your educational plan is largely in your hands as there is only one mandatory class. You must take Legal Ethics, but all other courses are elective.") (on file with the Washington and Lee Law Review); The Program-Courses-Overview, STANFORD L. ScH., http://www. law.stanford. edu/courses/ (last visited Sept. 14, 2012) ("During the second and third year of law school students are encouraged to follow an academic curriculum customized to their individual interests.") (on file with the Washington and Lee Law Review).

301. The ABA Standards impose a requirement of giving students some legal ethics or professionalism training. 2012-2013 ABA STANDARDS AND RILES OF PROCEDURE FOR APPROVAL OF LAW SCHOOLS, supra note 28, Interpretation 302-9 ("The substantial instruction in the history, structure, values, rules, and responsibilities of the legal profession and its members required by Standard 302(a)(5) includes instruction in matters such as the law of lawyering and the Model Rules of Professional Conduct of the American Bar Association."). 
of pursuing courses within a specified area of focus. ${ }^{302}$ Although experiential learning is becoming something that many law schools are requiring students to have at least one encounter with, ${ }^{303}$ few schools require extensive practical skills and clinical training. ${ }^{304}$ Under this traditional approach, the primary focus within the law school curriculum is on doctrinal courses and the

302. Many schools offer the opportunity to pursue a concentration, which may or may not lead to a certification to that effect. See, e.g., Programs of Study, HARVARD L. SCH. (Aug. 31, 2012), http://www.law.harvard.edu/academics/ degrees/jd/pos/index.html (last visited Sept. 14, 2012) (on file with the Washington and Lee Law Review). Harvard explains:

To guide you in pursuing deepening knowledge and progression as you move through the three years of law school and to create a tool for better coordination and collaboration between faculty members, the faculty has developed 'programs of study.' Students do not sign up for any program; nor should any student feel compelled to adhere to one.

Id. However, the author is unaware of any school that requires all of its students to organize their courses around a substantive concentration.

303. For example, Gonzaga University School of Law imposes what they call an "Experiential Learning Requirement," which they describe as "a capstone experience" completed through a clinical course or an externship. Curriculum, GONZAGA UNIV. ScH. OF L., http://www.law.gonzaga.edu/Academic-Program/ curriculum/default.asp (last visited Sept. 14, 2012) (on file with the Washington and Lee Law Review); see also, e.g., Clinics, UnIV. OF CAL., IRvine SCH. OF L., http://www. law.uci.edu/clinics/index.html (last visited Sept. 14, 2012) ("Prior to graduation, each student will complete at least one semester of clinical education....") (on file with the Washington and Lee Law Review); The Lawyering Program, NYU ScH. OF L., http:/www.law.nyu.edu/academics/ lawyeringprogram/index.htm (last visited Sept. 14, 2012) ("Lawyering introduces first-year students to the skills and the theory of the law in use through two semesters of simulated exercises in legal problem solving.") (on file with the Washington and Lee Law Review). Data from a 2004 ABA report indicate that at that time, only $29 \%$ of law schools responding to a survey required some form of skills, clinical, or simulation course for graduation. 2004 SURVEY OF LAW SCHOOL CURRICUIA, su pra note 297, at 20.

304. Exceptions, of course, do exist and were mentioned previously. See supra note 283 and accompanying text (discussing experiential learning opportunities at Washington and Lee and Northeastern). Gonzaga University School of Law provides more practical skills training than is typical by supplementing its basic first-year legal research and writing courses with a "Litigation Skills \& Professionalism Lab" (the life of a case) in the fall and a "Transactional Skills \& Professionalism Lab" (the life of a commercial transaction) in the spring. Course Descriptions and Frequency, Gonzaga UnIV. ScH. OF LAw (Spring 2010), http://www.law.gonzaga.edu/files/coursedescriptions.pdf. 
transmission of substantive knowledge, with experiential or clinical courses aimed at transmitting practice skills being elective offerings ${ }^{305}$ mostly taught by a separate group of faculty members (clinical or adjunct professors) with different titles and status. ${ }^{306}$

This focus on academic instruction is a legacy of the importation of legal education into the traditional university and the desire of early reformers such as Langdell and Harvard's President Eliot, ${ }^{307}$ and later the $\mathrm{ABA}$ and the Association of American Law Schools, ${ }^{308}$ to raise the standards and status of legal education from its apprenticeship roots. ${ }^{309}$ One consequence of this doctrinal approach is that the study of law is conceptualized as the study of legal rules-a Langdellian innovation ${ }^{310}$-rather than a broader study of legal practice

305. See CARNEGIE REPORT, supra note 22, at 87 ("These lawyering courses cover a wide range, from research and legal writing in the first year, through trial advocacy and practice negotiation to clinical experience with actual clients. Typically, these are elective courses, optional for students.").

306. See id. at 87-88 ("[T]hey are most of ten taught by faculty other than those teaching the so-called substantive or doctrinal courses of the curriculuma faculty that is not typically tenured and that has lower academic status.").

307. See su pra Part II.E. President Eliot once remarked that "law is to be learned almost exclusively from the books in which its principles and precedents are recorded, digested, and explained," not from "the court or the law office." 1 WARREN, HISTORY OF THE HARVARD LAW SCHOOL, su pra note 54, at 391-92.

308. See infra Part III.C; CARNEGIE REPORT, su pra note 22, at 93

Today's standard model-the three-year curriculum, an emphasis on analytical training through the case-dialogue method, and work on a law review journal-took a long time to achieve dominance in preparation for legal practice. This model was promoted by the American Bar Association and the Association of American Law Schools as a way to raise standards, in order to protect the public and, not incidentally, to enhance the status of the profession.

See also BlaCKSTONE, supra note 39, at *33 ("The inconveniences [of an exclusively apprenticeship-based legal education] can never be effectually prevented, but by making academical education a previous step to the profession of the common law ....").

309. Supra notes 256-58 and accompanying text.

310. See supra notes 97-103 and accompanying text (explaining Langdell's belief that law is most effectively taught through the study of legal principles in their purest form: as they appear in court opinions); see also John Henry Schlegel, Walt Was Right, 51 J. LEGAL EDUC. 599, 600 (2001) ("[W]ere Langdell to reflect on modern casebooks ... he [would] recognize] that the essential substance of these newfangled books was the same as in his first casebook, the 
involving the study of legal regulation as a social phenomenon ${ }^{311}$ and training in the full array of methods and techniques that legal practitioners must be able to employ. Another consequence of this academic, doctrinal dominance is that law faculties built to deliver such curricula tend not to consist of experienced practitioners but rather career academics focused on legal scholarship. ${ }^{312}$

However, as the 2007 Carnegie Report and other reports and commentators have emphasized, substantive legal knowledgealthough a critical element of professional training-is not the sole or principal component of learning to be a practicing lawyer, ${ }^{313}$ nor is it realistic to expect that law school can impart the sum total of substantive knowledge needed for practice. ${ }^{314}$ To the contrary, there are several related but distinct levels of training that are necessary to become a competent legal professional: the acquisition of foundational knowledge and analytical abilities, the development of certain practical skills, and the formation of the professional values and judgment that define legal practice. ${ }^{315}$ The traditional law school curriculum

one on contracts - the patient explication of legal doctrine, the rule of law as the law of rules.").

311. See Rubin, supra note 101, at 640 ("[S]ocial science has taught us to regard law as a social practice.... While law ... may be understood as definitive statements by authoritative sources, legal practice is the total set of behaviors that are prevalent among those trained professionals.").

312. See Jean R. Sternlight, Symbiotic Legal Theory and Legal Practice: Advocating a Common Sense Jurisprudence of Law and Practical Applications, 50 U. MIAMI L. REV. 707, 712 (1996) ("[L]aw schools are often highly reluctant to hire 'the practitioner,' and . . particularly at elite law schools, professors of ten sneer at books and articles oriented toward practice, doctrine or (perhaps worse) teaching." (citation omitted)).

313. See CARNEGIE REPORT, supra note 22, at 25-29 (describing necessary components of legal education that are lacking in the current system).

314. See Karl N. Llewellyn, The Bramble Bush: Some Lectures on Law AND ITS STUDY 93 (1930) ("No, the nature of our system of multiple jurisdictions, the accidental constellation of our statutes, the inductive concrete method of our case-materials-these make the learning of our law entire, as information, hopeless."(emphasis added)); see also Frank, Why Not a Clinical LawyerSchool?, supra note 204, at 726 ("Of course it is impossible in three years, or indeed in thirty-three years, to give or take courses in all the subjects into which the subject we call 'law' can be subdivided.").

315. See CARNEGIE REPORT, supra note 22, at 27 ("For the sake of their 
does not reflect the relative importance of each of these levels of learning because it focuses the lion's share of attention on doctrinal instruction. ${ }^{316}$ Fixing that imbalance does not mean that law school should be entirely handed over to "vocational" or skills training, the reflexive critique seemingly lodged at any effort to make legal education more relevant to legal practice. ${ }^{317}$ Rather, it means that the current relationship between doctrinal, practical, and professional instruction must become more integrated and balanced: Skills-based and practice-centered instruction and training should be a more substantial part of the law school experience, with substantive knowledge instruction serving as the foundation for and compliment to practical professional education. Further, to facilitate the transition from student to practitioner, doctrinal instruction must move more quickly into being taught in context from the operational perspective, ${ }^{318}$ rather than more abstractly through the prism of judicial opinions and the case method. ${ }^{319}$ Finally, students must

future practice, students must gain a basic mastery of specialized knowledge, begin acquiring competence at manipulating this knowledge under the constrained and uncertain conditions of practice, and identify themselves with the best standards and in a manner consistent with the purposes of the profession."); see also Lon L. Fuller, What Law Schools Can Contribute to the Making of Lawyers, 1 J. LEGAL EDUC. 190, 193-95 (1948-1949) (arguing that the current method of legal education is ineffective because it only focuses on one form of adjudication, the appellate decision, while neglecting all other forms of adjudication, as well as the entire legislative process).

316. See Margaret Martin Barry et al., Clinical Education for This Millennium: The Third Wave, 7 ClinICAL L. REv. 1, 32 (2000) ("The analysis of legal doctrine as presented in appellate decisions digested in casebooks... continues to frame most classroom discourse ....").

317. See BlaCKSTONE, supra note 39 , at *32 ("If practice be the whole he is taught, practice must also be the whole he will ever know: if he be uninstructed in the elements and first principles upon which the rule of practice is founded, the least variation from established precedents will totally distract and bewilder him."); see also Fuller, supra note 315 , at 191 ("[A]s soon as an attempt is made to employ the skills-and-techniques conception as the exclusive standard for organizing legal education, the whole educational process is disoriented and cheapened.").

318. Kristen Holmquist refers to this as "applied learning opportunities." Kristen Holmquist, Challenging Carnegie, 61 J. LEGAL EDUC. 353, 357 (2012).

319. See STUCKEY ET AL., supra note 30, at 99 ("Law schools cannot prepare students for practice until they teach doctrine, theory, and practice as part of a unified, coordinated program of instruction."). 
have more opportunities to collaborate in team settings and to work on solving problems that blend legal and other issues in a single setting. ${ }^{320}$ Many law schools seem to be making moves in these directions, ${ }^{321}$ though how thorough and effective these changes will be at each school remains to be seen.

\section{B. The "Signature Pedagogy" of Law School}

"[I]t is obvious that man could hardly devise a more wasteful method of imparting information about subject matter than the case-class."

-Karl Llewellyn, 1948-1949322

Although the case-dialogue method has been criticized and modified in many ways over the years, ${ }^{323}$ it retains its basic hold as the fundamental framework for teaching law students legal doctrine and analysis to this day. ${ }^{324}$ Indeed, notwithstanding the

320. See Michael Hunter Schwartz, Sophie Sparrow \& Gerald Hess, Teaching Law By Design: Engaging Students from the Syllabus to the FINAL EXAM 7 (2009) ("Students engage in crucial mental activity when they negotiate meaning and seek to synthesize their personal understandings. The hundreds of studies demonstrating the superiority of cooperative learning groups compared to all other teaching methods support this assertion.").

321. See, e.g., Romero, supra note 280 (announcing that Stanford Law School is "transforming its traditional law degree into a multi-dimensional J.D., which combines the study of other disciplines with team-oriented, problemsolving techniques together with expanded clinical training that enables students to represent clients and litigate cases while in law school").

322. Llewellyn, The Current Crisis in Legal Education, supra note 212, at 215.

323. See, e.g., CARNEGIE REPORT, supra note 22, at 56-59 (describing the case-dialogue method as insufficiently connected with practical context and

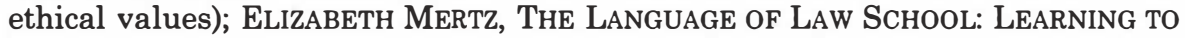
"THINK LIKE A LAWYER" 190, 202 (2007) (explaining that the current methods used in law schools to get students "thinking like lawyers" have disparate effects depending on students' race and gender); REDLICH, supra note 95 (criticizing the case method for failing to give students a picture of the law in its entirety); STUCKEY ET AL., su pra note 30, at 41-47, 132-34 (noting the negative impacts of the case-dialogue method on the students' education).

324. See CARNEGIE REPORT, supra note 22, at 50 ("[L]aw schools use casedialogue teaching almost exclusively in the first phase of doctrinal instruction."); see also MERTz, supra note 323, at 41 (describing the Socratic method of teaching as the "discourse for which law school is famous"). Edward Rubin has 
myriad changes in the legal profession and in our understanding of how people learn, ${ }^{325}$ the contemporary law school remains remarkably Langdellian ${ }^{326}$ in its design as a three-year system in which doctrinal legal knowledge and legal analytical abilities are transmitted to students mostly via a traditional or modified casedialogue approach, ${ }^{327}$ supplemented with optional or mandatory experiential learning components. ${ }^{328}$ It must be acknowledged, however, that most professors vary from a pure Socratic method in their doctrinal courses, ${ }^{329}$ and that the method has virtually no place in experiential courses. ${ }^{330}$ Thus, it would simply be

written that the case method has reached venerated status, making any critiques a threat to an esteemed tradition:

Continuing on for another seventy years or so, [the Langdellian model] has ceased to be viewed as a particular approach to legal education-as last generation's innovation-and has become a venerable institution that gains gravity and prestige from its antiquity. As such, this approach has the remarkable capacity to make suggested changes seem jejune and to reduce reform initiatives to quixotic ventures that can be dismissed with knowing guffaws from its wiser, more experienced supporters.

Rubin, supra note 101, at 613.

325. See infra notes 350-53 and accompanying text (explaining and differentiating learning techniques).

326. See Llewellyn, The Bramble Bush, supra note 314, at 145 ("Our teaching technique we have ... carried for the most part unaltered into wholly changed conditions ...."); see also Todd D. Rakoff \& Martha Minow, A Case for Another Case Method, 60 VAND. L. REV. 597, 597 (2007) ("The plain fact is that American legal education, and especially its formative first year, remains remarkably similar to the curriculum invented at the Harvard Law School by Christopher Columbus Langdell over a century and a quarter ago." (citation omitted)).

327. See Rubin, supra note 101, at 610 ("[T]he basic educational approach that law schools use remains essentially unchanged from the one that C.C. Langdell introduced at Harvard in the years following the Civil War.").

328. See CARNEGIE REPORT, su pra note 22, at 34-43 (describing programs at NYU and CUNY designed to provide students with practical, hands-on legal experience during law school).

329. See MERTZ, supra note 323, at 142 (indicating that "pure" Socratic teaching was encountered in only one class within the study); see also id. at 142-69 (describing variations of the Socratic teaching style as "pure" or "traditional," "modified," a mixed method of "dialogue, lecture, and conversation," and a "dialogic" lecture method).

330. See CARNEGIE REPORT, supra note 22, at 59 ("[C]ase-dialogue teaching is seldom explicitly connected with clinical teaching ...."). 
inaccurate to characterize all of law school education as merely a sequence of ineffectual classically Socratic experiences. That said, it is true that traditional doctrinal courses-which do in fact dominate the curricula at virtually all law schools-tend to involve the study of doctrine through the lens of cases and casebooks ${ }^{331}$ _even in statutory courses ${ }^{332}$ _and that professors typically use a mix of lecture and Socratic questioning as the principal means of covering the material in their courses throughout law school. 333

While there may be strengths to the case-dialogue method, ${ }^{334}$ there are several shortcomings worth noting here. It is often said that the virtue of the case method is the training it can impart in the skills of legal reasoning and analysis-"thinking like a lawyer"-that are critical components of professional

331. See id. at 55 ("The legal texts that form the basis for the case-dialogue method are found in a unique invention of legal pedagogy-the case book."). The material used in a typical doctrinal law school course is some variant of a casebook-a text collecting edited cases organized by topic and supplemented with notes and questions-rather than a legal treatise or traditional textbook of the kind found in other disciplines such as biology, history, or accounting. The inclusion of such "materials" (notes, questions, article excerpts, etc.) in modern casebooks is what distinguishes them from the very first casebook, which was developed by Langdell himself and solely consisted of cases organized by the legal principles to which they related. See C. C. LANGDELL, SELECTION OF CASES ON THE LAW OF CONTRACTS (Neil H. Alford, Jr. et al. eds., The Legal Classics Library 1983) (1871).

332. See, e.g., Thomas D. Morgan, CASES AND Materials ON Modern ANTITRUst LAW AND ItS ORIgins (2009); SAMUEL Estreicher \& Michael C. HARPER, CASES AND MATERIALS ON EMPLOYMENT DisCRIMINATION LAW (2008).

333. See CARnEgie RePort, supra note 22, at 3 ("Law schools use Socratic case-dialogue instruction in the first phase of their students' legal education. During the second two years, most schools continue to teach, by the same method, a number of elective courses in legal doctrine."); see also MERTZ, supra note 323, at 144-69 (finding, among the classrooms contained in the study, that most professors used variations of the Socratic method that blended questioning about cases with discussion and lecture).

334. Rakoff \& Minow, supra note 326, at 598

The Langdellian case method afforded a way to communicate information; to cultivate a style of reasoning and questioning that was intellectually respectable, yet also well-suited to the paradigmatic law practice of adjudication; and to engage the attention and interests of large numbers of students at relatively little expense for instruction and materials. 
development. 335 These are skills that all law students must acquire if they are to become fluent in the language of the law, jurisprudence, and the art of using cases to derive and develop legal principles. ${ }^{336}$ However, the ability of the case-dialogue method to transmit analytical skills effectively has never been demonstrated. Indeed, Elizabeth Mertz, in her seminal study of the case method, The Language of Law School, describes studies of teaching methods that fail to show any connection between the method used and the ability of students to engage in effective legal analysis. ${ }^{337}$ Additionally, the type of thinking promoted by the method is limited to certain kinds of legal analysis, neglecting some of the basic problem-solving skills that today's practitioners need to develop solutions to their clients' problems. ${ }^{338}$

335. See, e.g., CARNEGIE REPORT, supra note 22, at 53 (describing the "deep structure" of the case-dialogue pedagogy as "the teaching of legal reasoning"); $i d$. at 54 (indicating that the "dispositions and attitudes" modeled by the casedialogue pedagogy are "habits of legal thinking" such as distancing from extraneous detail to focus on points of legal argument); CRAMTON REPORT, supra note 22 , at 13 ("The traditional 'socratic method' of legal instruction continues to be used in first year law classes as an extremely effective technique for developing analytical skills ...."); LlEWELlyn, The BRAMBLE BUSH, supra note 314 , at 116 ("The first year ... aims, in the old phrase, to get you to thinking like a lawyer."'); but see Rubin, supra note 101, at 610-11

What one sometimes hears is that the current law school curriculum teaches students to 'think like lawyers.' Any systematic demonstration that such an outdated approach to legal education develops skills that are central to the very different world of modern legal practice would be interesting to see, but no such demonstration has been offered. (citation omitted).

336. See, e.g., Frank, Why Not a Clinical Lawyer-School?, supra note 204, at 910 (" $[\mathrm{N}] \mathrm{o}$ sane person will deny that a knowledge of those rules and principles, of how to 'distinguish' cases, and of how to make an argument as to the true ratio decidendi of an opinion, is part of the indispensable equipment of the future lawyer.").

337. See MERTZ, supra note 323, at 28 ("[C]ontrolled experiments in which first-year classes were divided into separate groups, some taught Socratically and others not, resulted in generally similar performances." (citing Edward Kimball \& Larry Farmer, Comparative Results of Teaching Evidence Three Ways, 30 J. LEGAL EDUC. 196, 196-212 (1979); Willard Lorenson, Concentrating on a Single Jurisdiction to Teach Criminal Law-An Experiment, 20 J. LEGAL EDUC. 361, 361-65 (1968))).

338. See Kagan, supra note 283, at 477 ("[W]hile the case method does a great job teaching students a certain type of legal reasoning, it fails to equip them fully to serve as active problem solvers, able to engage a range of resources 
Another weakness of the case-dialogue method, as currently employed in law schools, is that whatever benefits might accrue from the method are difficult to achieve among large groups of students. When the method is used in the context of large classes - which is typical ${ }^{339}$ - it tends to focus attention on a discussion between a few students and the professor. ${ }^{340}$ Although the students involved may benefit to some extent, the method is less effective in instilling legal analytical skills vicariously to observers not involved in the discussion, ${ }^{341}$ creating diminishing returns as the class grows in size. ${ }^{342}$ Relatedly, large classes conducted under the Socratic method involve sizeable audiences of peer onlookers, potentially contributing to the stress and anxiety of students expected to respond to the professor's questioning ${ }^{343}$ and creating an intimidating environment that

and strategies to come up with creative solutions.").

339. See MERTZ, supra note 323, at 7 ("Although many law schools are now experimenting with smaller first-year classes, it is still common to find the bulk of a first-year student's time spent in larger classes of seventy to one hundred students."); $i d$. at 202 (identifying patterns in her study linking "increased class participation and classroom presence with traditional insiders...; that is, white male students tend to predominate."); id. at 177 ("Use of recitation (the closest analogue to Socratic dialogue), with its intensely public potential for evaluation of responses (both by teachers and peers), tends to encourage the formation of entrenched, segregated groups." (citing STEVEN BOSSERT, TASKS AND SOCIAL RELATIONS IN ClassRoOMS: A STUDY OF INSTRUCTIONAL ORGANIZATION AND ITS CONSEQUENCES (1979))).

340. See Michael Hunter Schwartz, Teaching Law by Design: How Learning Theory and Instructional Design Can Inform and Reform Law Teaching, 38 SAN DIEGO L. REV. 347, 351 (2001) ("[L]aw professors structure classroom interactions as one-on-one, professor-on-student dialogues.").

341. See STUCKEY ET AL., supra note 30, at 222 ("[I]nevitably, many students have not participated in the dialogue; some, overwhelmed by the relief that they were not the one called on, have not even listened attentively." (citation omitted)); Schwarz, supra note 340, at 351 ("[L]aw teaching requires students to learn vicariously.").

342. See STUCKEY ET AL., supra note 30, at 134 ("The potential value of the Socratic dialogue and case method is diminished, however, because we use it in large classroom settings ....").

343. See Jennifer Jolly-Ryan, The Last Taboo: Breaking Law Students with Mental Illnesses and Disabilities Out of the Stigma Straitjacket, 79 UMKC L. REV. 123, 144 (2010) ("[D]ue to the nature of a legal education, such as stress, competition, and longstanding traditions including the Socratic Method and grading policies, depression and anxiety may develop."); see also Lawrence Silver, Comment, Anxiety and the First Semester of Law School, 1968 WIS. L. 
may be more discouraging to women ${ }^{344}$ and students of color. ${ }^{345}$ These dual challenges surrounding the use of the method in large groups indicate that law schools take what theoretically may be a sound pedagogical approach and dilute it, suggesting that moving the Socratic case-dialogue out of the large classroom into a much smaller setting with only a handful of students might be a structural alteration that would allow the approach to bear its fullest fruit.

Next, the case-dialogue method is an inefficient means of transmitting substantive information and is limited in its ability to impart the full range of competencies that students need to become successful legal professionals. 346 There have been many advances in learning theory and pedagogy since Langdell's time with which the case-dialogue method is out of step. ${ }^{347}$ Yet the

REV. 1201, 1203-05 (describing the anxiety inducing effects of the Socratic method).

344. See MERTZ, supra note 323 , at 190 ("Our data tend to confirm the findings of previous studies ... that male law students generally participate at greater rates than females."); see also LANI GUINIER, MICHELlE FINE \& JANE BALIN, BeCOMING GeNTlEMEN: Women, LAW SCHOOL, AND INSTITUTIONAL CHANGE 49 (1997) ("The pedagogical structure of the first year-large classes, often constrained by limits on student participation, fierce competition, a mandatory grading curve, and few women faculty-produces alienation and a genderstratified hierarchy.").

345. See Carol J. Buckner, Realizing Grutter v. Bollinger's "Compelling Educational Benefits of Diversity"-Transforming Aspirational Rhetoric into Experience, 72 UMKC L. REV. 877, 911 (2004) ("The academic achievement of African American students improves when teachers use cooperative rather than competitive learning strategies ...." (citation omitted)); see also id. at 905

Hispanic students do not like to be singled out; they function more effectively working in groups to achieve a common goal and are receptive and susceptible to thoughts and attitudes expressed by others. Encouragement, group work and establishing a sense of belonging' all help to create a positive learning experience for Hispanic students. These learning preferences describe the direct antithesis of the typical law school environment, and explain the dysfunction and disparate achievement of Hispanic students. (citations omitted).

346. See CARNEGIE REPORT, supra note 22, at 58-59 ("[L]earning the law is an ensemble experience.... [T'] he apprenticeships of cognition, performance, and identity are not freestanding ... . Because case-dialogue teaching is seldom explicitly connected with clinical teaching, few law schools achieve the full impact that an integrated ensemble could provide.").

347. See Schwarz, supra note 340 , at 383 
Langdellian case-dialogue method-a relic of a bygone era ${ }^{348}$ persists. ${ }^{349}$ Insights from learning theory reveal that teaching focused mainly on purely abstract concepts divorced from their context-something that fairly characterizes the case method-is less effective than teaching that recognizes that we experience information in many different ways and at different levels of abstraction. Edgar Dale visualized these various levels of encountering information with his Cone of Experience, which depicted "a range of experience from firsthand action to observation (iconic experiences) on to symbolic communication." 350 For example, one can understand what a knot is directly by tying the knot (referred to by Dale as an "enactive" experience), visually by simply seeing a picture of a knot (an "iconic" experience), or abstractly by simply hearing or seeing the word "knot" or a verbal description of the phenomenon (a "symbolic" experience). ${ }^{351}$ Learning often moves from direct experience or iconic experience toward abstractions as words or symbols whose meaning we come to understand, ${ }^{352}$ although this

All three learning theories discussed-behaviorism, cognitivism, and constructivism-are relevant to law school instruction, yet, for the most part, the legal academy has ignored these theories. Together, the theories suggest that instruction should cause students both to build their skills from base levels to the highest levels, and to move from simply knowledge of information to the creative problem-solving contemplated by the constructivist model.

348. See Rubin, supra note 101, at 611 ("Langdell's design for legal education, although innovative in its own time and on its own terms, is more closely connected to modes of thought that prevailed in the Renaissance, the Middle Ages, and ancient Greece and Rome than to our current ways of thinking.").

349. See MERTZ, supra note 323, at 26 ("[D]espite a number of arguably successful attacks on the substantive underpinnings of Langdell's approach, the method itself appears to have outlasted its theoretical rationale.").

350. Edgar Dale, Audiovisual Methods in Teaching 110 (3d ed. 1969). The levels of the Cone, from bottom to the top, are direct purposeful experiences, contrived experiences, dramatized experiences, demonstrations, study trips, exhibits, educational television, motion pictures, recordings, radio and still pictures, visual symbols, and verbal symbols. See id. at 107 (illustrating the eleven levels of Dale's "Cone of Experience").

351. Id. at 108. Dale borrows these terms from JEROME S. BRUNER, TOWARD A THEORY OF INSTRUCTION, 10-11 (Harvard Univ. 1966).

352. Id. at $108-09$. 
is not always the case. ${ }^{353}$ However, when learning consists solely of abstractions untethered from lower-order experience, problems can arise:

Difficulties arise when abstractions have inadequate foundations. If a learner has had too little enactive or iconic experience in acquiring a particular summarizing idea, the word or formula will probably have no real meaning for him. Because a verbal symbol does not resemble anything the [student] can do or see, he may have difficulty in relating it to his own experience. If a symbol is to stand for something, it must stand on something-a firm foundation of relevant experience. ${ }^{354}$

This is not to say that enactive or iconic experiences must always precede abstract learning; ${ }^{355}$ rather, abstract learning can be enhanced by direct or visual experiences that can concretize and deepen the understanding of the abstract concept at issue. ${ }^{356}$

The application of Dale's insights to legal education is clear: Law school learning exclusively rooted in symbolic, abstract experience is less likely to be effective in giving students the depth of understanding requisite for moving towards proficient legal practice. Further, to the extent that legal learning is exclusively at the abstract level, it becomes difficult for students to synthesize learning from different areas or to operationalize concepts for practical application and the resolution of real-world legal problems. ${ }^{357}$ To be clear, this is not an argument that the

353. See id. at 128 ("Does the Cone device mean that all teaching and learning must move systematically from base to pinnacle? Emphatically no .... . We continually shuttle back and forth among various kinds of experiences.").

354. Id. at 109 .

355. See id. at 128-29

In our teaching, then, we do not always begin with direct experience at the base of the Cone. Rather, we begin with the kind of experience that is most appropriate to the needs and abilities of a particular learner in a particular learning situation. Then, of course, we vary this experience with many other types of learning activities.

356. See id. at 132 ("Even the most advanced student, therefore, can deepen his understanding of concepts ... by participating in experiences all along [the] Cone.").

357. See id. at 134

A teacher may move students so swiftly to the symbolic level of thought, and with so little preparation, that their concepts will lack 
best learning occurs at the lower, more direct experience levels of Dale's Cone, nor is it the often misattributed notion that we remember more of the things that we learn from direct experience. ${ }^{358}$ Rather, the claim is that different types of learning experiences are possible and that legal teaching needs to make an intelligent use of a mix of these experiences to give students the level of understanding needed for effective learning and translation into practical application. ${ }^{359}$

These deficits of the case-dialogue method become harder to tolerate once students have acquired the legal analytical skills that the method is designed to impart. ${ }^{360}$ Indeed, there may be

deep roots in direct experience. These rootless experiences will not have the generative power to produce additional concepts and will not enable the learner to deal with the new situations that he faces.

358. Many have misappropriated Dale's Cone of Experience to present a revised pyramidal image that depicts the levels of experience with indications of the percent of information retained when learned through each approach. See, e.g., Learning Objectives, MinN. STATE UnIV. Moorhead, http://web.mnstate. edu/instrtech/SCModules/LearningObjectives/index.html (follow "Dale's Cone of Experience" hyperlink) (last visited Aug. 24, 2012) (on file with the Washington and Lee Law Review). Dale himself never attributed such percentages of retention to his Cone nor did he support the implication that experiential learning was necessarily superior to more abstract learning. See DALE, supra note 350, at 128-30; see also Michael Molenda, Cone of Experience, in EDUCATION AND TEChNOLOGY: AN ENCYClOPEDIA 161, 164 (Ann Kovalchick \& Kara Dawson, eds., 2003) (discussing the common misappropriation of the theory, noting that "[a]t some point[,] someone conflated Dale's Cone of Experience with a spurious chart that purports to show what percentage of information people remember under different learning conditions"). This misrepresentation of Dale's Cone was unfortunately featured in a recent article on legal education reform. See Sonsteng et al., supra note 286, at 309 (attributing to Dale the idea that "the least effective methods of instruction include reading text and listening to lectures," notions that Dale himself expressly disavowed in the very work cited by Sonsteng).

359. See STUCKEY ET AL., supra note 30, at 132 ("Law teachers need to be multi-modal in our teaching and reduce our reliance on the Socratic dialogue and case method. There are many tools for reaching students than one finds in the typical law school classroom.").

360. Jerome Frank estimated that students could be taught the dialectical method of legal analysis imparted by the case-dialogue method within six months, after which time other more effective methods of instruction should be used. See Frank, What Constitutes a Good Legal Education?, supra note 210, at 726

Intelligent men can learn that dialectical technique in about six months .... Teach them the dialectic devices as applied to one or two 
declining benefits associated with a continued employment of the case-dialogue method throughout the second and third years of law school. ${ }^{361}$ Thus, once this point has passed and basic foundational legal principles have been explored using the method in the first year, the pedagogy should shift toward alternative methods that help students acquire knowledge and skills in the manner and contexts that will be required of them as legal practitioners. ${ }^{362}$ In other words, a thorough understanding of legal principles and the ability to "think like a lawyer" need to become the foundation for the next step in professional development-developing the ability to handle complex problems of clients in a skilled and professional manner.

Finally, ${ }^{363}$ the case-dialogue method presents the law through the lens of litigation, most of which is appellate

fields and they will have no trouble applying them to other fields. But in the law schools, much of the three years is squandered in applying that technique over and over again to a variety of subject matters ....

See also CARNEGIE REPORT, supra note 22, at 77 (speaking of the "diminishing returns" problem in legal education characterized by the "drop-off in interest and effort in classroom learning as students move through law school").

361. See, e.g., STUCKEY ET AL., supra note 30, at 140 ("Unfortunately, many law teachers continue to rely exclusively on the Socratic dialogue and case method, not just in the first year, but also in the second and third year courses long after students become competent in case analysis and thinking like a lawyer.' This contributes to student boredom and loss of interest in learning."). This is not a new observation; Harvard students in 1935 complained that after the first year, the benefits of the case method were dramatically reduced. See STEVENS, supra note 123, at 161 ("After the first year the case method allegedly lost its value; the students thought it should be dropped or modified in the second and third years."); see also id. at 246 ("In the early 1970s, there was extensive evidence that outside those working on law review there was a dramatic falloff in energy levels and work at the end of the first year, if not in the first semester." (citation omitted)).

362. See CARNEGIE REPORT, supra note 22, at 82 ("Practice requires not the distanced stance of the observer and critic but an engagement with situations.").

363. This term is not used here to suggest that the universe of critiques of the case-dialogue method have been exhausted. Quite to the contrary, extensive critiques of the method abound. Elizabeth Mertz's work helpfully summarizes the most pertinent of these and offers an extensive argument in favor of her own critique. See MERTZ, supra note 323. One of her most incisive observations is that "thinking like a lawyer" is not a superior mode of analysis but rather is a kind of analysis that preferences certain bases for authority, modes of understanding, sources of knowledge, and types of arguments over others for 
litigation, and does so in a highly formalized and acontextual manner that skews students' perspective away from the realities and complexities of raw facts, clients, and professional responsibility. 364 The "thinking like a lawyer" modeled by the case-dialogue method often strips disputes from their context and emphasizes formal and procedural issues over other moral or personal factors that might bear on reaching a more complete appraisal of the justice of an outcome. ${ }^{365}$ Further, by being rooted in court decisions, the law is learned as the product of conflict, as a battle among adversaries that yields legal pronouncements and interpretations. But law today is not developed simply or even largely through litigation but through legislation, regulation, and negotiated agreements. These aspects of law are underappreciated in the existing curriculum, as even the bodies of law that emanate from these latter sources are studied through the eyes of court decisions interpreting them.

culturally driven reasons:

The phrase "thinking like a lawyer" is often used in a way that... characteriz[es] lawyers as possessors of an overarching and superior analytic ability rather than as experts in one profession's specialized way of processing relevant information. Like all professional epistemologies (and accompanying discourses), legal thought is socially and institutionally grounded in specific practices and power relationships. It asks some kinds of questions while neglecting others and makes sharp demands for proof in some places where elsewhere it accepts unproven assumptions. The first-year classroom is a key location for examining the shift to this particular professional language.

Id. at 98-99; see also id. at 132 ("In converting virtually every possible event or conflict into a shared rhetoric, legal language generates an appearance of neutrality that belies its often deeply skewed institutional workings.").

364. See CARNEGIE REPORT, supra note 22, at 53 ("[S]tudents tend to think of legally relevant facts as they are presented in the appellate opinions that they typically read for class discussion.... As a first encounter with legal facts, this can give the misleading impression that facts are typically easy to 'discover,' rather than resulting from complex processes of interpretation that are shaped by pressures of litigation."); see also MERTZ, supra note 323, at 95 ("[P]rofessors are conveying a linguistic ideology centered on the crucial structuring role of layers of authority, discernable in the text. Emotion, morality, and social context are semiotically peripheralized in this process.").

365. See CARNEGIE RePORT, supra note 22, at 52 (summarizing Mertz's description of an ethos "that emphasizes the formal, procedural aspects of legal reasoning as the central focus, making other aspects of cases peripheral or ancillary"). 
In the mid-twentieth century, a faculty committee at Harvard Law School described some of the benefits of the case method when it wrote:

The problems most naturally raised by reading a series of appellate cases are: Were these cases "rightly" decided? Are they consistent with one another? Can a pattern of decision be discerned that will reconcile them, even though their language is in conflict? On the basis of these decisions, how would this hypothetical case be decided? All of these inquiries are eminently worthwhile, and afford a useful training for the lawyer. ${ }^{366}$

This view is sound; the study of cases can be a worthy vehicle for learning about the law and legal analysis. However, the case method as practiced focuses on appellate opinions of judges, which do not reflect the sum total of what factored into the how particular cases were litigated or decided, ${ }^{367}$ including considerations of basic justice and fairness. ${ }^{368}$ Omitted is any consideration of the underlying record, including documents, evidence, pleadings, trial transcripts, trial court rulings, and the like, or the raw client narratives and other facts that faced the practitioner at the pre-litigation, problem-solving phase of the representation, ${ }^{369}$ in favor of a retrospective view that stymies the

366. FUlleR ET AL., Preliminary Statement, supra note 26, at 39-40.

367. See id. at 35-36

In generai American legal education with its emphasis on the appellate phase of litigation trains the lawyer in testing the validity of a position already taken, not in the problem of deciding what position to take or what course to follow.... Because law school instruction is largely based on appellate decisions, its focus is inevitably upon this last phase of a controversy, and the student receives little direct training in the choices that have to be made before this final phase is reached.

368. See MACCRATE REPORT, supra note 22, at 236

Too often, the Socratic method of teaching emphasizes qualities that have little to do with justice, fairness, and morality in daily practice. Students too easily gain the impression that wit, sharp responses, and dazzling performance are more important that the personal moral values that lawyers must possess and that the profession must espouse.

369. See FULLER ET AL., supra note 26, at 41 ("The rapid exchange of intellectual repartee that has characterized some of the best case-method instruction in the past may be excellent training for the appellate advocate, but 
development of the "legal imagination" 370 needed to develop solutions to legal problems prospectively. ${ }^{371}$ A true case method, as Jerome Frank recognized long ago, would entail a study of the entire "case" rather than the edited and refined representation of a dispute one finds in appellate opinions. ${ }^{372}$ Such an approach would permit students to assess how facts, legal doctrine, and other factors such as arguments raised, questions asked, and strategic decisions made all combined to yield a given result in one case versus another, as well as permitting them to think about how they would use the facts and the law to shape an alternate approach to the matter that might have led it down a different path entirely. Additional alternative approaches to teaching the law have been richly covered by other critics including those detailed in the 2007 Best Practices Report ${ }^{373}$ as well as in work such as Teaching Law by Design by Professors Schwartz, Sparrow, and Hess. ${ }^{374}$ However, these alternatives have not permeated the law school culture, where the legacy of the Langdellian case-dialogue method retains its sway.

it hardly furnishes the appropriate atmosphere for a discussion of the soundest solution for a practical problem of legal planning.").

370. See Rakoff \& Minow, supra note 326, at 602 (describing "legal imagination" as "the ability to generate the multiple characterizations, multiple versions, multiple pathways, and multiple solutions, to which [students] could apply their very well honed analytic skills").

371. See id. at 600

By taking a retrospective view of facts already found and procedures already used by a court, the appellate decision does little to orient students to the reality of unfolding problems with facts still to be enacted, client conduct still to take place, and procedural settings still to be chosen and framed.

372. See Frank, Why Not a Clinical Lawyer-School?, supra note 204, at 916.

373. See STUCKEY ET AL., supra note 30, at 105-234 (suggesting the use of multiple methods of instruction, including context-based instruction, to teach law school courses).

374. SCHWARTZ ET AL., supra note 320, at 107-34 (discussing a mixture of modeling, coaching, lecture, questioning, story-telling, visual-aids, and simulations to teach law school classes). 


\section{Assessment in Law School 375}

"Our machinery for checking our results [of our teaching] with you [the students] would set an intelligent ass to braying."

-Karl Llewellyn, $1930^{376}$

Karl Llewellyn, who in the above quote in no uncertain terms said that law schools put the "ass" in "assessment," recognized over sixty years ago that the traditional method of assessing student performance in law school was an ineffective means of measuring student learning. More specifically, there was and still is a gap between the professed learning objectives of many law school classes-teaching students to think like lawyers and to master certain legal doctrines-and the dominant method of measuring students' attainment of that learning-the final essay exam, which tests more so what a student knows rather than what a student can do. ${ }^{377}$ Recall that the Carnegie Report emphasized the multiple apprenticeships of professional legal education-the cognitive, the practical, and the professional/ethical. ${ }^{378}$ Becoming a competent practitioner requires training in all three areas, though-as has been discussed-law school is disproportionately oriented towards the cognitive. Thus, the single final essay exam is typically drafted in a manner that requires students to display their mastery of legal concepts and doctrines learned during the semester through the analysis of various hypothetical problems drafted by the

375. Here, I am referring to the individualized assessment of student learning. Supplemental to such assessment is the law school's assessment of its own institutional effectiveness, which can be measured in several ways. See 2011 Proposed Draft, supra note 195, Interpretation 305-2 (listing reviewing individual student assessment, evaluation of student portfolios, student surveys, student performance in capstone courses or other skills courses, bar exam passage rates, and bench and bar surveys of student performance as acceptable methods of measuring institutional effectiveness).

376. Llewellyn, The Bramble Bush, supra note 314, at 139.

377. See David P. Bryden, What Do Law Students Learn? A Pilot Study, 34 J. LEGAL EDUC. 479, 480 (1984) ("There is, then, a serious dissonance between our higher aspirations as teachers and our examination and grading practices. We aspire to teach mental habits that transcend substantive law but we do not try very hard to find out how well we are succeeding.").

378. See supra notes 257-61 and accompanying text. 
professor. These exams will either put the student in the role of a judge who must resolve a particular legal question, as an advocate who must argue in support of a particular position or decide on a course of action, or sometimes in the role of a policymaker who must decide how the law should be designed to deal with a given situation. Such questions test the students' understanding of the law and their ability to engage in proper and rigorous legal analysis.

That said, the limitations of this type of assessment are twofold. First, it is purely summative, in that it comes at the end of a course and attempts to measure learning after the course has been completed. In most courses, formative assessments-which measure student learning along the way-are underutilized or neglected entirely. ${ }^{379}$ But formative assessment is an important component of the learning process, as students need to have the opportunity to measure their understanding-or lack thereof-at a point in time when they still have the opportunity to make corrections and improvements. It is better to learn early on that one's understanding of a concept or doctrine is confused so that the lessons of the remainder of the semester can build on a solid foundation of understanding rather than simply cumulating atop confusion and uncertainty. Formative assessment is critical to coaching and guiding students through their exploration of a topic, taking care to notice when a lesson has not been fully learned and prodding them in the right direction as they proceed through the course. ${ }^{380}$ Thus, law school courses should have multiple assessment exercises along the way-graded or ungraded-that permit the instructor to determine students' learning levels and give feedback that will permit the student to adapt and improve.

Second, while typical essay exams do, to some extent, engage the analytical abilities needed of a judge or an advocate arguing a

379. Recall that unlike most law school courses today, legal instruction at the Litchfield Law School in the early nineteenth century included regular examinations every Saturday. Supra note 64 and accompanying text.

380. See CARNEGIE REPORT, supra note 22, at 164-67 (discussing criticisms of summative final exams and how students, "in the absence of feedback during the semester, [have] no basis on which to gauge whether they [are] mastering the material"). 
legal point, such skills are not the sole or principal skills required of most competent practitioners. In the litigation context, practitioners often begin with an unfiltered narrative from a client, which must be distilled into a coherent set of facts that can then be translated into potential legal claims. As an attorney proceeds with or responds to a claim, legal doctrine is not the only determinant of how the case should be litigated or of how issues that arise should be resolved. There are ethical and strategic considerations as well as intangible factors such as the profile of the parties and the judge, the nature of the claims, what happens to be at stake in the case, the relevance of issues in this case to other cases, or other larger policy concerns. All of these factors, and more, must be taken into account as an attorney decides what actions to take and what arguments to make. Engaging in this process certainly requires a good grasp of the relevant and applicable legal doctrine. But sensitivity to the full range of pertinent factors that bear on legal strategy and judicial decisionmaking takes practical experience and the development of sound professional judgment. Traditional doctrinal courses and their associated final exams tend to abstract all of these things out of legal problems, isolating doctrinal (and perhaps policy) analysis as the key to how any given issue is resolved. ${ }^{381}$ That is an unrealistic picture of most legal practice that hardly suffices to prepare a student for actual practice.

Compounding the deficiencies of summative assessments in law school is the accompanying system of grading that characterizes most law school programs. A student's grade in a course is typically determined by his or her performance on a

381. See MERTZ, supra note 323 , at 10

At the end of your first semester comes exam time. Now you have a chance to demonstrate your newly acquired legal vision of the world. In exam after exam, you are asked to respond to hypotheticals, stories made up by your professors. These stories are often replete with pathos and drama. Your job is to ignore as much of the emotional content as you can while hunting for the details that are relevant to the legal tests and frames, steadfastly averting your gaze from the human perfidy, misery, justice, or injustice found in the story. Once you've done that, if you're very careful, you can throw in a little discussion of fairness, disguised as a "policy" argument, and sometimes get some extra points. 
single final exam (perhaps with some credit or demerit for class participation), and that grade is constrained by grade normalization policies: Law schools enforce a grade distribution around a predetermined course mean (the curve). The forced distribution converts grading from an evaluation of the students' achievement to a system of ranking among course peers. The set mean-typically a $\mathrm{B}+$ or 3.3 at most elite law schools ${ }^{382}$ determines the label used to signal an average performance, divorcing traditional $A$ through $F$ letter grades from their essentialist identities (that is, $A$ is excellent, $B$ is good, $C$ is average, $D$ is below average, and $F$ is a failure) and creating an alternative, discordant world in which high letter grades are used to give a faux sense of achievement that would be absent were the traditional labels for excellent, average, and below average used. This is quintessential grade inflation. ${ }^{383}$ Indeed, the forced mean all but guarantees that the grades for all students will hover around the upper echelon; actual failures will be rare or nonexistent, ${ }^{384}$ even if a student's performance in truth reflects a failure to demonstrate proficiency with reference to the desired learning objectives for the course.

What are the problems with such an approach to grading? The principal problem is that what starts off as a poor assessment of the knowledge, skills, and values that an attorney must have to perform competently in any given situation becomes not even that; in reality the assessment is one of relative merit, ${ }^{385}$

382. See, e.g., Grading Policy, UNIv. OF Notre DAME L. ScH., http://law.nd.edu/careers/employers/policies/grading-policy/ (last visited Sept. 1, 2012) (on file with the Washington and Lee Law Review); see also List of Law School GPA Curves, WIKIPEDIA, http://en.wikipedia.org/wiki/List_of_law_school_ GPA_curves (last visited Sept. 1, 2012) (on fle with the Washington and Lee Law Review).

383. See Catherine Rampell, In Law Schools, Grades Go Up, Just Like That, N.Y. Times, June 22, 2010, at A1 (describing how several law schools have retroactively increased the mean G.P.A. in an effort to improve the students' chances with employers and the schools' reputation).

384. When there is a forced $B+$ mean, giving failing grades or $D$ grades create such a drag on the course mean that more top grades have to be given to more people, weakening the distinction between top performers and aboveaverage or mediocre performers.

385. Are there good reasons to measure relative merit from an institutional perspective? If there is a system of rewards the distribution of which depends on 
not of learning or achievement. ${ }^{386}$ That is, in a $B+$ curve grading system, an $A$ - does not represent any particular level of competence or understanding but rather is a mere indication that the student outperformed her average peers but was not among the very top performers in the class. Indeed, such a student may have been deficient in many respects in her performance on the exam, but so long as most students were even more deficient, she is able to earn the label given to those who moderately outperform, an $A$-. This grade tells an observer nothing about the student's mastery or competence in a given topical area, a fact that is dissonant with our essentialist notions of the level of quality that an $A$ - label represents. The result is that legal educators - and prospective employers - lack any true measure of the learning or capabilities of their students.

Proper assessment is about evaluating a student's attainment of specified learning objectives. ${ }^{387}$ It involves the setting of clear goals regarding what students are supposed to learn and know how to do after completing a course, followed by the administration of an instrument that measures their performance against those stated objectives. For example, in a civil procedure course, a learning objective might be that a student is able to determine whether a federal court would have subject matter jurisdiction over various claims that are asserted in an action. The assessment tool could describe the nature of certain claims asserted by a set of fictitious parties and ask for an analysis of each claim, or the exam might ask a student to take a certain factual situation and make a determination of where to assert the claims and how to respond to any ensuing

relative merit, the answer is yes. However, facilitating a reward systemwhether it be for the allocation of law journal positions or of jobs after graduation-should not yield a grading system that completely supplants a rationalized and appropriate system of assessment, the proper purpose of which is to measure achievement of learning objectives and teaching outcomes, not mere class standing.

386. See STUCKEY ET AL., supra note 30, at 237 ("The scaled grading system allows law schools to sort students for legal employers, but it impedes learning, community building, and moral development.").

387. See id. at 235 ("The main purpose of assessments in educational institutions is to discover if students have achieved the learning outcomes of the course studied." (citation omitted)). 
jurisdictional challenges. If the student were able to engage in that analysis or make those determinations correctly, the student would be entitled to be judged proficient in that area, having achieved the learning objective. A standard would have to be set for what level of success the student must achieve to warrant a conclusion that he or she was proficient in the area-perhaps based on a certain percentage of correct responses or, if the assessment instrument is more oriented toward performance, there might need to be a more qualitative standard for proficiency. With each topic or subject matter, professors would have to make ex ante determinations of what a minimum acceptable level of performance would be in any given situation; after such line-drawing, the instructor's task would be to determine whether that level was achieved or not.

Ultimately, then, what we know about proper assessmentthat it must be focused on measuring performance against clear learning objectives-points towards the development of a series of such objectives within each course, the development of formative and summative assessment measures that permit students to demonstrate their attainment of those goals, and the use of something approaching a binary or three-level ${ }^{388}$ pass-fail system that reflects achievement rather than relative merit, ${ }^{389}$ where

388. The Appalachian School of Law uses a pass-fail system that consists of the designations of "Proficient," "Not Proficient," and "Fail." Clinton W. Shinn, Lessening Stress of the $1 L$ Year: Implementing an Alternative to Traditional Grading, 41 U. ToL. L. REV. 355, 368 (2010). The problem with that approach is that the "Not Proficient" category is treated as a passing grade, even though the student is only marginally competent. Id. Further, this category is hardly a grade that will put the student in good stead with prospective employers. I would thus label not-proficient performers as failures; if distinguishing among passers is desired, "Proficient" and "Highly Proficient" categories might better serve the students.

389. There are risks to moving to a pass-fail system-particularly for nonelite law schools-which include the muddled signals employers receive about students' ability without grades. One possibility if a school is committed to using letter grades as a proxy for the pass-fail categories would be to simplify the grading system by having only $A, B+$, and $B$ - grades to reflect exemplary, proficient, and marginal performances, reserving a $C$ for failures. But it is also critical that there are ways beyond grades that students are able to demonstrate their value to prospective employers, such as with portfolios that include work done by the student and more meaningful faculty evaluations and recommendations. Of course, evaluating such qualitative materials will take 
failure is a real possibility for substandard performances. ${ }^{390}$ Rather than a single final essay exam, doctrinal courses should be characterized by a series of opportunities for formative assessment-graded or ungraded-consummated by a summative evaluation designed to mirror more closely what will be expected of a student once he enters practice and confronts such situations. ${ }^{391}$ That means that not only is analytical ability and facility with doctrine assessed, but also students' ability to gather, interpret, and present facts or to assess a situation to determine what action should be taken to achieve a particular goal for one's client. Quizzes, problems, and other meaningful

more effort and commitment on the part of employers who may be accustomed to relying on grades as simple proxies for merit.

390. See Shinn, supra note 388 , at 369 (explaining that at least $15 \%$ of students in 1L classes at Appalachian School of Law must receive grades of "Not Proficient" or "Fail," but that professors are not required to give any grades of "Fail"). Therefore, for this system to be meaningful, a "Fail" or "Not Proficient" grade would have to be real, meaning that professors were willing and able to assign that grade to students whose performance fell short of a predetermined level of sufficiency. Although other disciplines such as medicine exhibit less hesitation in awarding failing grades to students, law schools are institutionally averse to failures, which is likely for at least three reasons.

First, it may be that an $F$ grade is seen as deserved only for a complete lack of knowledge or competence-scoring near zero percent correct if you willrather than as being appropriate for poor performances that include instances of lucidity-let us say a $60 \%$ or $50 \%$ performance.

Second, because of the forced mean, if an $F$ grade is given to a student, many very high grades must be given to offset the downward pull such a grade has on the class average. For example, in a class of ten students, it would be mathematically impossible to give more than one student an $F$ grade if the required mean were $B+$ or a 3.33; even if eight students were given $A$ grades, giving the remaining two students $F$ grades would result in a mean of 3.2 [( $8 \mathrm{x}$ $4.0+2 \times 0) / 10=3.2]$.

Finally, failures mean that courses must be repeated, a consequence that law schools are not designed to accommodate in large numbers. Further, were students to regularly be subjected to failing grades across courses, they would have to leave the law school. Such attrition, were it to be of a significant number of students, would not be consistent with the business model of most law schools, which rely on maintaining a certain level of enrollment to support their budgets.

391. See 2011 Proposed Draft, supra note 195, Standard 304 (showing that a revision to the American Bar Association Standards recently under consideration would require law schools to "apply a variety of formative and summative assessment methods across the curriculum to provide meaningful feedback to students"). 
assignments along the way will help the professor gauge students' understanding and progress throughout the term. ${ }^{392}$

Although achievement-based assessment and grading is preferred, enforced means are an important tool for equalizing grades across courses taught by different professors who may have varying views of what level of performance deserves a given grade. A similar problem could arise under a pass-fail system, where different professors reach different judgments about what level of performance is necessary to demonstrate proficiency in a topical area. However, enforcing a mean across all courses is not the solution to this problem because of the impact such means have on moving assessment away from being an evaluation of achievement against learning goals towards a system that signals relative merit. A more appropriate solution would be to have learning objectives and determinations of proficiency levels centrally or collectively determined. ${ }^{393}$ That is, a law school would-either through a group of professors ${ }^{394}$ who teach the same subjects or collaboratively among relevant professors and administrators-be responsible for setting and/or scrutinizing the learning objectives identified by professors and for setting or approving of the standards for proficiency and distinctiveness applied to all assessment instruments, rather than leaving such determinations solely to the discretion of the individual professor. The professor would certainly be the originator of these standards and should have a say in their ultimate form. However, there must be collective agreement across the faculty regarding these matters to ensure that a performance that earns a "pass" in one course would not earn a "fail" in another course. As setting such standards for achievement is an inherently subjective process,

392. For a fuller discussion of more effective assessment methods in legal education, see SCHWARTZ ET AL., supra note 320, at 135-63; STUCKEY ET AL., supra note 30 , at $235-63$.

393. See 2011 Proposed Draft, supra note 195, Standard 302 (showing that a revision to the American Bar Association Standards recently under consideration would require law schools to "apply a variety of formative and summative assessment methods across the curriculum to provide meaningful feedback to students").

394. If this would not be the province of any existing law faculty committee, perhaps a new "assessment" or "institutional standards" committee could be established. 
doing so collectively across different types of courses will be challenging. ${ }^{395}$ But such an approach is superior to the blunt instrument of an enforced curve because it makes assessment and grading a measure of substantive versus relative achievement, something that is much more meaningful and the true mark of quality assessment in education.

Finally, it must be acknowledged that forced means also are a bulwark against substandard professor instruction, which might result in many students being deficient in their knowledge in part due to the failures of the professor. If a modified pass-fail or simplified letter-grade system is pursued, professors would have to use more formative assessments with feedback to make sure that their students were learning and progressing along the way. They would also need to make sure that the final assessment is properly calibrated to measure what was successfully taught and learned during the course. That said, there would be no guarantee that student performance would collectively rise to the proficient level. Under such circumstances, the professor's teaching abilities would have to be evaluated but so too would the content and pace of the educational program being delivered to the students to make sure that it is commensurate with their aptitude to learn.

\section{Law School Faculty}

"How can we expect law students to become competent practitioners if the core of full-time law faculties, notwithstanding its scholarly prowess, does not itself possess even the basic skills required to practice the type of law about which it teaches and writes?"

-Brent E. Newton, $2010^{396}$

395. Within a particular subject, one could imagine the possibility of having school-wide, standardized exams for the basic required courses that are graded by a common rubric. This would make grade normalization more rational across different sections. However, such an approach would require each professor to cover the same material in the same courses, which would impinge on individual professors' freedom to select areas of emphasis.

396. Brent E. Newton, Preaching What They Don't Practice: Why Law Faculties' Preoccupation with Impractical Scholarship and Devaluation of 
As we have seen, Langdell introduced the idea that full-time academics with little or no experience were to be preferred when staffing a law school faculty. ${ }^{397}$ More or less true to this vision, contemporary law school faculties are dominated by tenured and tenure-track professors who are less experienced practitioners than they are highly credentialed legal scholars. ${ }^{398}$ Traditional doctrinal law faculty currently maintain an obligation to contribute in the areas of teaching, scholarship, and service, ${ }^{399}$ carrying a typical teaching load of three to four courses per year ${ }^{400}$ and being expected to produce scholarly publications on a regular basis. 401 In return, this category of professors is highly compensated, ${ }^{402}$ in an effort to attract the most highly

Practical Competencies Obstruct Reform in the Legal Academy, 62 S.C. L. REV. 105, 147-48 (2010).

397. Supra notes 103-08 and accompanying text.

398. See infra note 407 and accompanying text (providing data on the average practice experience of law professors).

399. See, e.g., Lewis \& Clark College Faculty Handbook, LEWIS \& CLARK CoLL., 50 http://www.lclark.edu/live/files/10303-faculty-handbook-section-1--5 (last visited Sept. 2, 2012) ("To receive tenure, a faculty member must demonstrate excellence in teaching, scholarship, and service ....") (on file with the Washington and Lee Law Review).

400. In 2006, Jennifier Collins, at Wake Forest University School of Law, posted a request regarding teaching loads at law schools, to which there have been multiple comments suggesting loads in the three to four course range, also articulated in credit hours per year as anywhere from nine to twelve credit hours. Jennifer Collins, Teaching Loads, CoNCURRING OPINIONS (Dec. 11, 2006), http://www.concurringopinions.com/archives/2006/12/teaching_loads.html (last visited Sept. 2, 2012) (on file with the Washington and Lee Law Review); see also Gordon Smith, Law Professor Teaching Loads, The Conglomerate, http://www.theconglomerate.org/2005/04/law_professor_t.html (last visited Sept. 2,2012 ) (providing information on teaching loads from 2005) (on file with the Washington and Lee Law Review).

401. See, e.g., University of Richmond Faculty Handbook, at Appendix: The T.C. Williams School of Law Personnel Policies and Procedures, Standards and Procedures for Reappointment, Promotion, and Tenure, UNIV. OF RICHMOND, http://facultyhandbook.richmond.edu/Ch_VI/law.html\#tenure (last visited Sept. 3 , 2012) ("As part of the application for promotion from Associate Professor to Professor and for the award of tenure, the applicant must submit at least four published scholarly works of high quality.") (on file with the Washington and Lee Law Review).

402. The Chronicle of Higher Education reports that for the 2010-2011 school year law professor salaries were the highest of all disciplines, varying positively $59.5 \%$ above the average full-time professor of English language and 
credentialed and most capable scholars to a school. Why is hiring expensive, inexperienced high-quality legal scholars important to the modern American law school? As the Carnegie Report explains:

Within academic circles, legitimacy and respectability accrued to whatever could be assimilated to the model of formal, science-like discourse.... Since the coin of that realm is productivity in scholarship and research, it is not surprising that law schools have increasingly emphasized this dimension of their faculties' work and identity. ${ }^{403}$

Certainly, hiring in this manner is instrumental to achieving a mission oriented toward producing legal scholarship, which

literature, compared with a 50.9\% figure for business school professors and $41.2 \%$ for economics professors, the next two highest paid disciplines. Faculty Salaries Vary by Institution Type, Discipline, THE CHRONICLE OF Higher EDUCATION (Apr. 11, 2011), http://chronicle.com/article/Faculty-Salaries-Varyby/127073 (last visited Sept. 12, 2012) (on file with the Washington and Lee Law Review). Although information about salaries at private law schools is difficult to obtain, salary information for several public law schools is available online. Salaries at these schools vary widely, from $\$ 90,000$ to over $\$ 300,000$. See, e.g., Paul L. Caron, Public Law School Faculty Salaries, TaxProf Blog (Aug. 19, 2011), http://taxprof.typepad.com/taxprof_blog/2011/08/public-law.html (last visited Sept. 12, 2012) (on file with the Washington and Lee Law Review). Dean Erwin Chemerinsky noted that when he was being recruited to become the Dean of the newly created University of California, Irvine School of Law, he initially rejected the proposed salaries for the Dean and the faculty, explaining as follows:

[T]heir proposed dean's salary was about half of what I was earning as a professor at Duke Law School, and ... their top faculty salaries were about at the level of entry-level faculty hires. I was clear that I would not be interested in the position if that were the level of funding. I was candid that the law school could not be very good on the proposed budget.

Chemerinsky, supra note 24 , at 1 . Chemerinsky was ultimately hired at a salary of $\$ 350,000$. See Comm. on Compensation, Appointment Salary for Erwin Chemerinsky as Dean, DoNALD BREN ScH. OF L., IRVINE CAMPUS, http://www.universityofcalifornia.edu/news/compensation/chemerinsky0907.pdf. Faculty salaries at U.C. Irvine School of Law were reported as ranging from $\$ 131,200$ to $\$ 199,300$ in 2009 , with summer research grants amounting to oneninth of one's salary. Univ. of Cal., Irvine, Professor Series-Law School Academic Year Rates (Oct. 1, 2009), http://www.ap.uci.edu/salary/CurrentScales/ prof-Law.pdf.

403. CARNEGIE REPORT, supra note 22, at 6-8. 
many, if not most, law schools embrace. ${ }^{404}$ More cynically but no less verily, the U.S. News \& World Report ranking system, ${ }^{405}$ with its heavy emphasis on peer reputation, ${ }^{406}$ makes it critical that law schools attract and retain a faculty regarded as productive of high quality scholarship if they wish to maintain or enhance their position in these standings.

Are law faculties - as currently constituted —up to the task of delivering the balanced, integrated curriculum suggested by the 2007 Carnegie Report? Unfortunately, there are two main problems with relying on traditional law professors of this mold to deliver a revised curriculum. First, as just mentioned, traditional doctrinal professors are not typically hired for their practice experience, of which they tend to have little ${ }^{407}$ or

404. See, e.g., Mission of the Law School, UnIV. OF Chicago Sch. OF L., http://www.law.uchicago.edu/school/mission (last visited Sept. 2, 2012) ("Since its founding in 1902, a major component of the University of Chicago Law School's mission has been to develop and disseminate knowledge through scholarly research that critically analyzes the development of the law and related disciplines.") (on file with the Washington and Lee Law Review); see also Mission and Vision, UNIV. OF ST. ThOMAS ScH. OF L., http://www. stthomas.edu/law/missionvision/ (last visited Sept. 2, 2012) ("The law school will... participate in the improvement of legal institutions and other organizations through recruitment and development of a faculty of outstanding teachers and scholars, sponsorship of academic lectures and interdisciplinary research activity, and establishment of a strong law library collection and staff.") (on file with the Washington and Lee Law Review).

405. See U.S. News \& World Report, Best Grad Schools 70-76 (2013), available at http://grad-schools.usnews.rankingsandreviews.com/best-graduateschools/top-law-schools/law-rankings (providing rankings and general information on law schools in the United States).

406. Under the methodology used by U.S. News \& World Report, "peer assessment score"-a rating by key figures at other law schools of the quality of the school in question-accounts for $25 \%$ of a school's overall score. Robert Morse \& Sam Flanigan, U.S. News \& World Report Law School Rankings Methodology, U.S. NEwS \& WORLD REPORT, http://www.usnews.com/education/ best-graduate-schools/articles/2011/03/14/law-school-rankings-methodology2012 (last visited Sept. 2, 2012) (on file with the Washington and Lee Law Review).

407. See Redding, supra note 293, at 601 (showing that for those law professors hired between 1996 and 2000, of those with any practice experience (86.6\% of the hires), the average number of years of experience was 3.7). A 1991 study found that all law professors at that time had an average of 4.3 years of practice experience, with the experience of hires at law schools ranked in the top 25 being only 1.4 years. See Robert J. Borthwick \& Jordan R. Schau, Note, Gatekeepers of the Profession: An Empirical Profile of the Nation's Law 
none. ${ }^{408}$ Rather, law professors are hired mostly based on their academic credentials and their promise as legal scholars. ${ }^{409} \mathrm{~A}$ corps of instructors thusly qualified is not ideally suited for delivering a curriculum of expanded practical experiential learning, ${ }^{410}$ and arguably is not optimal for practice-oriented, doctrinal instruction, ${ }^{411}$ meaning that adjuncts or differently

Professors, 25 U. MICH. J.L. REFORM 191, 218 (1991). One commentator's informal study of law professors hired between 2000 and 2009 revealed an average of 1.79 years at U.S. News \& World Report-ranked tier one schools but 7 years at tier four schools. See Newton, supra note 396, at 130.

408. See Newton, su pra note 396 , at 130 (“45.6\% of entry-level, tenure-track professors hired by [tier 1] schools since 2000 had no prior practical experience."); see also Harry T. Edwards, The Growing Disjunction Between Legal Education and the Legal Profession, 91 Mich. L. REv. 34, 37 (1992) ("The situation is even worse now . . . because now we see 'law professors' hired from graduate schools, wholly lacking in legal experience or training ...."). It is not unusual for elite law schools to hire law professors with no practice experience, although such hires tend to have doctorates in another field in addition to their law degrees. See, e.g., Northwestern Law Faculty Research \& Achievement, NORTHWESTERN UNIV. SCH. OF L., http://www.law.northwestern.edu/faculty/ (last visited Sept. 13, 2012) ("Together, our faculty members combine to form what is, we believe, the most eclectic and balanced mix of legal scholars among our nation's law schools.") (on file with the Washington and Lee Law Review). Indeed, Northwestern University School of Law touts having the highest percentage of $\mathrm{PhD}$-trained full-time faculty members (47\%) of all American law schools. Id.

409. Columbia Law School advises its students interested in an academic career as a law professor as follows:

[G]etting excellent grades at a distinguished law school, being a law review member or (preferably) officer, and having a prestigious clerkship after graduation have been the most important factors [that make one a good candidate for a teaching job], especially at the top schools. In recent years, however, scholarly achievement-not just potential-is increasingly required .... Most law faculties still value candidates who have practiced law, so a few years of experience... can be useful.

Almost Everything You Need to Know About Law Teaching, ColumBIA L. ScH., http://www.law.columbia.edu/careers/law_teaching/Everything (last visited Sept. 13, 2012) (on file with the Washington and Lee Law Review).

410. See Newton, supra note 396, at 147 ("Because practical skills ... are honed by significant practical experience, it is highly unlikely that most tenuretrack professors-particularly the new breed of interdisciplinary theoreticianscould effectively teach such a course.").

411. See CARNEGIE REPORT, supra note 22, at 196 ("Both doctrinal and practical courses are likely to be most effective if faculty who teach them have some significant experience with the complementary area."). 
viewed clinical faculty have to pick up the slack. Second, traditional law faculty members are expensive from the perspective of the law school, as their salaries account for a large share of a law school's budget ${ }^{412}$ and tend to be impervious to dramatic reductions. ${ }^{413}$ Transforming law school to a system that involves much greater skills training and a decrease in courses taught through the large-class Socratic case-dialogue method would require much smaller faculty-student ratios, a proposition that would be quite expensive if the hiring of additional traditional faculty were the means undertaken to achieve that goal.

How, then, can law school faculties hope to offer an improved curriculum? Some schools might favor relying on the heavy use of adjunct professors for practice-oriented courses, given the meager wages generally paid to such instructors. ${ }^{414}$ This is a sub-optimal

412. See Jack Crittenden, How Legal Education Is Changing, Albeit Slowly, THE NAT'L JURIST (Jan. 12, 2012), http://www.nationaljurist.com/content/howlegal-education-changing-albeit-slowly (last visited Sept. 3, 2012) ("[T]he single biggest cost in legal education is ourselves. When will salaries do [sic] down and tenure [be] abolished?" (quoting Dean Jim Chen of the University of Louisville Brandeis School of Law)) (on file with the Washington and Lee Law Review).

413. See, e.g., Jon Ralston, UNLV President Presents Cuts, Says They Are "A Tragic Loss and a Giant Step Backward for Nevada," LAS VEGAS SuN, Mar. 8, 2011, http://www.lasvegassun.com/blogs/ralstons-flash/2011/mar/08/unlv-presidentpresents-cuts-says-they-are-tragic-/ (last visited Sept. 2, 2012) (sharing a spreadsheet showing that out of over $\$ 47.5$ million in budget cuts, zero was to be cut from law school salaries) (on file with the Washington and Lee Law Review). University of Nevada, Las Vegas's law school intended to cover these budget cuts with tuition increases instead of faculty cuts. See Erwin Chemerinsky, Invest in Higher Education, L.A. TIMES, Dec. 27, 2010, http://articles. latimes.com/2010/dec/27/opinion/la-oe-chemerinsky-uc-tuition-20101221 (last visited Sept. 3, 2012) (discussing that by "[p]aying significantly less than other schools ... the best faculty will leave and those with other choices will not come. The quality of teaching and research will steadily decrease [making it] ever harder to attract excellent students and faculty") (on file with the Washington and Lee Law Review); see also Univ. of Nev., Board of Regents Briefing Paper, 1 (June 16-17, 2011), http://www.scs.nevada.edu/tasks/sites/Nshe/assets/File/ BoardOfRegents/Agendas/11/june/main/BOR-10.pdf (requesting 19.5\% and 4.5\% increases to resident and non-resident law student tuition, respectively).

414. Adjunct professors at law schools tend to earn "a four-figure stipend" for teaching a class. Katherine Rosman, The Ultimate Power Hobby, WaLL ST. J., Sept. 30, 2010, http://online.wsj.com/article/SB1000142405274870411600457552 1800478591046.html?mod=WSJ_hps_sections_lifestyle (last visited Sept. 2, 2012) (on file with the Washington and Lee Law Review). 
solution, however, because adjuncts are typically unable to give the time and attention necessary to provide high quality experiential instruction to students compared with properly qualified full-time instructors dedicated to such courses. ${ }^{415}$ Further, the ABA Standards strongly discourage the use of adjuncts in the first-year curriculum and provide that "full-time faculty shall teach the major portion of the law school's curriculum," 416 while also requiring that full-time law school employees be the supervisors of all clinics. ${ }^{417}$ That said, adjuncts can and must have some role in delivering experiential learning given the reality of limited resources; the perfect scenario (using all full-time faculty) should not be made the enemy of the good scenario (using adjuncts), and the ABA standards should be revised to permit a greater role for part-time faculty or adjunct instructors. Another possibility would be to expand the ranks of clinical faculty in proportion to the rest of the faculty. Their salaries typically are lower than traditional doctrinal faculty, ${ }^{418}$ but their reach in terms of numbers of students is more limited given the small size that clinics must be to be effective.

Ultimately, schools interested in moving their curriculum in a more practice-oriented direction will have to give serious thought to revising their hiring patterns to identify experienced

415. This differential flows largely from the fact that adjuncts will have other full-time employment that will not necessarily accommodate the need to dedicate large amounts of time to supervising law students and they are not physically located at the law school where they would be more readily accessible to their students. See id. Adjuncts may also be less experienced in teaching than full-time faculty and, thus, may do a poorer job, although this is hardly a universally true. Full-time faculty members are not necessarily outstanding classroom teachers guided by the latest research on effective pedagogy nor may they be qualified to guide students through simulations of practice scenarios they have not themselves experienced.

416. 2012-2013, ABA STANDARDS AND Rules OF PROCEDURE FOR APPROVAL OF LAW SCHOOLS, supra note 28, Standard 403(a).

417. Id. Standard 304, Interpretation 304-3(e).

418. For example, the highest-paid clinical faculty person at the University of North Carolina, Chapel Hill School of Law had a salary of $\$ 101,000$ in 2011, lower than the $\$ 110,500$ salary paid to several Assistant Professors. University of North Carolina, Chapel Hill Public Salaries, Collegiate Times, http://www.collegiatetimes.com/databases/salaries/university-of-north-carolinachapel-hill-2010?dept=Law (last visited Sept. 14, 2012) (on file with the Washington and Lee Law Review). 
practitioners who have the potential to be great classroom teachers. ${ }^{419}$ Although scholarly potential could remain a factor, exalting that above the ability to deliver practice-relevant training and experiences to students would not be sensible if this type of curricular reform were the goal. To be clear, this is not a goal all law schools may want to embrace; law schools should be free to pursue a variety of missions, including serving as a preeminent center of scholarly research on the law. But for those schools wishing to emphasize a mission of preparing students for practice, hiring differently-meaning a shift toward more experienced lawyers - will have to be part of the equation. ${ }^{420}$

\section{$V$. The Next Century in Legal Education}

What have we learned? The four pillars of law school education-its curriculum, its pedagogy, its mode of assessment, and its faculty - all have roots in the Langdellian reforms of the late nineteenth century. The justification for the design of the Langdellian law school-that law is a science best learned from studying "original sources" at the feet of masters of learning rather than masters of practice - has been called into question ever since that time, but the basic model has endured. Its resilience seems to be linked to a variety of factors: The consonance of the Langdellian model with faculty backgrounds and aspirations makes it fairly self-perpetuating; the economics of the approach have been heretofore unquestionably superior to more effective alternatives; students and employers have historically been unresponsive to law school curricular reform as

419. A 1980 report of the ABA Special Committee for a Study of Legal Education recommended "the law school recruitment process for full-time faculty increasingly look to the practicing segment of the profession for its potential faculty members." AM. BAR ASS'N SPECIAL COMM. FOR A STUDY OF LEGAL EDUC. supra note 165, at 105.

420. Jerome Frank made a similar proposal to expand practice-experienced faculty many years ago. See Frank, Why Not a Clinical Lawyer-School?, supra note 204, at 914 ("A considerable proportion of law teachers in any law school should be men with not less than five to ten years of varied experience in the actual practice of law."). 
they continue to prioritize school prestige ${ }^{421}$-not the quality of training-in making enrollment and hiring decisions; 422 and the deficiencies of the approach were less consequential in a world in which the bar understood and fulfilled its duty to complete the training of lawyers during their first couple years of practice.

Unfortunately, the fraying of the foundation for the justification and perpetuation of the Langdellian model is not likely to usher in fundamental change with ease. Law faculty benefit from the current structure of the course delivery system and may be loath to take on work that will compromise time for other pursuits or impose burdens without increasing compensation. ${ }^{423}$ Further, the profile of current law faculty-

421. See NALP, AFTER THE JD, supra note 5, at 79 (reporting survey results that "indicated that two credentials are crucial to finding the first job after law school: the reputation of the school and law school grades"); see also Sloan, supra note 9 ("The most prestigious law schools still dominate when it comes to placing graduates."); Leichter, supra note 17, ("Why aren't California's more price-sensitive firms hiring grads directly from the People's College of Law in Los Angeles rather than from UCLA . . . ? Firms could do this but instead, they prefer ABA grads from highly regarded law schools.").

422. See, e.g., MACCRATE REPORT, supra note 22, at 6-7 ("[F]ew employers appear interested in whether students have enrolled in [skills] courses or how they perform in them."); id. at 7 n.2 ("The American Bar Foundation survey of hiring partners found ... that this selection of particular courses has little or no impact on hiring decisions."). This stubborn fact, that legal employers complain about the quality of legal education but do not alter their hiring patterns in response to law school reforms, is a major contributor to the complacency among many legal academics, particularly at elite schools. This commitment to credentials-law school ranking and class ranking-as the determiners of hiring decisions means that doing a better job of training lawyers for practice receives little reward, at least in the short term. As a result, there is less incentive to pursue such reforms, at least among top-tier schools, particularly to the extent they raise the cost of legal education or place cherished school rankings at risk. That said, the competition for students among such schools is fierce, particularly in an environment of declining Law School Admission Test (LSAT) takers. See David Segal, For 2nd Year, a Sharp Drop in Law School Entrance Tests, N.Y. TIMES, Mar. 19, 2012, at B1 ("In all, the number of test takers has fallen by nearly 25 percent in the last two years."). To the extent that curricular and other reforms can attract more and better students to one's school, an increasing number of elite schools may begin to pursue reforms over time.

423. As Upton Sinclair once observed, "It is difficult to get a man to understand something, when his salary depends upon his not understanding it!" UPTON SINCLAIR, I, CANDIDATE FOR GOVERNOR: AND HOW I GOT LICKED 109 (Univ. of Cal. Press ed. 1994); see also David Segal, What They Don't Teach Law Students: Lawyering, N.Y. TIMES, Nov. 19, 2011, at A1 ("Professor Rubin failed 
having been educated under the Langdellian system and having had little to no practice experience-renders them less sympathetic to the urge toward practice-relevance and less competent to devise and deliver a program with such an orientation. ${ }^{424}$ This point was apparent to Jerome Frank, who long ago lamented that inexperienced teachers who learned only the law in books-the so-called "book lawyer" or "library-law teacher"-controlled law schools and, thus, could thwart the reform process:

Unfortunately, attempted reform of legal pedagogy is frequently in the hands of the "library-law" teacher. With the best will in the world, such a teacher often finds it almost impossible to warp over the old so-called case-system so as to adapt it to the needs of the future practicing lawyer. For, as above noted, that system is centered in books. So long as teachers who know nothing except what they learned from books under the old case-system are in control of a law school, the actualities of the lawyer's life are likely in that school to be considered peripheral and as of secondary importance. ${ }^{425}$

Perhaps focusing on the "law in books" was appropriate in a time when students would go on to learn the "law in action" during the first years of practice; academic legal education was originally meant to precede and supplement law office training, not supplant it. ${ }^{426}$ Because that tandem relationship between the two spheres has shifted-from formal, to informal, to optional, to nonexistent-law schools must reform the Langdellian model to fill the void.

to sell his faculty members on a retooled first-year Contracts class. 'Some members of the faculty got a little overstressed by all the change.").

424. See John Lande \& Jean R. Sternlight, The Potential Contribution of $A D R$ to an Integrated Curriculum: Preparing Law Students for Real World Lawyering, 25 OHIo ST. J. DisP. REsol. 247, 274 (2009)

[M]any law faculty members tend to have "conservative" attitudes about reform. Law professors often value tradition. It is not unusual for faculty to believe that the law school curriculum worked well for them when they were law students and that it should work well for current law students as well.

425. Frank, Why Not a Clinical Lawyer-School?, supra note 204, at 915.

426. See supra notes 57-60 and accompanying text. 
What should that reform look like? I have sketched out some thoughts above-that schools should give some consideration to expanding practical skills training, 427 diversifying pedagogical methods, developing more meaningful assessment techniques, and considering the benefit that more experienced practitioners could bring to a law school faculty-but these and other ideas require much more thorough treatment than $I$ have given them here and will have to await future work. ${ }^{428}$ Further, beyond law school, there are other improvements that need to be made in the areas of pre-law education, ${ }^{429}$ bar admissions standards, ${ }^{430}$ and continuing legal education while in practice.

427. A survey of judges by Judge Richard Posner and Professor Albert Yoon revealed the opinion that "law schools should provide more course work oriented to instilling practice-oriented skills." Richard A. Posner \& Albert H. Yoon, What Judges Think of the Quality of Legal Representation, 63 STAN. L. REV. 317, 338 (2010-2011).

428. That said, the work of the Best Practices Report, the Carnegie Report, and those focusing on pedagogy such as Professors Schwartz, Sparrow, and Hess in Teaching Law By Design, provide a solid vision of the direction legal education needs to take going forward. See generally ScHWARTZ ET AL., supra note 320; CARNEGIE REPORT, supra note 22; STUCKEY ET AL., supra note 30. Washington University law professor Brian Tamanaha has also offered some suggestions for the future, including giving schools the flexibility to pursue differing objectives, such as a research-orientation or a practice-orientation, which will result in their faculties having different backgrounds. See BRIAN Z. TAMANAHA, FaILING Law Schools 173-80 (2012).

429. See HARNO, supra note 23, at 127 ("Many of the problems of legal education owe their being to deficiencies in the pre-legal period."); see also MACCRATE REPORT, supra note 22, at 230 ("Most prelaw counseling takes place only after individuals have already decided to become lawyers . . . . The need for advice at an earlier time in the decision-making process is apparent.").

430. See, e.g., HARNO, supra note 23, at 155 ("[T]he bar examiners [should] introduce examinations, in addition to those they now give, to test applicants for admission on their proficiency in the simpler skills of the profession."); see also REPORT OF THE TASK ForCe ON THE FUTURE OF THE LEGAL PROFESSION, supra note 21, at 68-69 (recommending that "the New York State Board of Bar Examiners begin assessing professional skills"). California has long had a practice component to its bar exam. See Kristin Booth Glen, Thinking Out of the Bar Exam Box: A Proposal to "Maccrate" Entry to the Profession, 23 PACE L. REv. 343, 410-11 (2003) (detailing the parts of the 1980 California Bar Experiment that were adopted as part of the California bar exam). More recently, a Multistate Performance Test (MPT) has been developed as part of the Uniform Bar Exam (UBE), in an effort to universalize performance evaluation in the bar admissions process. See Uniform Bar Examination (UBE), NAT'L CONF. OF B. EXAMINERS, http://www.ncbex.org/multistate-tests/ube/ (last visited Sept. 9, 
But our concern here has been the Langdellian model of law school education. If that model is fundamentally broken-a question that will likely remain the subject of great debate ${ }^{431}$ then only fundamental change will do, rather than the incremental change we have seen over the past 130 years. Fundamental change means rethinking our categorization of doctrinal subjects and commitment to them as the dominant component of training for legal practice.432 It means acknowledging what other disciplines seem to know about how people learn, and giving in to the need to bring that knowledge into our own classrooms. ${ }^{433}$ It means going beyond traditional classroom dynamics and physical libraries to approaches that leverage technology to deliver content while focusing face time on meaningful discussions and problem solving. ${ }^{434}$ It means making the effort to evaluate students against learning objectives in a way that measures and supports their growth and development. It means opening our minds to the notion that using experienced lawyers to educate novice lawyers-in-training is not some radical proposition, but an approach that bears a greater promise of

2012) (describing the different elements of the Uniform Bar Examination) (on file with the Washington and Lee Law Review).

431. Although there may be clear deficits with contemporary approaches to legal education, the question is whether these fundamental problems adversely affect law school graduates in an enduring manner or do the deficits simply wear off over time as graduates gain experience through legal practice. If the latter is the case, one could argue that this is a short-term problem for each individual that does not warrant an overhaul of how we train lawyers.

432. For example, should we continue to teach contracts, property, torts, criminal law, and civil procedure in the first year or should we be teaching American legal system, introduction to the common law, transactional law, business law concepts, American public law, transnational law, constitutional rights, and civil litigation?

433. For example, having students learn by doing, in context, more so than learning by reading and hearing alone.

434. See generally THOMSON, supra note 7 (discussing how technology can be leveraged to improve legal education); see also Robert Talbert, Thoughts on the Culture of an Inverted Classroom, CASTING OUT NINES (May 25, 2011, 8:23 AM), http://chronicle.com/blognetwork/castingoutnines/2011/05/25/thoughts-on-theculture-of-an-inverted-classroom/ (last visited Sept. 15, 2012) (discussing "inverted classrooms," in which lectures are offered online and classroom time is used for discussion, working on problems, and helping individual students) (on file with the Washington and Lee Law Review). 
inculcating students with the tools they need for practice. It means freeing law schools to focus on their respective missions and areas of strength, rather than playing to a unitary, Harvardbased model of legal education. ${ }^{435}$ And it means that legal employers-who complain incessantly about the quality of legal education-will have to start putting their jobs where their mouths are, hire based more on the quality of training received than on one's class rank and school prestige, ${ }^{436}$ and reclaim some responsibility for the continuing education of their new hires. ${ }^{437}$

435. This was one of the key observations of Alfred Reed in his 1921 Carnegie Foundation report on law school. See REED REPORT, supra note 1, at 417-18 ("Attempts by each type of law school to carry the entire burden of legal education produce such unsuccessful results as to bring the entire body of practitioners into disrepute."). Of course, to realize this end, some reform would have to take place in the U.S. News \& World Report ranking system, which ranks all law schools along a single scale. Perhaps moving toward the approach U.S. News takes with undergraduate rankings - categorizing them as national universities, national liberal arts colleges, regional universities, and regional colleges-would be something that could be tried for law schools. Unfortunately, no law school is likely to embrace the label "regional law school" or "local teaching law school."

436. A promising area for future research would be to examine the hiring patterns of employers across and within law schools over time to see if there has been any migration towards job applicants with more extensive practical training; if not, the question of what they truly value in a potential hire-versus what they say they value-arises.

437. Something else employers could consider would be to hire new associates at dramatically reduced pay and offer them extensive practical training experiences, akin to the apprenticeship model used in other countries such as Canada ("articling") and England ("pupilages" for barristers). See supra notes 195-96 and accompanying text. Some American law firms have experimented with this approach, although the model has not become widespread. See Elie Mystal, Howrey First Years to \$100K, ABove THE LAW (June 22, 2009, 3:26 PM), http://abovethelaw.com/2009/06/howrey-first-years-to$100 \mathrm{k} /$ (last visited Sept. 3, 2012) ("[Howrey] is moving to more of an apprenticeship model. New Howrey associates will receive an emphasis on training and take a significant reduction in salary.") (on file with the Washington and Lee Law Review); see also Elie Mystal, Salary Cut Watch: Drinker Biddle Cuts Salaries AND Rates, ABove The Law (May 11, 2009, 4:22 PM), http://abovethelaw.com/2009/05/salary-cut-watch-drinker-biddle-cuts-salariesand-rates/ (last visited Sept. 3, 2012) ("Rather than immediately assign the incoming lawyers to client matters, [Drinker Biddle] will enroll its hires in a new training program that will provide courses on taking depositions, writing briefs, and meeting client needs.") (on file with the Washington and Lee Law Review). Howrey was dissolved on March 15, 2011. See Brian Baxter, Howrey to Dissolve Effective March 15, AMLAW DaIly (Mar. 9, 2011, 5:45 PM), 
Many readers will want a bit more specific advice regarding legal education reform than I have given here. I will thus offer some reforms that a law school wanting to do a better job of preparing its students to become practitioners could undertake:

- Modernize the first year to include an introductory overview of the legal system and the legal profession, as well as subjects more pertinent to contemporary legal practice such as transnational law and administrative law;

- Impose a live-client experience requirement, having all students participate in either a clinical course or an externship;

- Extend legal research and writing education into the second year, featuring more extensive simulation training focused on certain areas such as litigation and transactional skills;

- Redesign the content of traditional courses away from an emphasis on cases toward more source material and practice documents, while redesigning the delivery of courses around more group work and problem-solving exercises in the lawyer role during class meetings;

- Hire full-time, part-time, and adjunct faculty who can bring more extensive and contemporary practice experience to bear on the design and delivery of the curriculum;

- Develop capstone courses that enable third-year law students to synthesize their learning across courses and apply it in practice settings.

These are not steps that all law schools must take. Rather, these are simply some possibilities that some schools could consider; there are surely other ways to improve the ability of legal education to prepare students, and schools should be free to

http://amlawdaily.typepad.com/amlawdaily/2011/03/howrey-partners-vote.html (last visited Sept. 3, 2012) (on file with the Washington and Lee Law Review). Drinker Biddle carries on with its program. See First Year Associate Development Program, DRINKER BIDDLE, http://www.drinkerbiddle.com/ careers/Summer\%20Associates/First-Years (last visited Sept. 3, 2012) (outlining the details of their first year associate development program) (on file with the Washington and Lee Law Review). 
pursue them. Further, while the above reforms may be worthwhile improvements, work remains to be done that can demonstrate their efficacy in better preparing students for practice, at least sufficiently to justify the cost and potential disruption that might accompany some of these efforts.

Unfortunately, several external constraints facing law schools make fundamental reforms difficult to embrace: ABA standards limit the ability to use active practitioners as part-time faculty, require the commitment of extensive resources to physical libraries, and limit the amount of distance education that students can apply toward their degrees; the U.S. News rankings lump all schools into a unitary system that rewards things like expenditures per student, faculty scholarship and prestige, and LSAT scores rather than qualities that relate more directly to a school's ability to prepare its students for practice; and bar exams continue to focus almost exclusively on substantive knowledge rather than practice competency, a focus that law schools must mirror to some extent if their graduates are to be able to pass the bar. Hopefully over time these and other external factors will evolve in ways that facilitate the more effective legal education that reformers have been urging for the past century.

\section{Conclusion}

Traditional legal education remains bound up with many of the fundamental attributes designed by Langdell at Harvard Law School more than a century ago. It is a decidedly academic, or cognitive, model of legal education - centered on legal doctrine and case law-with varying degrees of elective opportunities to attain practical and professional competence. To be truly effective, however, professional legal education must give more attention to transmitting the skills and values that are essential compliments to doctrinal instruction. Mastering the cognitive, practical, and ethical dimensions of legal practice are what professional legal education must be about; focusing largely on the law in books cannot do the job. Perhaps the late (and great) Derrick Bell said it best when he wrote the following: 
By... giving priority to "learning by doing" simulations, students mimic the kind of process that an attorney, researching an unfamiliar area of law, might utilize to investigate prior decisions. In practice, lawyers are called to research and to write; to comprehend legal arguments; to guess at the probable effect of and interaction between judicial, statutory, legal and policy arguments in court; to argue, persuade and debate; to work cooperatively with colleagues; and for some, to judge those arguments and decide cases and issues of law. This is as true in the practice of constitutional law as in any other. Once their research skills are in place, most students are aware that they have the capacity to learn, relatively quickly, whatever they need or want to know regarding any legal question. ${ }^{438}$

This full range of abilities gained through experiential learning is what law schools should strive to deliver if their goal is to produce competent attorneys. Students need to learn how to "work like a lawyer," not just how to "think like a lawyer." 439

This has been understood by many since the time of Langdell, as evidenced by the continual criticism emanating from the ABA, the Carnegie Foundation, and legal commentators since the late nineteenth century. What makes change possible now is that the unprecedented confluence of disintermediation ${ }^{440}$ in the legal profession, the stagnation of incomes in the legal job market, a bubble in law school tuition and attendant student borrowing, and the prospect of a decline in law school applications and enrollments that will require all but perhaps the most elite and secure law schools to innovate or die. I have no doubt that many law professors will react to these admonitions much as most law professors have reacted to previous efforts to

438. Derrick Bell, Constitutional Conflicts, 21 Seatrte U. L. Rev. 1039, 1044-45 (1998).

439. Zandt, supra note 31 , at $1133-34$

The excellent legal analysis and advocacy skills that are the hallmark of law school programs must remain an essential element of legal education, but today's law students also need a much more sophisticated understanding of what it means to work as well as think like lawyers in their multi-job careers.

440. See Susskind, supra note 12, at 6 ("Lawyers, like the rest of humanity, face the threat of disintermediation (broadly, being cut out of some supply chain) by advanced systems ...."). 
improve legal education-with denial or sighs of impossibility or indifference-given the many obstacles to reform. ${ }^{441}$ It may require bold leadership from deans to make the case for a new vision of legal education and an insistence on the adoption of certain measures, perhaps as a condition of their taking on or continuing to serve in the dean role. ${ }^{442}$ Certainly, there may be faculties that take the lead in responding to the need for significant change. However we get there, it is clear that we need to get beyond the Langdellian model toward a truly twenty-first century program of professional legal education that prepares graduates for practice; the time is ripe for getting there if we can all collectively muster the will to take the first steps.

441. See Schwartz, supra note 340 , at 360 ("The legal academy's policies regarding law school hiring, promotion, and tenure practices, law school textbooks, law school accreditation practice, and law school economics have created an environment in which change is very unlikely to occur.").

442. Brian Tamanaha has suggested just such an approach in his "Dean's Vision" speech, in which he announces pay cuts and increased course loads as norms that would characterize his deanship if hired. See Brian Tamanaha, My "Dean's Vision" Speech, Balkinization, (Nov. 16, 2010), http://balkin.blogspot. com/2010/11/my-deans-vision-speech.html (last visited Sept. 1, 2012) (on file with the Washington and Lee Law Review). 


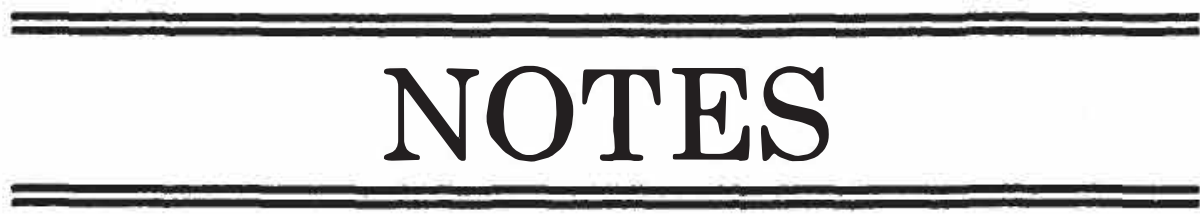

